Historic, Archive Document

Do not assume content reflects current scientific knowledge, policies, or practices. 

EASTER, 1900.

No. 6.

\title{
Southern Californía
}

\section{Acclimatizing Hssociation}

\author{
SANTA BARBARA. CALIFORNIA, U.S.A.
}

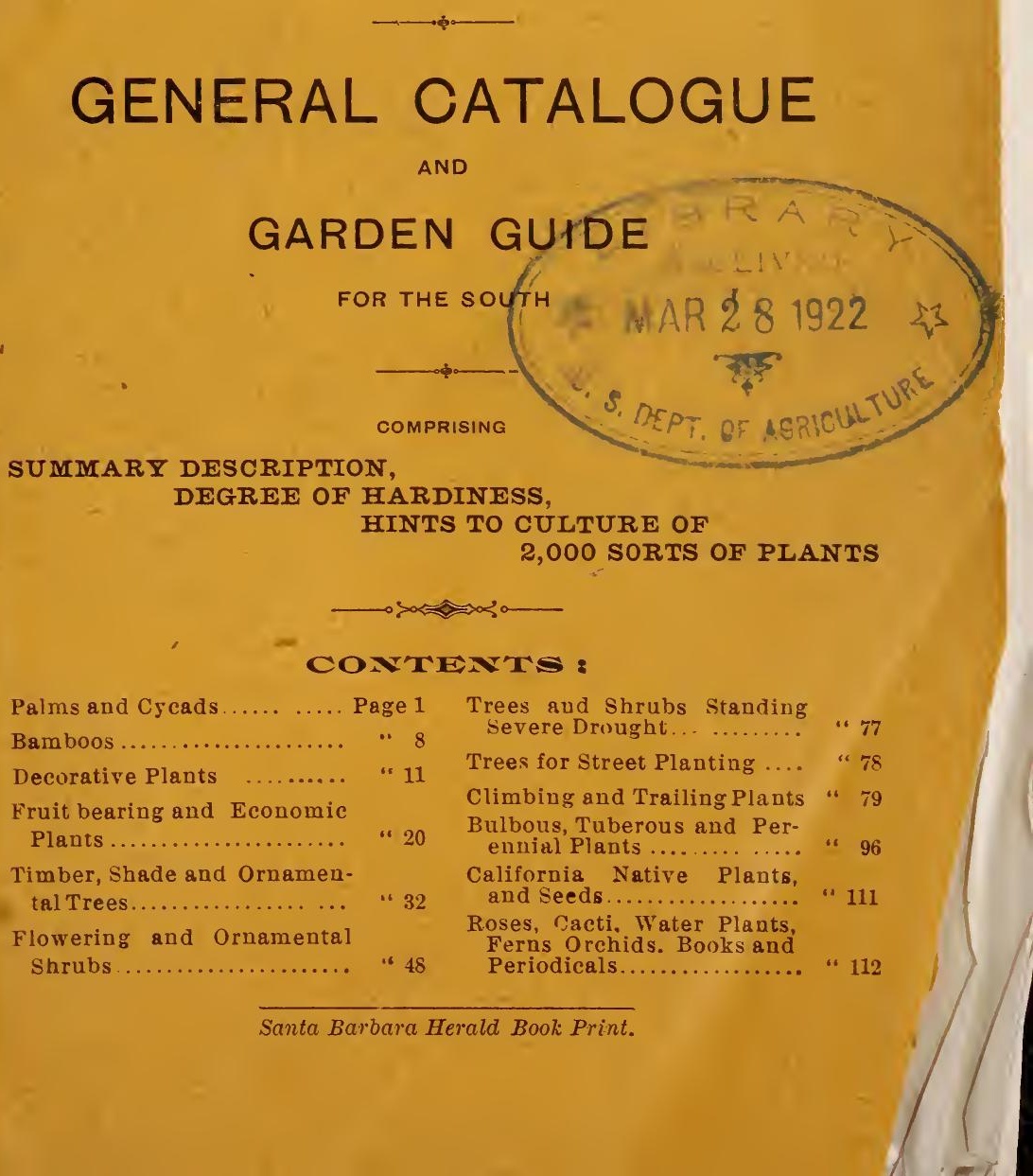




\section{To Our Friends at Home and Abroad:}

T $\mathrm{T}$ has been our ambition to make the most of the exceptional advantages of Santa Barbara, where climatic conditions allow to grow to perfection, and in remarkably short time, plants from almost every country.

How far we did succeed is shown in plain flgures by this new edition of our GENERAL CATALOGUE: never before such extensive selection of plants has been offered for sale in the United States, a large number of them being of our own introduction. The native habitat of each plant is given, and in addition its degree of hardiness is nuted in reference to some generally known standards.

Popular and reliable books on horticulture are scarce in this country, and much information concerning plants is sought for in Catalogues of Commercial Establishments: what is contained in ours is true and correct, so that it may be used as a trustworthy reference book.

To all Patrons and Friends we wish to extend our sincerest thanks for past favors, and solicit their continuation. Through the hearty co-operation of all persons interested in horticulture we will be enabled to continue in our work of introducing and testing all sorts of plants having economic or ornamental value, and to build up a distributing center here, for which purpose no other locality is better adapted.

Our Catalogue comprises selections of the most desirable plants, but we can furnish also any other plant not mentioned there in it, if obtainable in the trade.

Our terms are STRICTLY CASH II ITH ORDER.

Parties ordering Plants are requested to specify way of shipping they prefer.

Correspondence to be addressed,

P. O. BOX 1500,

SANTA BARBARA, GaL., U. S. A.

SOUthern CaLIFornia ACCLIMATIZING Association. DR. F. FRANCESCHI, Manager.

\section{PLEASE READ THIS.}

Names printed in CAPITALS are of plants first offered by us in the United States.

* Denotes plants to be grown safely in open ground where the LEMON can be grown.

** Denotes plants adapted only to practically FROSTLESS localities.

For remaining plants the APRICOT may be taken as a standard; some will eudure more cold, as will be specified. 


\section{The Zapote= Blanco.}

S

OUND and vigorous, although nearly a centenarian, the pioneer of exotic trees introduced into California stands in the very heart of Santa Barbara, on West De la Guerra street, two blocks from State street. Casimiroa edulis (this being its botanical name) is a native of Sonora and other temperate regions of Mexico, and belongs to the order of Rutaceae, which comprises also the co-called "Citrus fruits." It has a huge warty trunk, dense spreading crown, evergreen trifoliate leaves, and bears small greenish flowers followed by globular yellow fruits, very sweet, and endowed with very remarkable narcotic power, so that they are said to be used in Mexico for the treatment of insomnia. Our tree, most likely a seedling, happens to bear very small fruits, which probably accounts for its not having been more widely propagated. A few feet only from the tree, almost hidden among the weeds, the foundations are to be seen of an adobe building where Colonel Fremont established his powder magazine in the early times of the occupation of California. In the absence of an appropriate tablet, the large Zapote watches as a sentinel these old memorials, a much older evergreen memorial itself. (See next page.) 


\section{PALMS AND CYCADS.}

Universally acknowledged to be the noblest and most prominent ornament in gardens, PALMS will have their beauty constantly increasing with age. Their multiform economic uses are indeed beyond enumeration, but considered only as ornamental plants, their adaptability to different purposes is unsurpassed; from the decoration of windows, halls and jardinieres to the building of stately avenues and picturesque groves. Palms are naturally distributed all over the tropics of both hemispheres, with a few representatives in temperate regions, some of which will stand many degrees of frost. Most Palms will thrive better in full sun, some will prefer partial shade; rich soil and plenty of water when growing are desirable; but there are not a few, like the common Date Palm and other kinds of Phœnix, the California fan Palm, Chamaerops humilis, and others, that will thrive in rocky and dry places without irrigation. CYCADS, although distinct from Palms in organic structure, partake of the same characteristics as ornamental plants, and are horticulturally classified with them.

**Acrocomia sclerocarpa, West Indies........\$

The "gru gru" Palm, or "corojo," having fine spines on trunk, leaves and fruits.

*Archontophoenix Alexandrae, Queenslanà....

Commonly known as Ptychosperma Alexandrae, or "Alexandra palm," similar in habit to the following, but more stately and attaining larger size. 
*Archontophoenix Cunninghamii, East Australia\$

Nore known as seaforthis eleyaus; one of the most elegaut and free-growiug palms. Our plants are raised from seed ripeued in Sauta Barbara.

**Areca Aliciae, Queensland................

**Areca glandiformis, India................

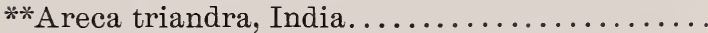

All of them very graceiul, feathery, medium sized Palms; rather tender.

**ARENGA ENGLERI, Formosa...........

Probably hardier than the following

**Arenga saccharifera, Moluccas.............

'Tne "guinuti palm," yieldiug sugar and strong fiber; Irusas silvery underueath.

**Attalea cohune, South Mexico and Guatemala the "Coquito or ralma de Aceite" the fruits of which are expurtedin large quantities for soap making; froads staudiug erect and over 30 feet high.

*BRAHEA DULCIS, Mexico..............

Tne Palma dulce, with edible fruits, growing at high elevatiuns.

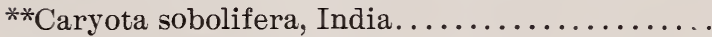

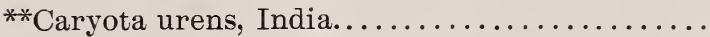

Popularly known as fish tail Palms, from the way the segments of their frouds are cut.

${ }^{*}$ Chamaedorea desmoncoides, Mexico..........

A climbing species with dark greeu foliage, will do better in partial shade.as generally all Chamaedoreas

*Chamaedorea elatior, Mexico..............

Tne tallest of the genus, making rapidly large clumps, very ornumental.

*Chamaedorea Ernesti Augusti, Mexico........

*CHAMAEDOREA GEONOMAEFORMIS,



*CHAMAEDOREA NEC PLUS ULTRA?

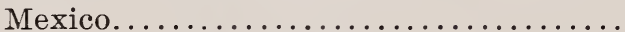
Most elegant dwarf species, similar in habit to Cocos Weddeliaua but much hardier.

*CHAMAEDOREA OBLONGATA, Mexico.... *CHAMAEDOREA SARTORI, Mexico........ *CHAMAEDOREA TEPEJILOTE, Mexico..... All the above are graceful dwarf kinds, blooming quite young, the flowers, stalk and pedicels being of scarlet color; will make admirable pot and window plauts. 
*Chamaerops Birroo, China ?..............\$

Chamaerops humilis, South Europe and North

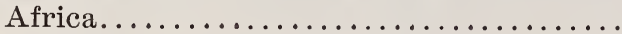

One of the hardiest palms, growing very compact and suitable for small lawns.

*Chamaerops Cochinchinensis, Cochinchina?... 50

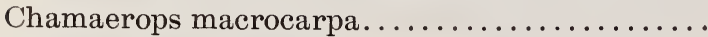
50

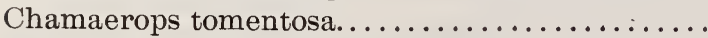

Probably only forms of $\mathrm{Ch}$ humilis.

**Chrysalidocarpus lutescens, Mauritius........

The correct name for "Areca" lutescens, one of the prettiest and most elegant palms for house decoration, with light green leaves and golden yellow stems.

*CLINOSTIGMA MOOREANUM, Lord Howe's

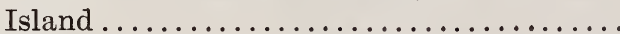

Commonly known as Kentia Moorei, being the dwarf. estamong Kentias.

${ }^{*}$ COCOS ACAULIS, Brazil................

*COCOS AUSTRALIS, Uruguay.............

The true species, unt to be confused with C. eriospatha; habit and fronds in the line of C. plumosa, but more slender and dwarfer.

*Cocos campestris, Brazil................ .

*Cocos coronata, Brazil.................. 100

*COCOS COMOSA, Brazil................ 100

${ }^{*}$ Cocos Datil, Southern Brazil............. $\quad 50$

Probably the most graceful among its congeners of the temperate zone.

COCOS ERIOSPATHA, River Plate.........

The most hardy of all Cocos and one of the hardiest paims; fronds bluish, gracefully arching; fruit pulp tasting like apricots. Commonly kn own as C. Australis, under which name also other kinds are grown.

${ }^{*}$ Cocos flexuosa, Southern Brazil .... .......

Similar in habit to C. plumosa, but with more finely cut leaves, and in Southern Europe considered to stand more frost.

${ }^{*}$ COCOS GLAUCA, Brazil ..................

*COCOS ODORATA, Brazil .................

*Cocos plumosa, Southern Brazil . .

This has been and is the most extensively planted in Santa Barbara, where there are specimens over 35 feet high; trunk slender, smooth. whitish as well as the leaf stalks. 
${ }^{*}$ Cocos Romanzoffiana, Southern Brazil . . . . \$

similar to the preceding, but with fronds standing more erect: fruit edible, called "geriva."

*COPERNICIA WRIGHTII, Cuba .........

A moderate size fan palm with broad leaves used for thatching.

${ }^{*}$ Corypha gebanga, Java ................

A stately fan palm attaining large size; has proved quite hardy at Santa Barbara.

**Dictyosperma album, Mauritius. . .........

**Dictyosperma rubrum, Mauritius ..........

Commonly known as Areca alba and Areca rubra, both making very pretty hoise plants; the first with leares veined pure white, the second with crimson.

**DYPSIS species, Madagascar. ..........

A new undetermined species closely related to the preceding.

Erythea armata, Lower California...........

The striking "blue palm" known also under the names of Brahea glauc:a and B. Rnezli; probably the most glaucous of palms; will prefer rocky soil, and will stand some degrees of frost.

Erythea edulis, Guadalupe Island.............

More rapid grower than the preceding, and one of the finest and hardiest fan palms. Trunk slender, 30 foet and more high; leaves broad. bright green. with woolly petioles; blnoms quite young. bearing a wonderful profusion of large, round fruits turning black at maturity, and edible.

*ERYTHEA sp. nova, Sonora ? ............ A new undetermined species, dwarfer and more graceful than the preceding; fruits corered with waxy substance.

**Euterpe edulis, Brazil ... .............. The "Assai palrn." of Para, making a pretty ornamental house plant.

*Hedyscepe Canterburyana, Lord Howe's Island

Known also as Kentia Canterbursana or "umbrella palm," is the tallest growing of the five different palms found nnly in that serlnded island; will prefer partial shade and plenty of moisture when growing.

*Howea Belmoreana, Lord Howe's Island. ...... *Howea Forsteriana, Lord Howe's Island .......

More known as Kentia Belmoreana and K. Forsteriana; no doubt the most popular of house palms, and deservedly so; both will prefer partial shade, if planted out.

*Hyophorbe amaricaulis, Mauritius..........

A stately palm with deep green leaves, orange midrihs and maronn stems. 
*Hyophorbe Verschaffelti, Rodriguez Island....\$

This has gracefully arching fronds veined with white, and makes an easily grown and not delicate house plant.

Jubaea spectabilis, Chili.

.0 to 500

One of the most hardy pulms, can endure drought and many desrees of enld: if liberally treated will grow fast ennugh, and build huge trees in " few years, Fruits are called "coquitos" and look like a diminutive cocoanut.

**Latania Commersoni, Mauritius. ... . . . . . .

* Latania Loddigesii, Round Island

Both highly ornamental dwarf fan palms, the first hoving red-margined, spiny leaves, the second glan cous green leaves.

*Livistona australis, East Australia

25 to j 00

Known iu gardens also as Coryphu australis, one of the most nopular and hardy house palms; will stand slight frosts: beautiful specimens with slender trunks and dense srown of dark green fronds are to be seen in Santa Barbara, Los Angeles and San Diego.

*Livistona chinensis, Southern China.

Ifore generally known under the wrong name of Latasia Borbonica, similar to the preceding and even more used for house plant: will ieed partial shade when planted out.

*LIVISTONA JENKINSIANA. Assam ........

A most handsome species, living at ennsiderable altitude iu the Himalaras.

*LIVISTONA MARIAE, Queensland ........

Newly introduced, the young leaves beautifully tinged with red.

**Livistona rotundifolia, Java

Dwarf growing; makes very graceful house plants.

**ONCOSPERMA FASCICULATUM, Ceylon. .

Growing in the style of the prettiest Arecas.

**Oreodoxa oleracea, West Indies ... ........

The "cabbage palm" attaining in favorable conditions 170 feet; a very fast grower; in some places cut \&own for the central tender ieaves or cabbage when only three years old.

**:Oreodoxa regia, Cuba

The "palma real," and well named, too, for its stately beauty: trunk slender, smooth, white, attaining over 100 feet.

*Phoenix Canariensis, supposed to be a garden

hybrid.

Perhaps the most popular and most easily grown of all palms, and too well known to deserve description. 
*Phoenix dactylifera, North Africa..........\$

25 to 500

The common date palm, of which a very large number of varieties exist, and some may be profitably grown in the south. Not very oruamental in the young state, but hardly to be sirpassed in mature age.

*Phoenix farinifera, India................

Verycompact growing and ornamental, with shining dark green fronds.

*PHENIX HANCEANA, Southern China .....

A most graceful dwarf kind recently discovered, and to our knowledge never before offered in the trade.

"Phoenix humilis, Formosa ?.............

Very distinct and graceful, with bluish leaves.

*PHCENIX JUB $\mathbb{E}$, Teneriffe... . . ... ....

Closely related to the common date, and apparent $1 \mathrm{y}$ peculiar to the Canary islands.

*Phoenix pumila, Southern China........... Another dwarf growing kind, most suited for house decoration.

*Phœnix reclinata, South Africa.............

Quite ornamental for its slender trunk, orange colored leaf stalks, and gracefully arching fronds generally hanging hedge ways.

*Phœnix rupicola, Himalaya...............

This has become quite popular of late years. and is indeed a most graceful and desirable palm, chiefly for house decoration.

*Phœnix sylvestris, India... ............ .

Yielding toddy or palm wine, very vigurous and spiny.

"Phœenix zeylanica, Ceylon

Dwarf and very pretty.

**Pritchardia Gaudichaudi, Hawaiian Islands. . *PRITCHARDIA MARTII, Hawaiian Islands

A very rare species, growing much larger than the preceding.

**Pritchardia pacifica, Fiji Islands .........

Three magnificent fan palms, having a peculiar appearance of their own.

**Pseudophœenix Sargenti, extreme Southern Florida.......................

The choicest palm we offer, and very likely not grown by anybody else at present, the original trees being exceedingly limited in number and bearing seeds very sparingly.

Rhapidophyllum hystrix, Florida........... Known also as Chamaerops hystrix: the short trunk thickly beset with hlack hristies. 
${ }^{*}$ Rhapis flabelliformis, Japan............\$

A most graceful dwarf palm growing in thick dark green clumps, a very good house plant; will preter partial shade if planted out.

*Rhopalostylis Baueri, Lord Howe's Island. .....

*Rhopalostylis sapida, New'Zealand...........

Known also as Areca Baueri and A. sapida:two feachery leaved palms, the first growing larger and having broader pinuae.

*Sabal Blackburniana, Bermuda...... .....

*Sabal Ghiesbreghti, Mexico ... ..........

*Sabal Mexicana, Southern Texas and Mexico. .

Sabal Palmetto, Carolina to Florida...........

*Sabal umbraculifera, West Indies. . . . . . . . . . .

All Sabals belong to the fan leaved section of palms, but showing in their leaves the transition to the pinnate leaved section, as very prominent in S. Palmetto, the most kuown and hardiest of them all.

*SERENOA ARBORESCENS, extreme Southern

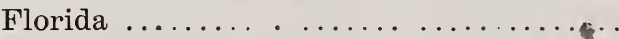

Discovered quite lately; truuk tall and slender; leaves glaucous; young plants appear to be quite fasi growers.

Serenoa serrulata, Florida.

100

วั0 to ว 00

亏0

50

25

ธั0

The saw-palm or saw-palmetto, a dwarf growing palm, of which the cut up heads are much used for decoration.

Trachycarpus excelsus, China.............

The correet name for Chamaerops excelsa, or Chusan palm, no doubt the most hardy of all palms, fast growing and easily transplanted; makes also an excellent house plant.

*Thrinax argentea, Florida..............

*Trithrinax brasiliensis, Brazil............

Considered to be one of the most graceful fan paims; leaves dark bluish green.

Washingtonia filifera, California............

Our well known California fon palm, unsurpassed to be sure wherever immediate effect is required.

W ASHINGTONIA SONOR $Æ$, Sonora and Lower California....................

Recently discovered and apparently quite distinct from the above. 


\section{CYCADS.}

*CERATOZAMIA MEXICANA, Mexico......\$

Trunk stout; fronds dark green.

*Cycas circinalis, India . . . . . . . . . . . .

A magnificent species; fronds much longer than C. revoluta.

*CYCAS NORMAMBYANA, New South Wales Discovered a few years agu, very fine and rare.

*Cycas revoluta, China and Japan. .........

The so-called "sugo pulm," a tine decorative plant for small lawns, terraces, etc.

*Dioon edule, Mexico....................1 00 to 1000

One of the fiuest aud choicest cycads, to be used as the above.

*DIOON SPINULOSUM, Mexico............

A very rare kind, differing from the preceding mostly in having its pinuse inargined with sharp points.

* Macrozamia spiralis, Australia...........

Very choice and remarkable; loug feathery fronds twistiug in spiral shape:

*ZAMIA ANGUSTIFOLIA, Bahamas .......

*Zamia integrifolia, Florida..............

Both pretty, dwarf kinùs, looking like dimiuutive iycas revoluta.

\section{BAMBOOS.}

Both on the utilitarian and on the ornamental standpoint hardly any other plants will compete with Bamboos in enriching a country and in beautifying the landscape, if introduced on a large scale. Their wonderfully varied uses, from a tender vegetable or pickle, to the building of houses, 
are known to everybody, but it is not generally known that in our Southern States many of the so-called "giant bamboos" can be profitably grown, and that no other plant will increase and propagate more freely. The Chinese and Japanese kinds mentioned below will endure many degrees of frost. The rich deep alluvial soil of our valleys will particularly suit Bamboos, but it would be a mistake to believe that they will grow only in moist grounds, many of them being in fact ordinarily exposed to very severe droughts in their native countries.

Arundinaria Fortunei, Japan ............. \$

Dwarf, spreading. about oue foot high; leaves beauti-

fully variegated, the white predominating.

Arundinaria Hindsii, China and Japan. .

15 feet or more, narrow, grass-like leaves and upright

brauchlets, giving it quite a peculiar appearance.

Arundinaria Japonica, Japan............. .

10 or 12 feet, with thin, weak stems and broad leaves; desirable as a decorative plant in cold sections, as it can stand many degrees of frost.

Arundinaria macrosperma, Southern Atlantic

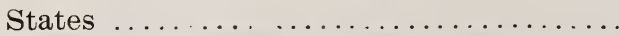

There forming the so-called "canebrakes," attaining over 18 feet in favorable conditions, a small, hardy kind, with elegant foliage.

ARUNDINARIA NOBILIS, Himalaya? ......

Said to attain large size; same feathery habit of $B$. gracilis.

Arundinaria Simoni, Northern China.........

Attaining 20 feet in deep, moist soil; thin stems with permanent shealhs; leaves beautifully variegated; one of the hardiest kinds.

*BAMBUSA ARUNDINACEA, India........

The spiny bambon of Bengal, will attain 70 feet in favorable conditions, and over four inches in diameter.

*Bambusa gracilis, Himalaya..............

A most graceful kind not over 18 feet high, with thin glancous stems and a mass of feathery foliage, admirably suited for lawns and for decoration.

**BAMBUSA ORIENTALIS, India..........

Close to $B$. arundinacea, making rapidly beautiful clumps; leaves larger and velvety to the touch, being covered with very fine silky hair. 
Bambusa pubescens? Japan.............. .\$

Bambusa quadrangularis, Japan.............

The celebrated square-stemmed bamboo,exceedingly curious and interesting but of smail size.

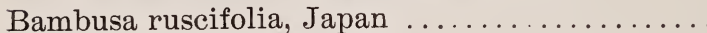

Quite dwarf and pretty, suitable for rockwork, also for growing in pots.

Bambusa scriptoria, Himalaya?. ............

*Bambusa verticillata? fol. var. Himalaya?....

15 to 20 feet, stems orange vellow, leaves in whorls striped with white.

*Bambusa vulgaris, India...............

Not spiny, attaining 70 feet in favorable locations, and over 4 inches in diameter.

*BAMBUSA VULGARIS AUREO STRIATA. .

A variety of the preceding; golden yellow stems striped green: a striking plant.

*BAMBUSA VULGARIS? var. TAISAN ...2 250 to 500

Perhaps a distinct species altogether, grown in Japan but not native there; columnar shape like a Lombardy Poplar; stems up to 4 inches in diameter; leaves broad, cark green, a truly magnificent species.

${ }^{*}$ BAMBUSA N. I., Japan .... ... ........

Another "giant bamboo" with sheaths beautifully striped white and glaucous green; apparently hardier ihan other "giants."

*BAMBUSA N. II., Japan... . . . . . . . . . . .

Very distinct; stems upright, 15 feet or more, perfectly cylindrical with no groove; branches short. all of same leugth; a great runner.

BAMBUSA N. III., KAN-CHIKU in Japanese.

Very peculiar looking; only four to $5 \mathrm{f}$.; stems very thin, appearing in the fall, said to be much prized in Japan as "winter greens."

**DENDROCALAMUS M E MBR A N A CEUS,

Burmah ..................... 100 to 250

A vigorous growing kind, said to attain large size.

**Dendrocalamus strictus, Himalaya..........

50 to 60 feet high, and about 3 inches in diameter.

Phyllostachys aurea, Northern China .........

100 to 250

25 to 100

About 12 feet high, stems golden yellow, very thickly jointed at the base.

PHYLLOSTACHYS BAMBUSOIDES, Japan. .

Not over 12 feet high; stems thin, but very strong; formerly used for arrows. 
PHYLLOSTACHYS CASTILLONIS, Japan and

China ...................... \$ 25 to 100

30 feet and over; stems yellow striped green; leaves striped pale yellow.

PHYLLOSTACHYS HENONIS, J a p an and

China ...................... 25 to 100

PHYLLOSTACHYS HETEROCYCLA, Japan. 100 to 250

A very queer looking species; stems up to two inches, snort jointed, knots alternate in opposite directions.

PHYLLOSTACHYS MARLIACEA, Japan ....

Phyllostachys mitis, Northern China ... ....

This is the giant of this section of hardy bamboos, attaining 60 feet, and over 2 inches in diameter.

Phyllostachys nigra, Northern China.........

In this the mature stems, 15 feet high or so, will assume a beautiful jet black color.

Phyllostachys nigra punctata, Northern China. .

A variety of the preceding; stems black, spotted with yellow.

PHYLLOSTACHYS SULPHUREA, Japan ... Stems thin, sulphur yellow; stands drought better than others.

Phyllostachys viridiglaucescens, Northern China 25 to 100

50 to 200

25 to 200

100

50 to 100

25 to 250

To be sure the best of the hardy kinds, stems deep green turning to yeliow, not much over 1 inch but attaining nearly 40 feet in favorable conditions. All bamboos of this section are very hardy and will send out-runners in every direction, so that they will cover a large area of ground in very short time.

Thamnocalamus Falconeri, Himalaya.........

Known also as Arundinaria falcata, much resembling B. gracilis, but smaller and more spariugly leaved.

**THYRSOSTACHYS SIAMENSIS, Burma and

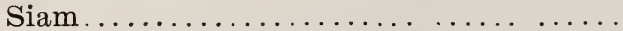

Another "giant bamboo" very handsome; rather tender.

\section{DECORATIVE PLANTS.}

Under this heading are comprised plants other than Palms and Bamboos having bold and striking foliage, which 
can impart conspicuous and attractive features in gardens or in houses, independent of flowers, although in some cases these may be quite remarkable and showy. These are rather a promiscuous lot, and will need different treatment as specified for each of them. All Agaves, Nolinas, Yuccas and so forth, mostly natives of the arid regions of our Southern States and Northern Mexico, will grow in the dryest places without irrigation at all, but will amply repay any more liberal treatment bestowed on them.

Agave americana, Mexico............... 25 to 200

Agave americana, yellow bordered........ 25 to 200

Agave americana, yellow striped.......... 25 to 200

*Agave americana, yellow patched........ 50 to 200

The commonly called "century plant" with its different varieties invaluable indeed for rough use.

*AGAVE ATtenuATA, Mexico...........

Building a slender trunk with broad glaucous metallic shining leaves of soft texture; a very remarkable plant.

*AGAVE BUFFARDI, Mexico?...........

*AGAVE CARIBAEA, Martinique..........

*AGAVE DECIPIENS, Florida .............

Tall growing, leaves dark green.

Agave deserti, California .................

A bluish, compact growing kind, rather rare.

*Agave Engelmanni, Mexico...............

Dwarf elegant, introduced quite recently.

*AGAVE EXCELSA, Mexico ..... .........

AGAVE FEROX, Mexico .................

Large growing; deep green leaves rhombiform with formldable red spines.

Agave filifera, Mexico ...................

Dwarf, growing in hemispherical tufts; edges of the leaves splitting in white filaments.

AGAVE FRANZOSINI, Mexico?............

Large growing, of peculiar blue color, very striking.

*Agave geminiflora, Mexico..............

Leaves rush like, very tender green.

*AGAVE GHIESBREGHTII, Mexico........

Compact dark green, with formidable spines. 
*Agave Gilbeyi, Mexico.................\$

Emerald green, maroon spines.

AGA VE HORRIDA, Mexico................

Horrific indeed for its fierce spines.

*AGAVE KEWENSIS, Southern Mexico ......

Very distinct; leaves emerald green.

AGAVE MEXICANA, Mexico. .

Leaves narrow, glaucous, standing upright, stveral f. long; very decorative.

*AGAVE MITIS, Mexico.................

Leaves light green laying flat, with small, hardly notice able spines.

Agave Palmeri, Arizona..................

Forming a low rosette, glaucous, spines red.

*AGAVE POTATORUM, Mexico............

Large growing,the best for the production of "pulque"

*Agave recurvata ? Florida... ............

Greyish blue in color, leaves gutter shaped bending down; very ornamental.

*Agave rigida Sisalana, Yucatan.............

Now extensively planted in Florida and the Bahamas. yielding the well-known "sisal hemp."

*AGAVE ROVELLIANA, Garden hybrid? ....

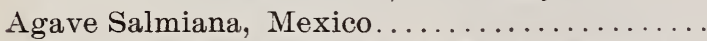

One of the largest growing Agaves, leaves deep green; hardier than $d$. Americana.

*Agave Shawi, Lower California

Compact growing, deep blue color, red spines.

*AGAVE STRIATA GLAUCA, Mexico.......

Leaves glaucous shaped like a porcupint quill.

AGAVE UTAHENSIS, Utah and California... .

Growing more north than any other Agave,very hardy

*Agave Victoriæ Reginæ, Mexico ........... 00 to 1000 Quite distinct and very choice species.

*Aloe africana, South Africa..............

*ALOE ELEGANS, South Africa............

*Aloe frutescens, South Africa.

*ALOE GRACILIS, South Africa........... $2 \tilde{0}$

*ALOE HANBURYANA, South Africa.......

*ALOE LATIFOLIA, South Africa.........

25 to 200 $2 \tilde{5}$

*ALOE MACROCARPA, South Africa........

*Aloe saponaria, South Africa... ..........

25 to 100 
*Aloe Socotrina, Socotora island...........\$

*Aloe variegata, South Africa..............

All the above Aloes are moderate sized plants with exception of A. frutescens, growing quite tall; they are eminently adapted for rockeries as well as for house plants; bear bright orange or scarlet flowers, and will stand the roughest treatment.

Arundo donax, var., Southern Europe ........

White striped variety of the tall common reed, so ex. tensively planted in California.

*Beaucarnea glauca, Mexico...

50 to 500

Crown of stiff, glaucous leaves on slender trunk, bottle shaped at the base.

*Beaucarnea recurvata, Mexico.............

Similar to the above, with bright green, gracefully drooping leaves.

*BESCHORNERIA DECOSTERIANA, Mexico

*BESCHORNERIA SUPERBA, Mexico.......

*BESCHORNERIA TUBIFLORA, Mexico.....

These are stemiess plants related to Agaves, with glaucrus leaves of soft texture and tall spikes of red and green flowers.

*Billbergia decora, Peru.................

Leaves 2 feet long with white trangverse bands un. derneath, flowers greenish, accompanied by showy pınk bracts; a good house plant.

*Colocasia antiquorum, India..............

The well known "taro" or elephant's ear; very effective in large masses; needs pleaty of water.

*Colocasia gigantea?....................

Taller growing; leaves not so broad.

**Colocasia odora, Brazil.................

Will build in time a regular trunk several feet hĭgh.

**COLOCASIA VIOLACEA?..............

Leaf stalks and leaves deep violet color.

*Cordyline australis, New Zealand.

25 to 500

50

50

50

50

25

Not quite as tall as C. indivisa; when young Teaves broader and arching more gracefullv.

*CORDYLINE COOKII, New Zealand........

New, said to be very distinct and very pretty.

Cordyline indivisa, New Zealand. ............

Commonly known as Palmlily and Dracaena indivisa; one of the most popular house plants; rapidiy bui!ding a tall trunk branching with age.

*Cyperus alternifolius, Madagascar...........

In this country called "umbrella plant," a great fav: orite for jardinieres, aquariums, etc. 
Cyperus lucidus....................

Much taller growing and hardier; same habit of the preceding.

Dasylirion glaucum, Mexico

25 to 250

Low growing, spiny; glaucous linear leaves.

Dasylirion gracile, Mexico.

25 to 250

Arborescent, leaves spiny, bright green, ending in a spreading brush of filaments like the preceding.

Dasylirion quadrangulare, Mexico...........

Stems short, leaves 6 feet and more long, quadrangular, like those of a rush.

Dasylirion Wheeleri, Arizona...............

Dwarf, leaves glaucous, spirally twisted. All Dasy-

lirions are highly ornamental plants, fast growers will stand any amount of drought and heat, as we!l as several degrees of frost.

*Doryanthes Palmeri, Queensland...........

One of the Australian "torch lilies;" leaves broad, bright green, over 6 feet high; large scarlet flowers in spikes 8-10 feet bigh.

*Dracaena draco, Teneriffe...............

The well known "dragon tree" celebrated for one that was growing at Orotava, said to be uver 6000 years old.

*Dracaena Hookeri, Natal.................

Lately introduced, leaves broad; light green; will make a first-rate house plant.

**Dracaena terminalis, South Sea Islands ......

The leading varieties, differently striped with pink, crimson, yellow and white; chiefly recommendable for hou se plants.

*DYCKIA ALTISSIMA, Brazil............

Belonging to the bromeliacae or pineapple family, building a dense rosette of glossy, bright green leaves gracefully recurved, with brown spines; flowers bright yellow.

EUPHORBIA BIGLANDULOSA, South e r $\mathrm{n}$

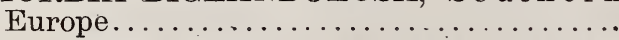

Stems covered with bluish linear leaves spirally ar ranged; very pretiy.

*EUPHORBIA CANARIENSIS, Teneriffe.... .

A tall growing, cactus like plant, with branching leafless stems.

*EUPHORBIA CLANDESTINA, South Africa EUPHORBIA DENDROIDES, Southern Europe Very showy whitish inflorescences in early spring.

*EUPHORBIA GRANDIDENS, South Africa. .

Tall growing and branching too; stems toothed all along and spiny. 
*EUPHORBIA REGIS JUB $\nexists$, Teneriffe..... .

This has cylindrical stems and narrow light green leaves.

*:EUPHORBIA RHIPSALOIDES, Zanzibar...

*EUPHORBIA TIRUCAILI, India..........

25 to 50

Growing quite a tree with cylindrical, leafless, much. branched stems; called "milk hodge" in Coromandel.

Fatsia japonica, Japan. . . . . . . . . . . . . .

Commonly known as Aralia Sieboldi, a beautiful plant with palmated, shining, dark greeu leaves and umbels of white flowers.

Fatsia papyrifera, Formosa ................

The most popular "rice paper plant"growing so freely on our coast and attaining the proportions of a tree.

*FOURCROYA ALTISSIMA, Southern Mexico

Leaves up to 9 feet high standing upright; panicle of flowers over 30 feet high; a magnificent plant.

*Fourcroya Bedinghausii, Mexico............

25 to 100

25 to 100

50 to 200

25 to 500

Known also as Roezlia regia, Yucca Parmentieri and other names; oue of the most striking and majestic decorative plants; a very rapid grower; builds a stout trunk 15 feet high and over, crowned with long, gracefully drooping bluish leaves; the terminal flower panicle will attain 20 feet or more; flowers white, woolly.

*FOURCROY.A ELEGANS, Mexico..........

Comparatively small in all its parts and blooming young; panicle of white flowers 12 feet high; very graceful.

*Fourcroya gigantea, Mexico...............

This has hardly any trunk; erect, dork green sparingly toothed leaves over 6 feet long, aud a very tall branching panicle of white flowers.

*FOURCROYA GIGANTEA VARIEGATA, probably of Garden origin............

The Queen of this genus, the broad long leaves almost entireiy ivory white under glass, changing to light yellow outdoors. Very rare.

*Fourcroya Lindeni, Central America......... Very ornamental, leaves bordered with golden yellow

*FOUPCROY A PUBESCENS, Mexico........

*FOURCROYA TUBEROSA, Mexico.........

All Fourcroyas are first rate decorative plants and are also recommendable for the fiber they yield.

GYMNOTHRIX LATIFOLIA, Uruguay...... .

Broad leaved, tall growing grass, available also for fodder. 
Gynerium argenteum, River Plate.........\$

'T he well known "pampas grass." the plumes of which are exported in cossiderable quantity from California.

*HESPERALOE DAVYI, origin uncertain....

Growing ${ }^{3}$ much larger than the following; flowers 'greenish white.

*HESPEPALOE YUCCAEFOLIA, New Mexico

A very peculiar genus; habit of Yucca; flowers of Aloe, hrick colored in this species.

*MUSA LIVINGSTONIANA, Central South

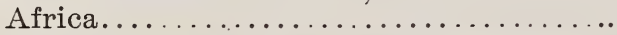

Similar in habit to M. ensete: newly introduced.

* Musa ensete, Abyssinia.................

The Abyssinian bauana, unrivalled for tropical effect; will stand slight frost, and can also be lifted from the ground and housed, where winter would be too cold ior it.

*Musa Martini, Central Africa .............

Growing more slender than the preceding, leaves shorter and less liable to be broken by wind.

NOLINA BELDINGI, Lower California........

Lately discovered by Mr. T. S. Brandegee on mountains above Cane St. Lucas; arborescent, similar in habit to N. longifolia, but with glaucous leaves.

NOLINA BIGELOWII, Arizona.............

Arborescent, tip of leaves curiously twisted and very hygrometrical.

Nolina longifolia, Mexico.................

Known also as Dasylirion longifolium, 8 to 10 feet high and more, leaves several feet long, drooping, bright green; quite an invaluable plant for decora. tion of terraces, large vases, etc.

*Pandanus furcatus, Himalaya...........2 00 to 500

Likely to prove the hardiest of all screw pines, growing at 4000 feet elevation.

*PANDANUS MACROCARPUS, New Cale-

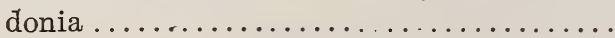

New; quite distinct.

**Pandanus Veitchi, Polynesia...........

Leaves beautifully striped white.

250

50 to 200

25 to 200

**Pandanus utilis, Madagascar..............

One of the most popular plants for house and table decoration: if planted out will need a warm nook, but partial shade.

*Panicum excurrens, Central Africa 
Panicum spectabile giganteum, Central Africa $\$$...

Both tropical looking grasses, avảilable also for cat. tle fodder.

*Papyrus antiquorum, Syria and Egypt ...... The peculiar looking "paper plant" so frequeut in Califoruia garders.

*PARATROPIA STELTZERIANA, Guatemala Growing rapidly and bushy; shining palmate leaves; a very good house plant.

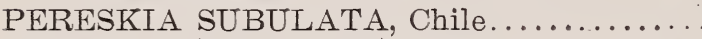
A tall growing, cactus like plant, much branched, bearing large purple flowers.

Phormium tenax, New Zealand............. Phormium tenax fol. var .................

The well known New Zealand flax and its white striped variety make beautiful and effective decorative piants, being ornamental also for their rusty flow ers.

*PITCAIRNIA COERULEA, Chile..........

Belonging to the bromeliads or pineapple family, this has a very short trunk and a large rosette of light green leaves silvery underneath: its flowers are $8 \mathrm{ky}$ blue, borne in a huge panicle 8 feet high; a striking plant altogether.

*PUYA CHILENSIS, Chile................

Another bromeliad building a vers stout trunk sev: eral feet high and brauching with age; leaves armed with hooked thorns and whitish; flowers in long panicles yellowish color.

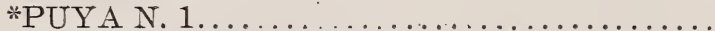

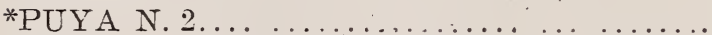

*PUYA N. $3 \ldots \ldots \ldots \ldots \ldots \ldots$

All from Chile, and growing in the same region as the preceding, but of smaller size.

**Ravenala madagascariensis, Madagascar . . . . . The far-famed "traveller's tree," will need the warmest location if planted out.

*Richardia albo-maculata, South Africa ...... The so-called "spotted Calla." making a very hardy and pretty house plant.

*SACCHARUM CILIARE, India............ Most ornamental; making large clumps; leaves sev eral feet long; a distinct whice stripe in their centər.

*Strelitzia augusta, South Africa ............ Similar in habit to Ravenala but much hardier and with glancous leaves. 
Xucca angustifolia, Colorado .............\$

Short stem, long uarrow leaves covered with white threads; flowers in a tall spike, lemon yellow.

YUCCA ARBORESCENS, California ........

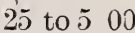

The strange looking Yueca of the Mojave and Colorado deseris, building with time regular branching tiees.

Yucea baccata, Southern California ......... Snrubby, bearing pulpy edible fruit.s.

YUCCA ELATA, New Mexico.... ... ......

Building a tall trunk; leaves narrow, similar to those. of Y. angustifolia.

Yucca filamentosa, Eastern States ............ Herbaceous, leaves bruad with a tew white filaments.

YUCCA FILIFERA, Northern Mexico..... ... Attaining 40 feet or more. trunk stout, leavies stiff, short, with filaments, drooping panicles of while flowers.

*YUCCA GIGANTEA, Guatemala? . . . . . . . .

25 to 200

The Queen of the Yuccas, growing very tall; leaves emerald green, glossy, over 4 inches wide aud several feet long, gracefuily drouping,

*Yucca guatemalensis, Guatemala............ Arborescent, 20 feet or more, leaves erect shining green.

Yucca Whipplei, Southern California.........

Stemiess, leaves glaucous, narrow, stiff, sharp pointed immeuse panicles of while flowers at times twenty feet high. All Yuceas-spanish bayonets, as they are sometimes called-will thrive in the poorest soil, aud for their habit and blossoming are adapted alike to formal as to picturesque gardening.

*XAN'THORRHCEA PREISSII, Western Aus-

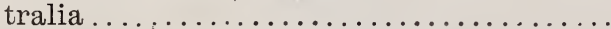

The "black boys," so called from the appearance of their stout trunks, blackish with resin and through fires, crowned with long rush-like leaves and slender spikes of greenish flowers,

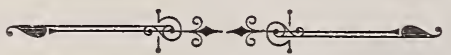




\section{FRUIT BEARING 2nd ECONOMIC PLANTS.}

Considering the remarkable results obtained already, both in Florida and in California, with the culture of Citrus and other fruits, and in Louisiana and Alabama with the culture of sugar cane, it is safe to say that every effort in this same direction, namely of introducing new and useful plants, ought to meet hearty support from every enlightened citizen, because of the evident advantage to the country. Moreover, a new and immense field is opening now, there being a host of useful Plants belonging to the tropical zone that it will be found desirable to introduce to Cuba, Porto Rico, Hawaii and the Philippines. We have made a specialty of such introductions, and we are glad to offer for the first time many plants, which from our initial experiments appear quite promising. It will be, however, only through the rational and persevering experimenting of many persons in different localities that any new fruit bearing or economic plant may be definitely acquired to the country.

Aberia caffra, South Africa............ $\quad 25$ to 50

There called the "kai apple," a thorny shrub, fruit size of a sinzll apple, will stand some frost.

*Acacia arabica, Arabia................

A small thorny tree yielding the true "gum arabic."

*Acacia catechu, India ...................

A medium sized tree, yielding the "cutch" or "catechu" of commerce.

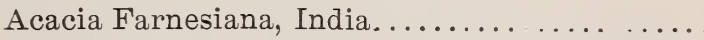

The so called "cassie" in Southern Fratice, where it is growu extensively for perfumery purposes; beginving to attract some attention in California. Price for large quautities on application. 
*Achras sapota, West Indies............... \$

The "sapodilla" or "naseberry," a small tree with dark shining leaves, fruit brown, very juicy and sweet. Yields also "chicle" or chewing gum.

*AGLAiA odorata, Cochinchina ........

A tree bearing yellowish flowers deliciously scented, employed to perfume some peculiar brand of tea.

**ALANGIUM HEXAPETALUM, India ....

Roots and bark possessing medicinal properties, fruits edible.

*ALEURITES CORDATA, Southern China...

A tree yielding the best lac varnish.

*Aleurites moluccana, Moluccas ............

The "candle nut" tree, from the nuts the "kekune oil" is obtained; fresh nuts have quite a pleasant taste: a rapid grower and beautiful shade tree, with foliage like maples; new leaves of pinkish color.

*Amomum cardamomum, Ceylon ..........

The cardamom, having aromatic leaves and seeds.

**Anacardium occidentale, West Indies .......

Producing the peculiar looking "cashew nuts"; also gum -imilar to gum arabic.

*Ananas sativa, tropical America ... . . . ....

The pine-apple, of which we can furnish the following leading varieties: black Jamaica. Porto Rico, red Spanish, Ripley queen, smooth Cayenne, sugar loaf. Full details and prices for large quantities will be furnished on application.

* Anona cherimolia, Peru.................

The "cirimoya," by some people wrongly called "custard apple," this being the West Iudian name for A. retisulata. A smail, bushy tree with broad, aromatic leaves and allspice fragrant flowers, bearing quite young variously shaped fruits, attaining 2 and more pounds in weight. the consistence of ice cream when perfectly ripe. Planted to a certain extent in Montecito and in the Cahuenga ralley. Fruits find ready market at high prices. both in santa Barbara and in Los Angeles, and if picked green wiil easily bear distant transportation.

*ANONA MACROCARPA, South America ...

Said to bear larger fruits, as hardy as the preceding.

**Anona muricata, West Indies..... . ......

The "sour sop," a small tree. with beautiful glossy leaves; fruit large, covered with soft prickles, very juicy and refreshing.

* ANONA RENIFORMIS, South America .....

25 to 200

Leaves small, dark green, promises to be even hardier than A. cherimolia. 
**Anona squamosa, tropical America ........\$

The "sugar anple,"grown to some excent in southern Florida; leaves, green iruits and seeds much used to destroy vermiu, and good for digestion.

*ANONA SUAVISSIMA, South America? ....

Growa for many years in southern Europe; probably a hardier form of $\mathrm{A}$. cherimulia.

*ANTIDESMA BUNIUS, Malayan Archipelago

A tree dark green foilage; small, round berries of a subacid taste, much used for preserves; quite hardy here.

Apios tuberosa, Eastern States. .............

A pereunial vine with fragrant flowers and edible tubers.

Arbutus unedo, South Europe and Ireland.....

The so-called "strawberry tree," pretty, waxy, bellshaped flowers; fruit round, containing a large amount of sugar.

*ARTABOTRYS ODORATISSIMA, India ....

A vigorous climber; leaves shining, aromatic; flowers yielding the celebrated "ylaug-ylang" perfume.

**Averrhoa carambola, Ceylon.............

Elegantly cut light green fuliage; pleasant acid refreshing fruit.

BENTHAMIA FRAGIFERA, Himalaya. ..... A small tree; fruit in appearance and size like the largest strawberries.

**BERTHOLLETIA EXCELSA, Brazil ....... A loity t:ee, yielding the well know u "Brazil nuts" of faucy fruit stores.

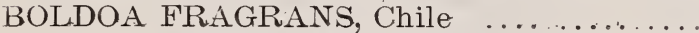

A small tree with fragraut evergreen leaves, bark used for tauniug; berries edible.

**BURSERA GUMMIFERA, West Indies... .

A tali, deciduous tree with erect, clean stem and spreadiug head, yielding a gum similar to gum mastic.

${ }^{*}$ CAJ ANUS INDICUS, India ... . . . . . . .

A pretty shrub with yellow aud maroon flowars, blooming all through the year, and bearing a continuous crop of richly nutritious peas.

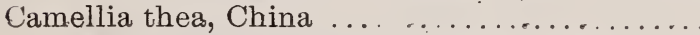

The well known "tea plant," a pretty evergreen shrub with white flowers, like small single camelias.

*CANARINA CAMPANULA, Canary Islands. A perennial vine with orange color, bell shaped Howers; berries' enible. 
CAPPARIS SPINOSA, Southern Europe . ...\$

Yields the well known "capers"; also very ornamenta] for rockeries and hanging baskets, on account of its habit and showy flowers.

*Capsicum baccatum, from Texas southwards...

In Texas called "bird pepper' from wild turkeys being exceedingly fond of it. Supplies the bulk of the "Carenne pepper" of commerce.

**CAPSICUM FRUTESCENS, SouthernMexico

The tree pepper, from which fruits the celebrated "Tabasco sauce" is manufartired.

*CARICA CUNDINAMARCENSIS, Colombia. Probably the most hardy of all "melon papaws"; makes rapidiy a bold foliage plant: the sweet scented yellowish flowers being produced here all the year.

**CARICA GRACILIS, South America........

Palmated finely cut leaves all veined with pink : fruits small.

**Carica Papaya, tropical America ... . . . . . . .

Common Melon Papaw or "melon zapote" of the Mexicans.

*CARICA QUERCIFOLIA, Paraguay and River

Plate...

A quick growing, hardy kind, with small friiits: but its large hallebard shaped leaves containing a higher percentage of "papaine" now much used in medicine in preference to "pepsine."

*Carissa grandiflora, South Africa . . . . . . . . .

Called also the Natal plum; a spiny shrub, leaves dark green, flowers large, white, fragrant; fr'ilits red, size of a cherry, very nice eating.

*CASIMIROA EDULIS, Mexico

25

The "zapote blanco," much prized for its fruit in it. native country; a large specimen over 80 years old is to be seen in Santa Barbara.

*Castanospermum australe, Queensland ... ...

The "Moreton bay chestnut," not less conspicuous for its rich foliage and handsome saffron colored flowers than for its globular seeds, larger than any Italian chestnut, to be eaten roasted like these.

*CEIBA OCCIDENTALIS, N orthwe stern Mexico

The "ceibn" and "pochote" of the natives; a large sprearing tree with beautiful flowers and large fruits filled with silky fibers usea to stuff pilìows, etc.

*Ceratonia siliqua longissima, Mediterranean

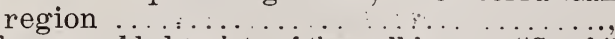
A longer podded variety of the well known "Caroh", or "St. John's bread." 
*CHORISIA SPECIOSA, Brazil ..........\$

A medium-sized spiny tree, yielding the "floss silk" used for mattresses.

*Cinnamomum camphora, Formosa...........

The well known Camphor tree, growing to perfection all over California.

*Cinnamomum zeylanicum, Ceylon .......

A tree yielning the true Cinurmon of commerce.

*Citrus aurantium and Citrus medica, Northern India ............

Orange and lemon,-We can supply all the leading varieties of Oranges, Lemons, Limes. Citrons, Pomelos, and all kinds of Citrus fruit, and will submit detailed lists and price for large quantities on application.

* Coffea arabica, Harrar ................

Common coffee; exceedingly ornamental, too, for its shiuing leaves, white, fragrant flowers and red berries.

*COOKIA PUNCTATA, Southern China .....

The "Whampi"; much prized for its richly arımatic fruits, shape of small oranges.

**Crescentia cujete, West Indies

"Calabash tree"; hard shell of fruits being used in place of pottery-ware.

${ }^{*}$ CROTON TIGLIUM, Southern China........

A small tree yielding the well known "croton oil"; also a striking plant for the neculiar hues of its leaves, varying from metallic green to bronze and bright orange.

*CUPANIA ANACARDIOIDES, East Australia Beautiful evergreen tree; rapid grower, fruit edible.

Cyphomandra betacea, South America.......

The "tree tomato." berries large, egg shaped: bright orange at maturity.

*CRATAEGUS MEXICANA, Mexico ........

A tall shrub with red fruits, sold everywhere in Mexico under the name of "Tecojote."

*DIOSPYROS EBENASTER, Mexico........

The "Zapote negro," a tall shady tree; fruits size of an orange, green outside, almost black inside, very sweet.

Diospyros kaki, Japan................... Japanese persimmon, of which we can furnish several choice varieties.

Diospyros virginiana, Southern Eastern States. . The native Persimmon, generally smaller than the preceding. Of this also we can offer several choice varieties. 
Eriobotrya japonica, China and Japan

25 to 100

The "loquat" well known to everybody.

*Eugenia jambolana, India . . ...........

The "jambolan plum," a handsome tree, fruits much prized in its native country.

*Eugenia jambos, India................

The "rose apple," fruits large, rose scented.

Eugenia myrtifolia, East Australia..........

25 to

Mostly grown as qi ornamentrl tree; its violet berries are, howerer, liked hy many.

*EUGENIA PITANGA, Brazil.............

Generally confused with E. Brasiliensis and uniflora; this has medium size shiny leaves; fruits scarlet shaped like a small tomato, very pleasant to eat and making excellent jelly.

Eugenia ugni, Chile

A pretty shrub; purple edible berries.

Excœearia sebifera, China. ..............

The tallow tree, a sort of wax or tallow being extracted from the berries.

Ficus carica, Southern Europe ..............

The common fig, of which wo are readv to supply the leading varieties; detailed lists on application.

*Ficus elastica, India ..................

The well known "rubber tree," supplying one of the best rubbers of commerce; grown also extensively as decorative house plant.

*Ficus glomerata, India.................

The cluster fig, or countrv fig, making a fine shade tree, and bearing a profusion of small fruits much relished by catrle and chiidren.

*FICUS PALMERI, Western Mexico.........

Recently discovered by Dr. Palmer near Manzanillo, and afterwards found also on the southern end of the peninsula of California; a medium sized tree bearing small, round, white figs, very sweet and pleasant.

*FLACOURTIA RAMONTCHI, India........

The "rambustan" or governor's plum, a dense leaved, spiny shrub. admirable for hedges; fruits purple, size of a plum.

**Garcinia morella, India... . . ...........

Yielding the yellow color known as "Ceylon Cam. bodge." Closely related to G. mangostana, considered the best of all tropical fruits.

*Garuga pinnata, India.................

A large tree; fruit size of a gooseberry, used in pickles and medicinal. 
*Guaiacum officinale, from Texas southwards ...\$

A small tree with bright, light blue flowers; yielding the far famed "lignum vitæ," employed in medicine as well as for other industrial purposes.

*GUAZUMA ULMIfOLIA, Mexico ...

There known as "Guacima." a large tree; wond. hark and fruits of economic value.

*Hibiscus elatus, Cuba. ...... . . . . ......

"Mountain mahoe,"a larg э tree yielding "Cuba bast," used also to bind cigar bundles; leaves and young shoots medicinal, wnod very valuable.

**HYMEN AA COURBARIL, West Indies ...

A lofty tree, from which "gum animi" is obtained.

**Inga dulcis, Central America.............

A bushy tree; pods containing white pulp rich in sugar.

**INGA FEUILLEI, Peru...............

The "Pacay"; the sweet pulp of the pods much prized by the natives.

*Jatropha curcas, tropical South America ...

Known also คs Curcas purgans, or "physic nut," a nowerful purgative, employed also for other uses in medicine.

Juglans regia, Europe ... ................

Common or English walnut: all leading varieties, among them the "Santa Barbara soft shell," well known in the market.

*Lawsonia alba. India

A shrub with fragrant white flowers, yielding "henna," much used in Egypt and other countries by women to color their nails and by men to dye their beards.

LITHR AA MOLLEOIDES, Chile............

A quick growing, pretty evergreen tree; fermented fruits supply much prized "ehica" or brandy.

**Lucuma Rivicoa, West Indies ..... . . . . . .

Fruits similar to the Sapodil!a; more tender.

*LUHEA spec? Paraguay ... . . . . . . . . . .

$t$ middle sized tree; inner bark there used generally in place of string; very hardy and easily propagated; a promising introduction for the Sonth.

* Macadamia ternifolia, Queensland ... . . ....

A small tree with beautiful foliage and excellent nuts known as "Queensland nuts." 
**Mangifera indica, India...............\$

The Mango, one of the must beantiful trees in existeuce, with delicious fruit, of which not less than 133 varieties are cultivated iu Iudia. Some of these are sure to succeed well in our Southern States.

**Manihot Aipi, tropical America ..........

The "sweet Cassava," now grown to some extent in Florida; likely $ڤ$ give profitable crops in Southern California.

**MANIHOT GLAZIOUI, Brazil ...........

A tree yielding the "Ceara rubber," now extensively cuitivated in India and in Ceylon up to the aititude of 4,000 feet.

**Manihot utilissima, tropical America..... . . . This yields "bitter cassava," from which true "tapi. oc:a" and "cassareep" are prepared.

**Melicocca bijuga, West Indies... . . . . . . . . .

The "genip" or "momoncillo," a large tree with very odd foliage, fruitgreen, size of a pigeon egg, of very pleasant taste; seeds eaten roasted like chestnuts.

*MELALEUCA CAJEPUTI, India ... ......

Yrelding '‘cajepur oil,' powerfully aromatic and prized in medicine.

*MIMUSOPS DISPAR, Natal............

A smaller tree than the following; fruits size of an olive.

**Mimusops elengi, India................ A very handsome evergreen tree; flowers used in perfumery; fruit eảible.

**MIMUSOPS GLOBOSA, Venezuela........ Yields the "Balatia" rubber, considered to be one of the best on the market.

*Monstera deliciosa, Mexico............... The "Cerimon"; a strikingly ornamental vine, bearing coneshaped fruits, tastiug somewhat like pineapples.

*MORINDA CITRIFOLIA var. BRACTEATA

A small evergreen tree with large glossy leaves and white, sweet-scented flowers; iis roots yield a much prized yellow dye.

*.Musa, all over the tropics..............

The banana and prantain, of which we can supply the following species and varieties:

"Cavendishii or sinensis,"

Dwarf, bearing very large bunches of excellent fruit. 
"Orenoco,"

Tall growing, and the hardiest of all; fruit large. quality medium.

"Hart's choice,"

Not very tall; slalk and midrib tinged witb red; fruit clear yellow, thin skinued, of a very superior quality.

"Red Jamaica or Baracoa,"

Growing very tall; fruit red; more tender than the preceding.

Olea europaea, Southern Europe........ . ...

The common olive; of this we can supply all the leading varieties, both for pickling and for oil making; detailed lists and prices for large quantities furnished on application.

*Opuntia ficus indica, Mexico . ............ The "prickly tree" or "Barbary fig," a selection of the best varieties cultivated in Southern Europe.

*Passiflora edulis, South America............

"Edible passion fruit," or "grenadilla," a most vigorous grower and immense bearer; fruit size of an egg, violet colored, full of a very pleasant pulp.

**PASSIFLORA LAURIFOLIA, West Indies. . The "water lemon," a climber with splendid foliage and brown colored excellent fruits twice as big as the preceding.

*Passiflora quadrangularis, tropical South

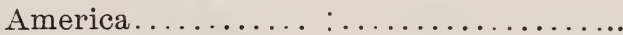

A beautiful climbe $z$ with rich foliage, very large, show 5 , strongly fragrant flowers, and fruits attaining several pounds in weight.

*Persea gratissima, Mexico. .

The "ahuacate" or "alligator pear,"called alsn "Avo. caliel" in the Freach colouies aud "midshipman's butter," in the British; a beautiful tree bearmg large violet fruits much prized in all tropical countries, and for which a steadily increasing demaud has come up also in the United States.

Phormium tenax, New Zealand.............

The "New Zealand flax" already mentioned under decorative plants, but likely to attain economic interest in some parts of the country, owing to quality of its fiber. of which there is quite a large import into the United States.

Physalis Francheti, Japan... ... .........

Probably ouly a giant form of the P. alkekengi or "bladder cherry," lately much advertised as "Chinese lantern cherry." Very hardy. 
*PILOCARPUS PENNATIFOLIUS, Brazil... .\$

A small tree, yielding the celebrated "jaborandi" possessing wonderful sudorific properties.

PINUS EDULIS, New Mexico.............

A medium sized tre€, nuts very nice, known as "pinones." uncier which name also some other species go.

Pinus pinea, Italy . . . . . . . . . . . . . .

The picturesque umbrella or stone pine, so familiar in Italian landscapes, yieldiug delicately flavored nuts much used in confectionery, etc.

**PIPER NIGRUM, India................

A somewhat sueculent vine, yielding the true black pepper of commerce.

Pistacia vera, Asia Minor................ The most delicious "pistacio nut" used in confec tionery.

*PITHECOLOBIUM MEXICANUM, Mexico. .

There called "chino," a small tree much prized for peculiar tanning material it affords; recently discovered by Dr. Palmer, has been described and named by Dr. Rose of the U. S. Dept, of Agriculture.

*POGOSTEMON PATCHOULI, India........

A soft-wooded small shrub, supplying the "puchapat" or "patchouli" well kuown in perfumery.

*PROSOPIS DULCIS, Panama.............

There called "algarrobo," producing vers long pods filled with sweet, white pulp. In the Hawaiian Islauds, where it was introduced by missionaries some 40 y:ars ago, considered a blessing for its quick growth and for the immense amount of fodder and fuel it supplies.

PRUNUS CAPULI, Mexico south to Peru.... The "capulin," a very large growing kind of cherrs, with flowers in spikes appearing in winter, blackish cherries in long bunches, bitterish but very pleasant both fresh and drier.

PRUNUS PUDDUM, Himalaya............. Coming from 8.000 feet elevation. is likely to stand some cold; and likely to prove most interesting even for hybridizing purposes, as it blossoms in November and ripens its iruit in April.

*Psidium Araca, Brazil. ................

Said to be one of the very best Guaras. 
*Psidium Cattleyanum, Brazil ............ .

The "strawberry guava" quite extensively planted in California.

*Psidium Guava, South America. . . . . . . . . .

The so called "lemon guava," mostly prized for jellies and preserves; we have on trial many varieties from different countries, and will communicate particulars on application.

*PSIDIUM GUAYAVILLAS, Brazil..........

A distinct looking species; said to have smaller fruit but of superior taste.

*Psidium lucidum, Brazil ....... .....

Knowu aiso as "yellow strawberry guava," similar to P. Cattleyanum, but fruit yellow, larger and of better taste. In Florida grown quite extensively.

Psoralea glandulosa, Chile................

"Culen" and also Jesuit's tea, from the aromatic properties of its leaves; blue and white flowers.

*PTEROXYLON UTILE. South Africa...... .

A handsome evergreen tree; wood very valuable, called "sneezewood" on account of its very pungent odor.

QUILLAYA SAPONARIA, Chile.

A midale sized evergreen tree, yielding the bulk of the "soap bark" used in this country.

*RANDIA, probably an undescribed species.... sonora aud Lower California; there called "papache" a spiny shrub or small tree with white, fragrant, garcienia-like fluwers, and violet eolored fruits size of au egg, pulp juicy aud pleasaut.

*RHIZOPHORA MANGLE, all tropical coasts. The "mangle dulce" or mangrove, the only tree that will grow submerged ili salt water; gave origin to the story of oysters growing on trees; fruits edible, size of a cherry.

*Rhodomyrtus tomentosa, India............ A pretty shrub; flowers pink; purple edible berries.

RHUS VERNICIFERA, Japan............. Allied to the Sumachs of the Eastern States, this yields one of the finest lacquers knowu. 
Rumex hymenosepalus, from California to New Mexico .......................\$

"Raiz coloradi" and "'anaigre," so much spoken of of late years as a tanning material, hardly surpassed in percentage of pure tannic acid. Leuf stalks nsed as rhubarb, for which reason it is known also as "pie plant" in California. Price for large quantities quoted on application.

*SALPICHROMA PHOMBOIDEA. Paraguay.

A climbing plant with pretty whitish bell shaped flowers, and small white berries sold everywhere in Paraguay as "huevos de gallo" or cock's eggs.

Salvia officinalis, Southern Europe. . . . . . . . . .

The true "Sage," better than any other for flavoring.

*SAPINDUS, probably a new species. Lower

California

A medium sized tree; fruits said to be edible.

*Sapindus Saponaria, West Indies. . . . . . . . . .

The "soap berry tree," now grown in most tropical countries; berries used to wash woolen goods, ete.

*SAPINDUS UTILIS, Southern China ........

This is likely to prove one of the most valuable of our introductions. It is a moderate sized deciduons tree with elegantly divided leaves, bearing quite young large crop of berries which contain over 28 per cent of "saponine." In Algeria, where this tree is heginning to attract considerable attention, trees 8 to 10 years old are known to hear from 50 to 100 francs worth of berries every year; will prefer dry rocky soil.

**Sechium edule, Mexico.................

Known as "chocho".nd "chayotte," a rigorons climber of the gourd family; fruits much prized as a very delicate vegetable marrow: large tuberous roots are edible too.

Shepherdia argentea, Northwestern States.....

The Buffalo berry, a tall shrub with silvery foliage and oval acid berries; well worth to be b rought under cultivation.

*SIMMONDSTA CALIFORNICA, Southern California, Arizona and New Mexico..... A shrub nearly related to the boxwood. "Jojoba" of the Mexicans. Myrific properties as hair restorer attrihuter to oil expresser from the seeds. 
**SIDEROXYLON MASTICHODENDRON,\$

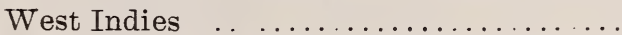

A large tree yielding a sort of chewing gum and very hard wood.

*SOLANUM GUATEMALENSE, Guatemala..

Known as "Pepino" and "Melon shrub"; soft wooded: violet colored flowers; iruits size of a goose egg, pointed,lemon yeliow; striped purple: when perfectly ripe partaking of the pineapple and the musk melon.

***SWIETENIA MAHOGANY, Gulf of Mexico. .

A lofty tree attaining immense size: yielding one of the most valuable furniture woods.

**Tamarindus indica, India ...............

The "Tamarind," a magnificent shade tree; pods full of pleasant subacid pulp.

**TELFAIRIA PEDATA, Zanzibar.... . . . .

A noble vine attaining large size; leaves palmate, shining dark green; flowers purple and white with fringed petals; fruit in shape of a gourd, 2 to 3 feet long, containing up to 250 large flat seeds edible and very rich in oil.

**Vanilla planifolia, tropical America........

The true vanilla of commerce; a climber belonging to the orchid family; will succeed only where high temperature and permanent moisture are combined together.

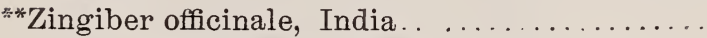

Root yielding the true "ginger" of commerce.

N. B. Apple, Pear, Peach, Plum and other so-called deciduous fruit trees we are ready to supply at proper season. Speciallists and prices for quantities on application.

\section{TIMBER, Shade AND ORNAMENTAL TREES.}

The day is approaching fast when our country will awake to the necessity of stopping the reckless destruction of its timber resources and of paying earnest attention to the 
problem of reforestation; and it would be desirable that by that time some positive experience had been gathered concerning trees adapted to different localities and yielding timber that will command higher prices. Among the following many will be found well worth experimenting in our Southern States. An increasing demand for choice shade and ornamental trees suitable to park and street planting has started already; of these a large selection is offered below. Figures affixed denote ultimate height attained by each kind under favorable conditions.

Abies cephalonica, Ionian Islands, $70 \mathrm{f} \ldots \ldots \ldots \$ 50$ to 200 Abies cilicica, Asia Minor, $60 \mathrm{f} \ldots \ldots \ldots \ldots$...... 50 to 200 Abies concolor, California, $250 \mathrm{f} \ldots \ldots \ldots \ldots . \ldots 50$ to $2 \dot{0} 0$ Abies nobilis, Oregon, $250 \mathrm{f} \ldots \ldots \ldots \ldots \ldots . \ldots 50$ to 200 Abies Nordmanniana, Crimea, $160 \mathrm{f} \ldots \ldots \ldots \ldots$...... 25 to 200 Abies pectinata, Southern Europe, $200 \mathrm{f} \ldots \ldots .50$ to 200 Abies Pinsapo, Spain, $80 \mathrm{f} . \ldots \ldots \ldots \ldots \ldots . \ldots 50$ to 200

All Abies or "Firs" are the noblest ornament of the tallest mountains, and not less suitable for parks and gardens, Ought to be planted more frequently in Caiifornia. most of them doing remarkably well here.

*ACACIA CAVENIA, Chile, $30 \mathrm{f} \ldots \ldots \ldots \ldots$.

*Acacia dealbata, Australia, 100 f............

*Acacia decurrens, Australia, 100 f...........

*ACACIA ELATA, Australia, 70 f. ..........

*ACACIA FLEXICAULIS, Southern Texas and

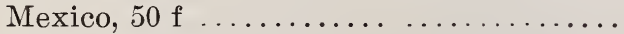

*Acacia longifolia, Australia, $30 \mathrm{f}$.........

*Acacia melanoxylon, Australia, $100 \mathrm{f}$..... ...

*Acacia mollissima, Australia, 100 f. .........

*ACACIA PENNINERVIS, Australia, 40 f....

*ACACIA PRAVISSIMA, Australia, $40 \mathrm{f}$

*Acacia pycnantha. Australia. 90 f........... 
*Acacia retinodes, Australia, 30 f........... \&

Of the above the Chilian and Mexican species are spiny, the first with orange yellow, the second with liglit yellow fragrant flowers; the Australian sp əcies have no spines and generally very elegant foliage and beautiful, sweet-scented flowers of various shades of yellow: A. dealbata being the one grown so extensively for cut flowers in Southern Europe; A. melauoxylon making a pyramidal dark green tree suitable for avenues; $A$. retinodes being literally everblooming; A. pycuantha. besides being one of the most showy flowered, is particularly rich in tannin. Many other recommendable Acacias of smaller size will be found under oruamental shrubs. Acacias as a rule will thrive in poor and dry soil without irrigation.

*ACROCARPUS FRAXINIFOLIUS, India,100 f.

$A$ handsome tree affording good shade, and valuable timber.

*Agathis robusta, Queensland, $130 \mathrm{f} \ldots \ldots \ldots$....

The correct name for Dammara robusta; a magnificent conifer with broad, laurel-like leaves, yielding with its congeners the much prized dammar resin.

*ALBIZZIA FASTigiatA, South Africa, $30 \mathrm{f}$. Albizzia julibrissin, Asia Minor, $25 \mathrm{f} \ldots \ldots \ldots \ldots$ Deciduous: large pink colored flowers in summer; will stand many degrees of frost.

Albizzia lophanta, Australia, $2 \tilde{f}$............. Naturalized in California; produces an immense amount of seeds; nothing better for covering quick waste places, etc.

**ALBIZZIA MOLUCCANA, Moluccas, $50 \mathrm{f} .$.

*ALBIZZIA OCCIDENTALIS, Lower California

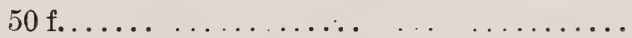

There-called "palo escopeta." of elegant shape with cream colortd fragrant flowers and very long pods

**ALBIZZIA ODORATISSIMA, India, $80 \mathrm{f}$.. Flowers greenish white in panicles, apricot scenter; timber valuable.

*ALBIZZIA PROCERA, India, $100 \mathrm{f}$. . . ...

*Albizzia stipulata, India, $100 \mathrm{f}$........... . . A beautiful tree with large stipules on the young shoots; very rapid grower. 
*Aleurites moluccana, Moluccas, 50 f........\$

Wentioned already under economic plants, makes also a beautiful shade tree with peculiar looking foliage.

*Araucaria Bidwillii, Queensland. $150 \mathrm{f} \ldots \ldots 100$ to 500 The "bunya-bunya," a truly magnificent tree, of which quite remarkable specimens are to be seen in Los Angeles.

*Araucaria excelsa, Norfolk Island, $150 \mathrm{f} \ldots \ldots 100$ to 500 A striking spire looking tree so noticeable in Santa Barbara, where it has been planted quite extensively.

Araucaria imbricata, Chile, $100 \mathrm{f} \ldots \ldots \ldots \ldots 100$ to 500 Going here under the puzzing name of 'monkey's puzzle" (there being no monkeys where it naturally grows); a curious and remarkable tree, not such a fast grower as the above, but generally doing well on the Pacific coast, and will stand several degrees of frost. Arbutus Menziesii, California and Oregon, $100 \mathrm{f}$. A magnificent evergreen tree, the king of its genus, known in Cali fornia as "Madrono," the Spanish name also for other species of Arbutus.

*Baphia racemosa, Natal, 20 f............. Much branched and desse growing: flowers white smelling like violets.

*BARKLYA SYRINGAEFOLIA, Australia. 50 f. A handsome evergreen; flowers bright yellow.

*BURSERA SERRATA, India, 30 f......... $A$ beatiful evergreen tree, wood used for furniture. BUTEA FRONDOSA, India, $50 \mathrm{f}$.......... A shady tree, yielding a kind of gum-kino; flowers orauge crimsou, very showy.

${ }^{*}$ CALLITRIS ROBUSTA, Australia, 100 f.... similar in habit to some Cypress; wood prized for cabinet work.

*Calodendron capense, South Africa, 70 f...... Well named the "beautifu) (ree" on account of its symmetrical shape, foliage resembling that of the chestuut, and flesh colored flowers in terminal panicles; ought to make a fine avenue tree.

*CARUMBIUM POPULIFOLIUM, Australia.

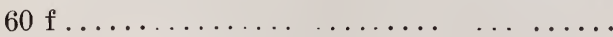
Fast growing; foliage of coppery color. 
*CASUARINA CUNNINGHAMIANA, Queens-\$

land, $70 \mathrm{f} . \ldots \ldots \ldots \ldots \ldots \ldots \ldots \ldots$

25 to 50

The correct name for C. tenuissima, a garden name.

*Casuarina equisetifolia, South Asia and North

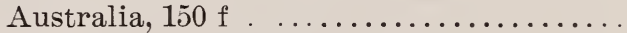

*Casuarina glauca, Australia, 50 f...........

*Casuarina stricta, Australia, 50 f...........

All Casuariua or "she oak." as they are called, are $\mathrm{p}$-culiar looking trees with greyish, generally pendu lous brauchiets looking like gigantic horse-tails, and they are invaluable indeed for the rapidity of their growth, ald consequent supply of fuel, and for their adaptability to thrive in brackish and alkaline soils, as well as on the pure sand of the seacoast.

Catalpa speciosa, Mississippi Valley, 100 f...... A very handsome shade and flowering tree; wood very valuable.

${ }^{*}$ CEDRELA DUGESII, Mexico, $30 \mathrm{f} . . . \ldots . . .$. *CEDRELA FISSILIS, Brazil and Paraguay,

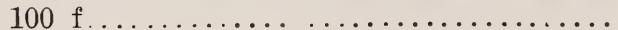

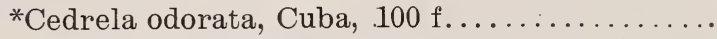

*CEDRELA SERRATA, Himalaya, 100 f....

Cedrela sinensis, Northern China, $70 \mathrm{f} \quad$. . . .

All of them kuown as "cedar wood" ou account of the aromatic fragrallce of their excellent wood. C. . dor. ata suppliss the boxes of the genuiue Havana cigars. C. serrata grows up to 8,000 feet altitude and is likely to prove hardier than the others, with the exception of C. sineusis hardy at New York.

Cedrus atlantica, Northern Africa, $200 \mathrm{f}$... . .

Pyramidal growing: silvery foliage; will stand drought better than the two following.

Cedrus deodara, Himalaya, $300 \mathrm{f}$. .

To be sure one of the most handsome and majestic coniferous trees, doing very well in Califurnia, as shown by the fine specimens in Los Angeles.

Cedrus Libani, Asia Minor, $200 \mathrm{f}$....

The Cedar of Lebanon of biblical recollection; a majestic tree when fully developed, but of slow growth. *CELTIS KRAUSSIANA, Natal, 60 f........ 
*CELTIS SINENSIS, China and Northern India.\$

$50 \mathrm{f} . \ldots \ldots \ldots \ldots \ldots \ldots \ldots \ldots \ldots \ldots \ldots$

A beautiful shade tree, with dark green foliage and dull red berries; wood elastic and durable like of other "nettle or hackherry trees."

Chamaecyparis Lawsoni, North California, $100 \mathrm{f}$. The Lawson cypress: a most elegant and hardy tree. of which so many varieties are grown at present.

*Cinnamomum Camphora, Formosa, $100 \mathrm{f}$... Already mentioned under economic plants; one of the best aventie trees for the south.

*CINNAMOMUM GLANDULIFERUM, Formosa, $100 \mathrm{f} \ldots \ldots \ldots \ldots \ldots \ldots \ldots \ldots \ldots$ Similar to the above with broader leares and quicker growth.

*CINNAMOMUM PEDUNCULATUM, Japan.

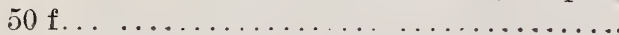

*Corynocarpus laevigata, New Zealand, $40 \mathrm{f}$... Compact growıng with glossy leares.

Cryptomeria japonica. Japan, 1:20 f

The Japan cedar, rielding a much nrized timber and making a beauliful areune tree; does well here right on the coast

Cunninghamia sinensis, China, $100 \mathrm{f}$ Resembling in habit Araucaria Bidwillii, but of lighter colur, many fiue thriving specimens to be seen aruand Pasadelia.

*CUPRESSUS BENTHAMI, Mexico, $100 \mathrm{f} . .$. Growing very fast, foliage of bluish color.

Cupressus funebris, Himalaya, $50 \mathrm{f} . . .$. .

The weepiug cypress, a striking and ornamental tree, most s'lited for cemeteries.

Cupressus Guadalupensis, Guadalupe Island, 50 f. An elegant, oruamental, and fast growing species of bluish color, specially recommendable for windbrakes, as it will grow faster and more compact and stand drought better than C. macrocarpa.

CUPRESSUS LUSITANICA. China? $100 \mathrm{f}$

25 to 100

25 to 100

25 to 50

100

25 to 100

250

50

25 to 100

Another "blue cypress" known also as C. glauca and Goq cypress, quick growing and very ornamental. 
Cupressus macrocarpa, California, $150 \mathrm{f} \ldots \ldots . \$$

25 to 100

The well known 'Monterey cypress," invaluable indeed for hedges, screens and windbrakes, and with age makiug stately majestic trees, rivalling in appearance the celebrated Cedar of Lebauon; will thrive in any position and any kind of soil.

Cupressus sempervirens, Asia Minor, 100 f..... Here called "Italian cypress," and frequently planted in gardens, cemeteries, etc.; wood very fragrant and durable.

Cupressus torulosa, Himalaya, $100 \mathrm{f}$. . . . . . . . .

A beautiful tree of conjcal shape, quite spreading at the base; fast grower; wood very valuable.

*Dalbergia latifolia, India, $80 \mathrm{f} \ldots \ldots \ldots \ldots \ldots$. .

Rosewood or blackwood, one of the most prized furniture woods of India.

*DALBERGIA SISSOO, India, 60 f......... One of the most prized timbers in India for its elastic. ity and durability, makes also a beautiful ornamental tree and has the great advantage of thriving even in rocky and äry soil and of standing well flooding, as has been proved by some plantations in Egypt. Known to succeed in sections of India having only 15 iuches rainfall, intense heat in summer and sharp frosts in wincer.

*DOMBEYA NATALENSIS, Natal, 30 f...... A small, dome shaped tree. covered with sweet scented white flowers, reminding of eherry blossom: from November through great part of the winter.

*DOMBEY A sp. N. 1., Central Africa, 50 f.... Having broader foliage aud larger flowers of bright pink coior; sairi to be a strikingly beantiful thing when iu bloom.

״DOMBEYA sp. N. 2, Central Africa......... Of about same size alid habit: flowers pure white.

EHRETIA ELLIPTICA, South Texas and

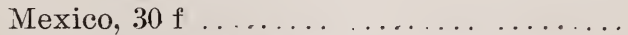

There called "auagua," a pretty evergreen tree with white flowers.

EHRETIA MACROPHYLLA, Japan, 30 f .... Similar to the above, but witn much broader leaves.

*EL EODENDRON AUSTRALE, Queensland. . Quite remarkable for its pretty holly-like leaves. 
ENTELEA ARBOPESCENS, New Zealand, 30 f.\$

A very fast grower, with large roundish leaves.

*ENTEROLOBIUM CYCLOCARPUM, from

Cuba southwards, $150 \mathrm{f}$. . .

"Orellera" of Cuba, from pods curiously shaped like human ears, and "Timboo." of the Braziliaus; a lofty tree with deciduous foliage and white flowers; a very rapid grower.

*ERYTHRINA BOGOTENSIS, Columbia, こ0 f.

*Erythrina Caffira, Natal, 70 f..............

*Erythrina corallodendron, Mexico, 50 f. ......

*ERYTHRINA INSIGNIS, South America, $100 \mathrm{f}$

*ERYTHRINA VIARUM, South America, $100 \mathrm{f}$.

Native name "ceibo"; almost spineless and evergreen; flowers orange color in large terminal cnrymbs, very showy. All Erythrinas or "coral trees" as they are commonly called, have generally spiny trunk and branches, and are covered with vermillion or scarlet flowers, exceedingly showy; very rapid growers; some of the largest kinds are $u$-ed to protect from the sun plantations of coffee and of cacao; hence their name in South Ameri.a of "mrdre del ca"an."

*Eucalyptus botryoides, Australia, $100 \mathrm{f} \quad$.....

A handsome regular shaped tree; nne of the best for aveuues.

*Eucalyptus calophylla, Southwest Australia, $70 \mathrm{f}$.

Foliage large aud rich, gives more shade than any other.

*Eucalyptus citriodor"d, Australia, $100 \mathrm{f}$. . . . . .

The "lemon scented gum" so much prized in California; trunk slender, smooth, white; foliage exhaling exquisite perfume.

*Eucalyptus cornuta, Australia, $60 \mathrm{f}$

Suitable jor plauting in alkaline and saline soils.

*Eucalyptus corynocalix, Australia, 100 f. . . . . .

The "sugar gum"; leaves and twigs eagerly browsed by cattle.

*Eucalyptus ficifolia, Australia, 30 f. . . . . . . .

No doubt une oi the most hand some trees of moderate size to be grown in temperate regions for its compact. growth, rich foliage, and chiefly for the profusion of its dazzling flowers, ranging from scarlet to crimson. 
Eucalyptus globulus, Australia and Tasmania, $\$$

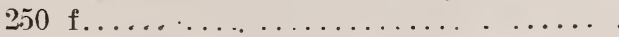

The popular "blue gum"; by far more extensively plauted than any other tree in California.

*EUCALYPTUS MARGINATA, Southwest

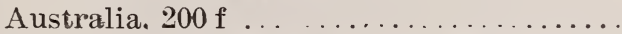

Yields the famous "Jarrah" wood, considered to be almost indestructible. Not such a fast grower as others of less value.

EUCALYPTUS RAMELIANA, Garden hybrid. Originated in Algeria; said to stand drought better than many others.

EUCALYPTUS RISDONI, Tasmania, $50 \mathrm{f} \ldots .$. Particularly suitable for decorating; the ash coiores foliage keeping the connate shape even when old.

"Eucalyptus robusta, Australia, 100 f.......... There ralled "swamp gum," for its affecting marshy plrces. Here it does well even in dry soil, without ettauing. of course, its full size, and has been much planted of late as an avenn e tree, for which purpose it is admirably snited.

Eucalyptus rostrata, Australia, $200 \mathrm{f}$........

The "red gum," somewhat harilier than E. glouulus: wood possessing higher calorific nower.

"Eucalyptus rudis, Australia, 60 f....

Siands droingt better than many others oud promises to make a beautiful avenue tree; young growth of copper colcr.

Eucalyptus viminalis, Southeast Australia, $300 \mathrm{f}$. One of the largest and quickest growing; produces also a kind of manna or sugar.

*EUPHORBIACEA species, Central Africa, $50 \mathrm{f}$. A rapid grower; bruad roundish leaves; flowers white in panicles, showy; appears quite hardy here.

"FICUS BENGALENSIS, India, $100 \mathrm{f}$. . . .. The proper "banyan tree." well kuown for the tendency to seud down aerial roots from its branches that will strike in to the grollind and form new trunks; a moist, warm situation favoring its growth; leaves hroadly oval, coriaceous with prominent veins, of a beautiful copper color when developing.

**Ficus Chauvieri. New Caledonia, $60 \mathrm{f}$........

Having the habit of $\mathrm{F}$. elastica, but with broader leaves more oval shaped. 
*FICUS CUNNINGHAMII, Queensland, 80 f. . \$

A large robust tree said to be the handsomest of all Australian Rubbers.

**Ficus elastica, India, $60 \mathrm{f}$.

50 to 100

The true "rubber tree" mentioned already under economic plants.

*Ficus glomerata, India and North Australia, $70 \mathrm{f}$. Mentioned already as the above, makes a dense shade tree, its leaves haring a most peculiar metallie lustre.

*FICUS INFECTORIA, India, $60 \mathrm{f} \ldots \ldots \ldots$ Consiciered to be one of the finest shade trees, with long, dark green, glossy leaves.

*Ficus macrophylla, Queensland, $100 \mathrm{f} \ldots . . .$.

The "Moreton bay fig," a large and magnificent, wide spreading tree; much planted in Southern California, where it appears quite at home, although for some unknown reason it does not perfect seed.

*FICUS OPPOSITIFOLIA, India, $50 \mathrm{f} \ldots . . .$.

A slower growing kind, with ruvid leaves, said to be used for polishing wood.

*FICUS PALMERI, Northwestern Mexico, $30 \mathrm{f}$. Mentioned under ecınomic plants, apparently liking hot and dry places.

*FICUS PRINCEPS, Brazil, $60 \mathrm{f}$...

25 to 100

25 to 100

25 to 100

Having magnificent foliage, bronze and copper colored when young,

*FICUS RELIGIOSA, India, $100 \mathrm{f} \ldots \ldots \ldots \ldots$

The "peepul," sacred to the Hindoos, who believe it embodies the divine triad-Vishnu. Brahma, Shiva. Leaves shining, suspended to long, flexible petioles, so that the slightest breeze will start them into movement, with a very distiuct rustling sound.

*FICUS RETUSA, India, $80 \mathrm{f} \ldots \ldots \ldots \ldots . . .$.

Very hardy and dense growing, leaves small, dark green, shining, rhombiform in shape; will make a capital at reet tree.

*Ficus rubiginosa, Australia, $100 \mathrm{f}$. . ......

Perhaps the hardiest kind, aud emitting very freely aerial roots; leaves thick; coriaceous, rather small, covered with a rusty tomentum underneath. A few large specimens are to be seen in Los Angeles and Santa Barbara. All above kinds of Ficus will prefer deep rich soil with plenty of moisture; but still adapt themselves tolerably well to dry places. 
FRAXINUS VELUTINA. Arizona, 40 f...... \$ 25 to 100 A quick growing, graceful, deciduous tree, most suitable for street planting, and well enduring drought.

*GMELINA ARBOREA, India, $60 \mathrm{f} \ldots . . . . .$. 100

*GMELINA ASIATICA, India, $60 \mathrm{f} . . . \ldots \ldots \ldots$

*Gmelina Rheedii, Ceylon, $30 \mathrm{f}$............

Ail of them handsome ornamental trees; flowers showy, whte or cream colored; timber similar to "teak" belonging to the same order Verbenaceae.

*Grevillea robusta, Australia, $150 \mathrm{f}$. . . . . . . . . Called also "silk oak," very much planted in California for the sake of its rapid growth, elegant fern. like foliage and beautiful orange flowers. Will stand well some frost and severe droughts, but is likely to have its limbs broken by wind.

*Grewia caffra, Natal, $30 \mathrm{f}$.... . . . . . . . .

Growing bushy, almost ever blooming, flowers star shaped, pink.

*HEMICYCLIA AUSTRALASICA, Q u e e ns land. $40 \mathrm{f} \ldots \ldots \ldots \ldots \ldots \ldots \ldots \ldots$

A spreading tree with beatiful holly-like leaves and red fruits.

Ilex latifolia, Japan, $30 \mathrm{f} \ldots \ldots \ldots \ldots \ldots \ldots$

A beautiful evergreen with glossy, ovate leaves nearly as large as those of Ficus elasrica. Will stand a good deal of frost.

*Jacaranda mimosaefolia, Brazil, $40 \mathrm{f}$

A most desiraule medium sized tree, with elegant feathery foliage and beautiful pauicles of blue flowers pioduced quite freely. Frequently planted iu southern Calif suia. where it is quite hardy.

Juglans nigra, Central States, 100 f... . . . . .

American Black Walnut; a magnificent tree; wood very valuable; prized also for its fruits.

*Juniperus Barbadensis, West Indies, 50 f . . . . Compact growing; wood very valuable.

Juniperus occidentalis, California, $30 \mathrm{f}$....... Doing well in the poorest soil.

JUNIPERUS PHOENICEA, Mediterranean

basin, $30 \mathrm{f} \ldots \ldots \ldots \ldots \ldots \ldots \ldots \ldots \ldots \ldots \ldots \ldots \ldots$

25 to 100

25 to 100

25 to 100

25 to 200

Growing quite compact and of dark green color; an invaluable plant for stauding heavy sea winds and the actual spraying of salt water. 
JUNIPERUS PROCERA, Abyssinia and Central\$

Africa, $150 \mathrm{f} \ldots \ldots \ldots \ldots \ldots$

A tall tree assuming with age the habit of the Cedar of Lebanon, extending in the higher mountains of Central Africa, and recently discovered on Kilimandjaro; estimated to be hardy enough at Berlin, Germany; its wood having the same properties as the Virginia or Bermuda cedars used in the manufacture of pencils.

Koelreuteria paniculata, China, $25 \mathrm{f} \ldots \ldots \ldots \ldots$ A small tree with finely cut foliage and pretty panicles of yellow flowers.

${ }^{*}$ Kydia calycina, India, $25 \mathrm{f} \ldots \ldots \ldots \ldots \ldots \ldots$.

50 to 100

Allied to Hibiscus; flowers white and pink in long panicles.

"Leucadendron argenteum, Cape, 30 f. ......... The celebrated "silver tree," native only of Table Mountain, at the Cape of Good Hope, and not easily grown elsewhere, with exception perhaps of Southern California, where it generally does remarkably well. Has ripened seed in Montecito.

Leucophyllum Texanum, Southern Texas, 25 f. . Not less white than "dusty miller"; rers pretty penstemon-like, lavender flowers.

Libocedrus decurrens, California, $200 \mathrm{f}$....... The "red cedar," one of the handsomest of our Conifers; some fine specimens to be seen in Santa Bar. bara.

Liriodendron tulipifera, Southeastern $\mathrm{S}$ ta tes,

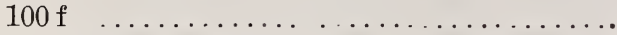

The "tulip tree," to be sure one of the handsomest of American trees. Needs rich deep soil, and plenty of moisture.

LYONOTHAMNUS FLORIBUNDUS, Islands of

the Santa Barbara Channel, $50 \mathrm{f} \ldots \ldots \ldots 100$ to 200

This very remarkable tree, called "palo fierro," or "irou wood," has a straighttrunk generally trian gular at the base, and reddish, stringy bark that peels off from top to bottom; the young growth is covered with reddish hair and exhales aromatic odor: the glossy, evergreen leaves are finely cut like ferns, and every branchlet is crowned with a terminal umbel of white flowers 4 to 5 inches in diameter. Will make a fine pot plant wherever it cannot be grown in the open. 
MACH ÆRIUM TIPA, River Plate, $100 \mathrm{f} \ldots . . \$$ 25 to 100 A magnificent shade tree, with light elegant foliage and handsome flowers, yielding one of the rosewoods of Southern Bryzil. Likely to be quite at home in our Southern States.

Magnolia grandiflora, Southern Atlantic States, $150 \mathrm{f}$. Acknowledgeu to be the haudsomest evergreen tree belonging to the temperate zone, and too generally known to deserve description. Needs deep alluvial soil and plenty of moisture to attain its full development; here it lias become ever blooming.

MAYTENUS BOARIA, Chile, $100 \mathrm{f} \ldots . . . . .$. A beautiful evergreen tree, yielding much prized timber, deriving its name from the greediness cattle feed on its foliage. Like other Chilian trees, will do well on this coast.

Melia azederach, India, $40 \mathrm{f} . \ldots \ldots \ldots \ldots \ldots$.

Commonly known as "pride of India," and "pride of China"; the variety originated in Texas. "Texas umbrella" being more generally grown and known to evervbody.

*MICHELIA CHAMPACA, India, 100 f. . . . . . The "sampige" of the Hindoos who have a great veneration for it aud plant it frequently around pagodas and shrines; flowers large, pale yellow and strongly scented.

*OROXYLUM INDICUM, India, $30 \mathrm{f} . . . . .$.

50 to 250

25 to 50

25 to 200

Remarkable for the large size and striking form of its leaves, almost black flowers and long sword-shaped pods.

*Parkinsonia aculeata, Southwestern States and North Mexico, 30 f................. $₫$ thorny tree with feathery drooping branches and hundsome yellow flowers; admirable for hedges; thrives in the driest places and can stand much cold.

*PARKINSONIA TORREYANA, same region



Known in Northern Mexico as "palo verde," from the bright green color of its branches generally des. titute of leaves: stands drought even better than the preceding. 
Paulownia imperialis, Japan, $60 \mathrm{f} \ldots \ldots \ldots \ldots$

Very fast grower, with rich foliage similar to Catalpa: flowers in early spring, in huge panicles, lavender color, very fragrant.

PERSEA INDICA, Canary Islands, $80 \mathrm{f}$.

25 to 50

Handsome evergreen, belonging to the Laurel family.

*Pinus Canariensis, Canary Islands, $200 \mathrm{f}$......

A beautiful straight growing tree; gracefully drooping leaves; wood exceedingly resinous.

PINUS EDULIS, New Mexico, $50 \mathrm{f} \ldots \ldots \ldots . .$.

Mentioned already under economic plants.

Pinus excelsa, Himalaya, $150 \mathrm{f} \ldots \ldots \ldots \ldots \ldots$ A picturesque tree with very fine bluish ieaves; will stand much frost, but will not succeed in arid and rocky locations.

Pinus Halepensis, Greece, etc., 100 f . . . . . . . . . Thrives in almost any kind of soil; stands well drought and some frost; foliage of a peculiar light green color.

Pinus insignis, California, $100 \mathrm{f}$.

Commonly known as Monterey pine; hardly surpassed by any other as far as rapid growth and picturesque effect is concerned, and aduptability to different kinds of soil; planted quite extensively in parks in England and Southern Europe wherever not too cold for it.

*PINUS LONGIFOLIA, Himalaya, $100 \mathrm{f} \quad \ldots$. Probably the handsomest of piues in its young stage for gracefulness and length of its leaves; will endure drought, but not as much cold as the two preceding.

Pinus pinea, Italy, $70 \mathrm{f}$

Mentioned already under economic plants.

*PINUS SINENSIS, China, $60 \mathrm{f} \ldots \ldots \ldots \ldots \ldots$

Standing well severe drought and heavy winds.

PINUS TORREYANA, Southern California, $50 \mathrm{f}$

A very interesting species with large cones, growing in limited number only in the Island of Santa Rosa and at Del Mar near San Diego.

*PIPER EXCELSUM, New Zealand, 25 f. . . . . .

25 to 50

25 to 50

25) to 50

25 to 50

25 to 50

25 to 50

25 to 50

A bushy tree; leaves aromatic; closely related to the black pepper of commerce.

*PIPTADENIA CEBIL, River Plate, 100 f....

Fast growing, similar to Acrcias. 
Pircunia dioica, River Plate. 50 f.... . . . ... \$

Known also as Phytolacca dioica; the "Ombu" of the Pampas, being the only tree of any size growing there; very fast grower and will succeed in any kind of soil; wood spongy and worthless.

PITHECOLOBIUM BREVIFOLIUM, Southern

Texas and Northern Mexico, $25 \mathrm{f} \ldots . . .$.

Yative name "Juajillo," the whitish flowers much sought by bees. the foliage avidly grazed by cattle.

*PITHECOLOBIUM spec.,Lower California, $30 \mathrm{f}$. Native name "palo catre." used for furniture making. *PITTOSPORUM RHOMBIFOLIUM, Queens-

land, $80 \mathrm{f} . \ldots \ldots \ldots \ldots \ldots \ldots \ldots \ldots$ Quite remarkable: rhomboid glossy leaves; large umhels of white flowers in summer, followed by oval yeilow berries persisting through all winter and making it appear as if clothed in gold.

"Pittosporum undulatum, New South Wales, $70 \mathrm{f}$. Very dense growing, with undulated leaves and clusters of large, white. fragrant flowers in spring. Exceedingly suited also for tall hedges.

Populus pyramidalis, Europe, $100 \mathrm{f}$..........

The Lombardy Poplar; forming splendid avenues near Santa Barbara,

Populus Caroliniana, Western States, $80 \mathrm{f}$... The Caroline Poplar, of more spreading habit.

**PTEROSPERMUM ACERIFOLIUM, India, $100 \mathrm{f}$ ...........

A large tree; leaves broad, silvery underneath; flower: very large, white, fragrant.

Quercus agrifolia, California, $100 \mathrm{f} \ldots \ldots$.....

QUERCUS GARRYANA, Oregon, 100 f .. ...

*QUERCUS INCANA, India, 60 f...........

Quercus robur, Europe, $100 \mathrm{f} . \ldots \ldots \ldots \ldots \ldots$.

Quercus suber, Southern Europe, $60 \mathrm{f} \ldots \ldots \ldots$.

All above Oaks are evergreen with exception of second and fourth, and do remarkably well here, the European kinds growing much faster than in their native country.

*REEVESIA THYRSOIDEA, Southern China,

$25 \mathrm{f}$

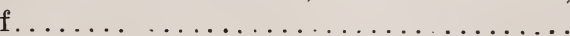

Leaves laurel shaped; showy white flowers in large nmbels. 
Salisburia adiantifolia, Japan, $100 \mathrm{f} \ldots \ldots \ldots \ldots \$ 100$ to 200

Known also as Gingko biloba, and Maiden hair tree; quite remarkable for shape of leaves and for size it attains in time.

Salix Babylonica, Asia Minor, 50 f.......... The "weeping willow," very popular here and keeping green until late in winter.

*Schinus molle, Peru, $50 \mathrm{f} \ldots \ldots \ldots$. . ........ The widely planted pepper, so much abused, but still remaining one of the best shade and avenue trees, and one of the few that will do well without any irrigation at all.

*SCHINUS TEREBINTHIFOLIUS, Brazil, $50 \mathrm{f}$ In Algeria and Tunis has proved preferable to the preceding for its more symmetrical growth and ampler foliage.

Sciadopitys verticillata, Japan, 15 ? f The "umbrella pine," so called not from the habit of the tree, but from the arrangemeat of its leaves iu whorls round the stem; a most remarkable tree that will staud much cold, but will not succeed in dry, hot places.

Sequoia gigantea, California, 4$): 1$ f ..........

The far famed "big tree"; needs deep soil and moisture.

Sequoia sempervirens, California, $390 \mathrm{f} \ldots . \ldots \ldots$ The "redwoud," with its congener S. gigantea to be cnnsidered, iudeed, as the glory of our native trees; this one possesses more adaptability to thrive in different soils, and is the only one among coniferous trees that will coppice well. In fact, most of the timber coming on the market now is from trees that were cut half a century ago on the first opening of this country.

*STENOCARPUS SALIGNUS, Australia, 30 f. 2 õ to 100

25 to 200

50 to 100 closely related to the famous "fire tree"; this one having greenish flowers.

*Sterculia acerifolia, New South Wales, 100 f...

The "flame tree," not uncommon in our gardens and thriviug in the dryest places where it will develop better its striking scarlet inflorescences.

*Sterculia diversifolia, East Australia, $90 \mathrm{f}$.....

Known alsn as "Brachychiton populneum"; growing somew hat in the style of the Lombardy Poplar; leaves euriously varying iu shape; flowers produced in great profusion, bell shaped, greenish white and red. 
*STERCULIA GREGORI, Australia, $100 \mathrm{f} \ldots . \$ 25$ to $10 \mathrm{~J}$ Considered to be only a form of S, acerifolia; growing more compact and pyramidal; flowers of sulmon color.

*STEREOSPERMUM SINICUM, China, 60 f.. .

*Stereospermum suaveolens, India, $80 \mathrm{f} . . . . .$. .

Two beautiful trees with rich compound foliage and fragrant flowers.

*SYNCARPIA LAURIFOLIA, Queensland,200 f

The "turpentine tree"; wood very durable, flowers white.

Taxodium distichum, Southeastern States, $200 \mathrm{f}$. The swamp or bald cypress of the Mississippi valloy; prefers being partially submerged in water; will grow in lagoons communicating with the ocean.

*Tristania conferta, Queensland, 15j f........

A beautiful shade tree with valuable timber, rich foliage and curiously frilled white flowers, here produced all the year round.

*WIDDRINGTONIA WHYTEI, Eastern Africa,

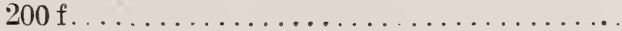

The "Mlanje cedar," a beautiful coniferous tree, discovered quite recently; timber very valuable.

\section{FLOWERING and ORNAMENTAL SHRUBS.}

"Legion" indeed is the name of those already introduced and more or less common in our gardens; but what a much larger number are still to be obtained from different countries! A selection of the most desirable, between old and new, is offered below, ranging from small trees to low shrubs, and to plants that, although herbaceous by birth, are assuming here half woody or suffrutescent habit. Every imaginable shade of color is represented among them, for everv 
season, while not a few have here become literally everblooming. It is impossible altogether to give hints for the culture of plants so widely differing in origin and in constitution; but at the end of this section will be found grouped together, such trees and shrubs that will best answer to special purposes, and, being of similar nature, will need similar treatment.

Abelia rupestris, China................\$ Graceful habit; shining leaves; flowers white, tinged with pink.

*ABUTILON LONGICUSPE, Abyssinia...... Quite a new departure amoug these popular shrubs; flowers open, lilac color, produced in long, well furnished terminal panicles. A good winter bloomer.

*Abutilon, best garden varieties.............

*ACACIA ACINACEA; A. armata; A. AURICULIFORMIS; A. BAILEY ANA; A. calamifolia; A. cultriformis; A. cyanophylla; A. CYCLOPIS; A. DIFFUSA; A. DODONAEIFOLIA; A. EXTENSA; A. FALCATA; A. GRANDIS; A. HARPOPHYLLA; A. HOMALOPHYLLA; A. juniperina; A. lineata; A. LINIFOLIA; A. longifolia; A. LUNATA; A. MONTANA; A. myrtifolia; A. OBLIQUA; A. RICEANA; A. salicina; A. SUAVEOLENS; A. TRINERVIS; A. verticillata.-All the above from Australia....

Highly recommendable shrubs, with gracelul habit; their flowers are yellow of every snade and generally fragrant, produced in great profusion either in round heads single or bunched together, or in catkins, and chiefly during the winter months. Many oi them are invaluable for cut flowers and not a few make admirable pot plants for growing in conservatories. Acacias take most willingly to any kind of soil, and will succeed withoutirrigation, making wonderful growth in a very short time; they will stand heavy winds and intense heat, but only a few degrees of frost. 
*Achania malvaviscus, South Texas and Mexico\$

Rapidly making wide spreading clumps, very effective for its light green leaves, vermilion flowers and white berries.

*Acokanthera spectabilis, South Africa ... A $\mathrm{m}$ 'dium sized shrub; dark coriaceous leaves and pretty umbels of pinkish white, sweet scented flowers.

*ADENOCAPPUS FRANKENIOIDES, Tenerife

Tall growing, broomlike shrub; all covered with yellow blossoms in spring.

ALBIZZIA NEMIU, Japan ..............

Perhaps only a diminutive form of A.julibrissin; flowers of more intense pink color.

*ALYXIA DAPHNOIDES, Norfolk Island .... A pretty evergreen shrub with shiny leaves and small bell shaped flowers similar to the "lily of the ralles."

*AMiCIA ZYGOMERIS, Mexico. . . ........

A small shrub with curious trifoliate leaves, and large pea shaped flowers yellow and red.

Amorpha fragrans, Eastern Atlantic States.... . Deciduous; curious bluish and yellow flowers in spikes.

Anisacanthus Wrightii, Southern Texas... ....

Dwarf growing. with linear leaves; covered all sum. mer with tubular red orange flowers.

ANTHYLLIS BARBA JOVIS, Italy .........

Elegant silver foliage; straw colored flowers; will stand the heaviest sea winds and grow under the sprays of salt water.

ANTHYLLIS HERMANNIAE, Greece....... Dwarf and compact growing; dark green foliage; myriads of small yellow flowers all summer.

*ARTEMISIA ARBORESCENS, Algeria....

Very effective for its silvery foliage; flowers light yellow.

ATRIPLEX BREWERI, Sea coast of Santa

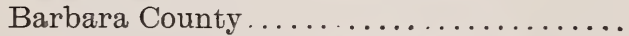

This is the much admired shrub so much used for hedges and tall borders \&bout Santa Barbara. Nothing will better stand clipping; the peculiar greyish color of its foliage harmonizes well with any other, and it will grow in the poorest soil and without water. 
Aucuba japonica, Japan .............. \$ 50 to 200

Very handsome shrubs with large coriaceous leaves and scarlet berries; there being several varieties, curiously dotted, striped or blotched with yellow. Will prefer partial shade.

Azara microphylla, Chile................

A very pretty evergreen with small glittering leaves and minute yellow flowers deliciously scented like vanilla.

*Bauhinia acuminata, India..............

Tall growing. spiny; flowers large, white.

*BAUHINIA DIPHYLLA, India...........

Same habit; fiowers larger.

*Bauhinia Galpini, Natal.

Growing more bushy and spreading over the ground; leaves smaller, dark green, setting out well the brick red flowers, at some distance looking like nasturtiums. Blooms from April to January at Santa Barbara.

*BAUHINIA GRANDIFLORA, Peru........ Vigorous growing; flowers very large, white.

*BAUHINIA HOOKERI, Queensland........ Growing quite tall; leaves small, red aish when young; flowers la rge, white edged with pink.

*Bauhinia purpurea, India ..... . . . . . . . . . Taller: leaves darker green and more coriaceous; flowers very showy, purplisls red and white, delicate. ly fragrant, looking very much like some choice orchids.

*BAUHINIA TOMENTOSA, Ceylon......... More delicate in all its parts; flowers very pretty, lemon yellow with a marooi blotch.

*BAUHINIA VARIEGATA, India........... Somewhat similar to B. purpurea, but more floriferous and the flowers having a lighter rosy look; a truly magnificent thing when in bloom.

Although introduced only recently, Bauhinias claim to be among the finest ornaments of southern gardens. Their curiously bilobed leaves, generally folding at night, attract attention, and such range of color there is in their showy fowers. 
Berberis aquifolium, Ca]ifornia............\$

Called by some "Oregon grape" and extending as far north as British Columbia; an invaluable shrub for growing under the shade of large trees; beautiful for its holly-like leaves, yellow flowers in trusses and bluish berries.

Berberis Darwinii, Chile and Fuegia. .......

This is a pretty dwarf kind with small leaves and pretty orange colored flowers, produced in great pro fusion.

*BERBERIS JAMESONII, Ecuador ........

Taller growing with larger leaves, silvery white underneath; flowers yellow.

BERBERIS PRUINOSA, Tibet.............

Very distinct, stems and under page of leaves mealy white; flowers sulphur yellow; berries white.

BERBERIS TRIFOLIOLATA, New Mexico

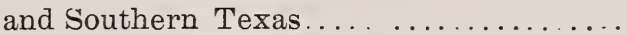

Only a few feet high; leaves biuish; flowers yellow; berries red, and pleasant to eat.

**BOCCONIA FRUTESCENS, West Indies....

A striking plant, with very large glaucous, lobated leaves: flowers small, greenish, in huge panicles.

*BOssiaEA RUFA VIRGATA, Australia....

Half trailing; very pretty pea shaped flowers red and yellow.

*Bouvardia, best garden varieties .........

These are most charming shrubs, flowering profusely, some of them fragrant; ranging from pure white to piuk, deep scarlet and light yellow.

**Bunfelsia americana, West Indies.... . . . . .

Flowers greenish yellow, fragrant.

**BRUNFELSIA NITIDA, Cuba...........

Flowers blue; dwarf growing.

*BUDDLEIA COLVILLI, Himalaya .........

The finest of the genus; the whole plant covered with bluish tomentum; flowers pink, in long spikes.

BUDDLEIA VARIABILIS, China..........

Newly introduced; flowers very pretty, of different shades of pinkish purple. 
Buddleia globosa, Chile.................\$

Erect growing, long dark green leaves white underneath, and sweet scented orange flowers in globular heads; quite striking clumps of it to be seen in Golden Gate Park, San Francisco.



An elegant shrub or small tree with drooping branches and pretty white flowers produced in summer.

Buxus sempervirens, Southern Europe.........

The well known "box" standing any sort of bad treatment and growing in any kind of soil.

* CADIA VARIA, Arabia............... Very pretty bell shaped, rose colored flowers.

*CAESALPINIA ECHINATA, Central America Spiny; leaves shining. copper color when young; flowers yellow, showy.

*Caesalpinia Gilliesii, River Plate........... Finely cut leaves, deciduous; flowers yellow and red; by some called the "bird of paradise flower," name given also to Strelitzia Reginae.

*CAESALPINIA MINAX, China............ Very thorny and slender growing.

*CAESALPINIA PANNOSA, Lower California Recently discovered by Mr. T. S. Brandegee; a very rapid grower; stems and leaves having a sort of waxy coating; flowers sellow.

${ }^{* *}$ Caesalpinia pulcherrima, West Indies.......

Known as "Barbadoes pride"; leaves bright green; beautiful flowers, varying from yellow to scarlet.

*Calceolaria rugosa, Chile ................

A low undershrub; flowers very pretty varying from yellow to maroon color,

*Calliandra portoricensis, Porto Rico.......... Acacia-like foliage, very finely cut; flowers large, pure white, sweet scented.

*Callistemon linearis, Australia ... . . . . . . .

*Callistemon rigidus, Australia.............

* Callistemon speciosus, Australia .... .......

Known under the common name of "bottle brush trees" on account of the appearance of their crimson or scarlet flowers; fast growers; will thrive in any soil and without irrigation. 
*CALOTHAMNUS QUADRIFIDUS, West Australia ......................\$

Somewhat similar to the above, but more graceful in habit; flowers scarlet.

*Calpurnia lasiogyne, Natal..............

The "Natal laburnum" from some resemblance to the European laburnum: flowers in elegant bunches, yellow, but of different shape, and without fragrance.

Calycanthus floridus, Eastern States .........

The well known allspice shrub or Pompadour.

Calycanthus praecox, China and Japan.... . . . The Japan allspice shrub; pretty waxlike fiowers, very fragrant, appearing in early winter. Very hardy.

CALYCOTOME VILLOSA, Italy. . ......... Much branched, spiny, covered with large, sulphur yellow, pea shaped flowers very early in spring.

Camellia Japonica, Japan ...............

The much admired Camellia, generally doing very well on this coast, without any partizular care. We can supply a selection of the best Europesn $\nabla$ arieties: detailed lists on application.

*Cantua buxifolia, Chile ... ... ..........

A small shrub; fluwers larye, of the most beautiful. crimson orange color.

Caryopteris mastacanthus, China...........

Wrongly called blue spiraea; pretty bluish flowers in summer; very hardy.

*CASSIA ARTEMISIOIDES, Central Australia Pretty silvery grey foliage, most finely divided; flowers deep yellow; will stand any amount of ärought and some frost.

CASSIA CORYMBOSA, River Plate.........

${ }^{*}$ CASSIA SCHINIFOLIA, Australia ........

*Cassia tomentosa, Mexico. . ...............

All of them with yellow flowers, very showy; the last being a yood winter bloomer.

*CEANOTHUS AFRICANUS, South Africa...

Leaves small, shining; flowers deep blue.

*Ceanothus spinosus, California..............

Stems and branches very slender, sea green, spiny; flowers ranging from sky blue to almost pure white. Continuously in bloom at Sants Berbara. 
*Cestrum aurantiacum, Guatemala .........

Flowers orange yellow.

*Cestrum diurnum, West Indies... . . . . . .

Flowers white, fragrant in the day.

*Cestrum elegans. Mexico.... ... ........

Flowers varying from crimson to scarlet.

*Cestrum nocturnum, Jamaica ..........

Fluwers greenish; deliciously scented at night.

*Chaenostoma bispidum, South Africa .... ....

Only one to two feet high, growing very compact, and covered all the year with tiny white flowers. It makes a capital pot and window plant.

Chilopsis saligna, Western Southern States and

North Mexico .....................

Called "desert willow" and "mimbres"; deciduous; leaves willow-like; flowers like a Bignonia, prettily fringed, purple and white.

Choisya ternata, Mexico

Very pretty and compact; much grown in France for florists' use; leaves trifoliate shining; pure white flowers in terminal umhels, slightly fragrant and looking like orange blossoms. Will stand some frost.

Chorizema ilicifolium, Australia ...........

Taller and more slender growing, with larger flowers.

*Chorizema varium, Australia ...........

Together with its congeners a great favorite in European conservatories; a low shrub, here ever blouming; flowers pea shaped, red and orange.

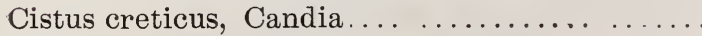

Cistus cyprius, Cyprus ... ... ... .......

CISTUS HETEPOPHYLLUS, Algeria.......

CISTUS PARVIFLORUS, Greece ..........

Commonly known as "rock rose"; dwarf aromalic shrubs; flowers large, rose shaped, white in the first, rose pink in the fourth, and purple in the other two; admirably adapted for rock work; prefer dry places and will stand some frost.

Citrus trifoliata, Japan ................

The same that is used so extensively in Florida for hardy stock to bud oranges on. Will make furbidding and impassable hedges, very attractive in the spring with its large snow white blossoms, and in fall and winter with its downy, deep orange fruits. 
*CLERODENDRON TOMENTOSUM, N e w South Wales.................... \$

A tall shrub; leaves velvety; flowers white in large corymbs.

Clianthus puniceus, New Zealand ...........

There called "parrot's bill"; an elegant half trailing shrub with feathery leaves and large brick red flowers; grows to perfection on this coast, as shown by the striking clumps in Golden Gate Park, San Francisco, there blooming all through the winter.

CONVOLVULUS OLEOIDES, Greece

A charming little shrub; stems slender, silvery, here covered all through the year with a profusion of salver shaped bright rose flowers. Ought to make a good pot plant.

Coprosma Baueriana, New Zealand ..........

Coprosma Baueriana, fol. var., New Zealand....

Trailing; with glossy leaves, in the second broadly patched with clear yellow; one of the very best among variegated plants.

*COMAROSTAPHYLIS DIVERSIFOLIA,San-

ta Cruz Island . . . . . . ...........

A distinct looking evergreen, related to Arbutus; flowers pinkish white in bunches followed by bright red berries.

Corchorus japonicus, Japan..............

A low dense shrub; light green stems aud leaves; double yellow flowers all the year round.

CORIARIA MYRTIFOLIA, Southern Europe.

A pretty, dense growing shrub; shiny foliage like myrtle.

CORONILLA EMEROIDES, Southern Europe.

Growing taller than the following; flowers yellow in drooping bunches like diminutive laburnum, or golden chain.

Coronilla glauca, Southern Europe...... . . . .

One of the most common shrubs in Southern California, bearing its pretty yellow flowers all through the year.

Coronilla glauca variegata, garden origin ......

One of the prettiest variegated low shrubs.

CORONILLA JUNCEA, Southern Europe....

Low growing; fine rush-like stems; flowers yellow; suitable for rockeries. 
*CORONILLA VIMINALIS, Algeria. .....\$

This hai a more trailing habit and more glancous leaves harmouizing beantifully with the charming white and pink flowers produced all the year round. Admirable for cut flowers, and likely to become a good florists' plant.

Crataegus pyracantha, Southern Europe .......

Sometimes ealled the burning bush from the bright orange color of its numberless berries standing through the winter. One of the best plants for herges.

* CRYPTOLEPIS LONGIFLORA, India ....

Dwarf and compact growing with long leaves tinted with red; tubular white flowers as in Bouvardia jas. minitlora; sure t.o make very nice pot plants.

Cydonia japonica, Japan $\quad \ldots \quad \ldots \quad \ldots \quad \ldots . . . \quad \ldots$

The flowering Quince; one of the brightest fl owering shrubs for winter and early spring, ranging in color from scarlet to white; very hardy.

Cytisus albus, Portugal ................

CYTISUS ALBUS INCARNATUS?........

First white flowering; second having flesh colored flowers.

CYTISUS ATLEY ANUS, Europe ..........

CYTISUS CAPITATUS, Europe $\quad \ldots . \ldots \ldots$

CYTISUS EVERESTIANUS, Europe ........

${ }^{*}$ CYTISUS FORMOSISSIMUS, Spain ? ......

All four yellow tlowered.

*CYTISUS GLABRATUS, Portugal... . ......

Growing somewhat in the style of the so-called Spanish broom; flowers larger, yellow, delicately penciled red.

${ }^{*}$ Cytisus linifolius, Spain................

Silvery foìage; yellow flowers.

*CYTISUS PALMENSIS, Canary 'Islands .....

Stems and branches erect, threadlike; from November to June covered with thousands of pure white, deliciously scented flowers; first rate for pot growing as well as for cut flowers.

*Cytisus proliferus, Canary Islands...........

Preconised some years ago as a fodder plant under the vame of "tagasaste"; a very rapid grower; flowers rather large, white, fragrant. 
Cytisus racemosus, garden hybrid ?.........\$

Flowers yellow in terminal spikes; mich used as a pot plaut in the east.

Cytisus scoparius, Northern Europe.... .... .

The commonly called Scot $\cdot h$ broom; stands a good deal of cold.

Cytisus scoparius Andreanus, garden variety....

Originated in France, flowers beautifully blotched red and yellow. Known also as Genista Andreana.

*Dais cotinifolia, South Africa ...........

Tall erect shrub; leaves round, light green: flowers rosy pink in globular heads.

Daphne odora, China and Japan ............

Daphne odora rubra, China and Japan.........

Daphne odora variegata, China and Japan ......

The white flowered Daphne and varieties with pink flowers and variegated leaves are to be sure among the most desirable shrubs for winter blooming, and on this coast do admirably well even in full sun.

*Datura cornigera, Brazil................

*Datura suaveolens, Mexico.............. .

Commonly called "floripondia" and "angel's trumpet," from the shape of their large white flowers exquisitely fragrant, chiefly at night; very popular plants here, and everblooming.

*Datura sanguinea, Peru.

More slender growing, flowers large, orange yellow, scentless

*Diosma fragrans, Cape of Good Hope ........

Popularly known as "breath of heaven," a great fav. orite here; makes also very nice pot piants.

*DIOSMA PURPUREA, South Africa .......

Only one to two feet high, bushy, all covered with light purple flowers in early spring.

*Duranta Ellisiae, South America...........

Not spiny; flowers lighter colored; berries larger than the following.

*Duranta Plumieri, South America..........

An elegant shrub, literally covered with pretty blue flowers in summer, followed by bright yellow berries persisting for several months, and very ornamental.

*Duranta Plumieri fl. albo...... . . . . . . . .

A pure white variety of the same, very pretty, 
DUVAUA DEPENDENS, Chile ..........\$

Dark gree!l aromatic leaves, flowers whitish.

EDWARSIA CHILENSIS, Chile ... . ...

EDWARSIA GRANDIFLORA, New Zealand. .

EDWARSIA MACNABIANA, New Zealand...

25

EDWARSIA MICROPHYLLA, Chile .......

All with pretty folinge, and large. yellow, pea shaped flowers.

*EREMOPHILA LONGIFOLIA, Australia ...

Pretty and distinct looking, allied to Myoporum.

Erica fragrans, Southern Europe ... . . . . . .

Pretty white flowers all winter.

Erica mediterranea, Southern Europe ........

The well known "heath," bearing a profusion of small, light pink flowers.

Erica Wilmoreana, garden hybrid... ........

This has fussy stems and leaves and very pretty rosy

tubular flowers, produced almost all the year round.

Erythrina cristagalli, Brazil $\ldots \ldots \ldots \ldots \ldots \ldots$

Erythrina herbacea, Florida...............

*Erythrina speciosa, West Indies....... ....

- smaller yrowing "coral trees," blooming well if cut back every year; all of them with dazzling vermilion flowers.

Escallonia Berteriana, Chile ...............

Escallonia floribunda, South America... ....

*Escallonia organensis, Brazil.... ... ......

Escallonia rubra, Chile ... .............

All of them vigorous and spreading, with viscous brane hes and leaves exhaling a peculiar odor: flowers very profuse, white in first and second, rose in third, and red in the fourth.

*Euphorbia fulgens, Mexico ..............

Stems gracefully arching, with gay green leaves; flower bracts bright scarlet.

*Euphorbia pulcherrima, Mexico

Popularly known as "Poinsettia" and in Mexico as "flor de pascua," for its being at its best for Christmas.

*Euphorbia pulcherrima plenissima, garden

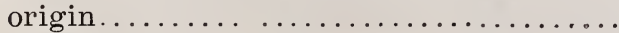
A monstrous double form of the above. 
*Euphorbia splendens, Bourbon Island . . . . . . \$

Spiuy, everblooming, most effective for rock work.

All three will do better in the hottest alld sunniest places.

EVONYMUS FIMBRIATUS, Himalaya .......

Tall regular growing; a very pretty ald distinct locking everyreen.

Exochorda grandiflora, China............

The correct name for Spiraea graudiflora. one of the prettiest winter blooming shruos; doing admirably on this cnast.

Fabiana imbricata, Chile................

There growing at high elevation and in dry places, a pretty shrub, quite popular here, oftell mistaken for an Erica, on account of both its leaves and of its white tubular flowers.

*FLEMINGIA CONGESTA, India

Rich ornamental folinge; flowers purple.

FONTANESIA PHYLLIRAEOIDES, North



Low and bushy; pretty yellow flowers all summer.

*Fuchsia arborescens, Mexico..............

Known also as F. syringaeflora, for the resemblance of its flower bunches to the common lilac; a truly beautiful plant, excellent for winter blonmiıg.

*Fuchsia corymbiflora. Peru... . . . .......

Large light green leaves; long scarlel flowers in bunches.

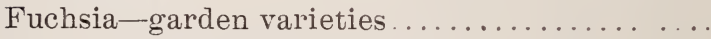

A selection of the vers best of this most popular shrub, quite at home on our coast, and eacily grown.

*Gardenia citriodora, Natal...............

Low growing, flowers wlite, lemon scented.

*Gardenia florida, China... . . . . . . . . . .

Wrongly called "Cape Jusmine"; flowers double, white. powerfully scented.

*GARDENIA ROTHMANNI, Natal.........

*GAPDENIA THUMBERGI, South Africa...

Dwarf growing; the first with pale yellow, the second with white flowers.

*GENISTA ANCISTROCARPA, Portugal..... leaves; flowers yellow. 
GENISTA ÆTHNENSIS, Sicily .........\$

Arborescent; flowers sulphur yellow in summer; will endure much frost.

*Genista canariensis, Canary Islands . . . . . . .

Grown a good deal for early blooming; flowers yellow, fragrant.

*GENISTA EPHEDROIDES, Spain. ....... Summer bloomer; flowers deeper yellow than any other.

*GENISTA FEROX, North Africa ... . . . . . .

*GENISTA FLORIDA, Spain ............. $2 \tilde{a}$

*GENISTA HILDEBRANDI, Canary Islands.. 25

Tall growing; woolly; flowers yellow.

*GENISTA MADERENSIS, Madeira.........

All with yellow flowers and early blooners.

*GENISTA MARTINI, Canary Islands.......

*GENISTA MONOSPERMA, Sicily..........

Dwarf, trailing, flowers large, white with a crimson blotch, and deliciously fragrant; sure to make an excellent pot plant.

*GENISTA SPHAEROCARPA, Spain ......

Sometimes confused with G. monosperma, from which it is distiuct; growing taller and more compact; with more silvery stems destitute of leaves, and small yellow flowers.

*GENISTA UMBELLATA, North Africa .....

*GENISTA VIRGATA, Madeira. ..........

Both yellow flowered; the second considered as the best of yellow flowered species at Kew.

*GLOBULARIA ALYPUM, Greece.... .... .

A low shrub covered all winter with globose heads of bright blue flowers.

*GOODIA LOTIFOLIA, Australia

Dwarf; glaucous leaves; flowers liarge, pea shaped. yellow.

*GORDONIA ANOMALA, Hong Kong ... . .

A pretty evergreen with showy cream colored flowers; very choice.

*GOSSYPIUM DAVIDSONI, Lower California

Woody, with beautiful yellow flowers.

*GRABOWSKIA GLAUCA, River Plate...... 
*GYMNOSPORIA SERRATA, Himalaya .....\$

A pretty evergreen spiny shrub; suitable for hedges.

*Gynura aurantiaca, Java ... ..........

A very remarkable soft wooded plant; stems, leaves and particularly the new growth, clothed with dense violaceous fur; numerous orange flowers.

*HAKEA CUCULLATA, Australia .........

*HAKEA LAURINA, Australia .. . ...... .

Tall growing; leaves (phyllodes) large; flowers very pretty, red and white in winter.

*Hakea pugioniformis, Australia .... ......

A most curious looking plant; at some distauce simulating a pine; flowers whitısh.

*HAKEA REPANDA, Australia...........

*Hakea saligna, Australia .... . . . . . . . . .

Erect and bushy: leaves willow-like;flowers in spikes, white, very pretty.

*HAKEA ULICINA, Australia ............

Foliage similar to the Eurupean furze; fiowers white.

All Hakeas are among the best evergreens, standing abuse and severe drought, but not much cold.

*HALLERIA LUCIDA, South Africa ........

A pretty shrub of graceful habit; elegant shining leaves and reddish flowers.

HALIMODENDRON ARGENTEUM, Siberia .

A prickly, glaucous shrub, with pretty pea shaped pink flowers in summer; will stand alike drought aud coid and thrive even iu saline or alkaline soil.

*Hamelia patens, from Florida southwards.....

A pretty shrub; heads of reddish flowers all the year.

*Hardenbergia monophylla, Australia ........

*Hardenbergia monophylla alba, Australia.. . .

Very pretty winter blooming shrubs; the first with purple, the second wita pure white, pea shaped flowers, in graceful bunches; first rate also for florists' use.

*HELICHRYSUM DIOSM EFOLIUM, Aus-

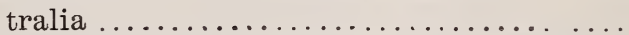

Tall and symmetrical growing, with minute foliage and terminal heads of small, white everlasting flowers.

*Heliatropium peruvianum, Peru ... ........

The universally favorite Heliotrope, attaining gigantic size in Southern California. and blooming without intermission. 
*Heterocentron mexicanum, Mexico...... ...\& $\$$

Dwarf and bushy, covered all the year with pretty. pinkish white flowers.

*Hibiscus chrysanthus, South America ?.......

Dwarf and bushy; foliage dark green: flowers $2-3$ in. diameter, bright lemon yellow.

*Hibiscus Denisoniae, garden origin ?.........

A small shrub; flowers delicate rose color. very pretty and distinct.

*HIBISCUS HETEROPHYLLUS, Queensland

Tall growing, rich, variously shaped foliage; large white flowers with deep crimson eye, very showy and free bloomer.

*Hibiscus manihot, Southern China.........

Tall growing; deeply cut foliage; flowers up to six in. diameter, light yellow with maroon center; exceedingly showy.

*Hibiscus mutabilis, India ..............

Growing to the size of a small tree; flowers large, curiously changing in color at different hours of the day.

*Hibiscus rosa sinensis, South China..........

A selection of the choicest single and double varieties of this showy shrub, so popular in Southern California.

*Hibiscus schizopetalus, Southern China? ..... Very distinct and handsome; flowers orange scarlet. in great profusion, hanging down from the branches.

*HIBISCUS SPLENDENS, Austra]ia........

Flowers very large of a beautiful pink color.

Hibiscus syriacus. Eastern Asia ........ .

The harãy deciduous kiud, knowll also as "Althaen frutex" aud "Rose of Sharon" in this conntry, of which numberless varieties are offered; quite recommendable for locations where the more showy tropical kinis caunnt be grown in the open.

Hydrangea hortensis, Japan ..............

Common Hydrangea, a general favorite on this coast where it thrives to perfection even in full sun.

Hydrangea Thomas Hogg, garden origin......

Pure white flowers.

Hydrangea paniculata, Japan ....

Flowers white in very long panicles. 
HYMENANTHERA CRASSIFOLIA, Australia and New Zealand. . ............. \$

Low and bushy evergreen; leaves round, glosss; flowers yellowish; berries white.

*HYMENOSPORUM FLAVUM, Queensland. .

Allied to Pittosporum : tall growjng; leaves large.dark green; flowers lemon yellow, very showy.

"HYPERICUM FLORIBUNDUM, Madeira ...

Tall growiug; light green leaves; yellow flowers.

ILEX BALEARICA, Balearic Islands . . . . . . .

A southeru form of the European Holly, likely to thrive better ou our coast.

INDIGOFERA AUSTRALIS, Australia .......

*INDIGOFERA DECORA, China...........

All of them pretty, low growing shrubs, very profuse bloomers; flowers pea shaped, purple, in spikes.

*INGA ANOMALA, South America... .....

*INGA PULCHERRIMA, Mexico...........

Both medium sized shrubs; pretty, acacia-like foliage; in large tassels, the first blu ish and yellow, the second scarlet.

*Iochroma fuchsioides, Ecuador ............

*Iochroma lanceolatum, South America.......

Both tall growing and very ornamental; the first with scarlet, second with indigo blue flowers in bunches; here everblooming.

Ipomaea fistulosa, River Plate .... ........

Shrubby with fleshy stems; large purple pink flowers in autumn.

*Iresine Herbsti, South Brazil......... . . . . Known also as Achyranthes Verschaffelti; a capital plant for hedding out; also for growing with ferus and other foliage plauts; stems and leaves keeping well their peculiar res color summer and winter.

*Ixora stricta, South China..... . . . ...

Handsome evergreen foliage; flowers orange.

*Jacobinia magnifica, Brazil .............

Bushy growing with broad leaves; waxy tubular scarlet flowers in panicles.

*.Jatropha multifida, South America..........

Very ornamental for its curiously divided leaves and graceful habil. 
KAGENECKIA OBLONGA, Juan Fernandez. .\$

Pretty, finely cut, glossy foliage; flowers white.

LABURNUM ADAMI, garden hybrid ........

A remarkable sport from the European laburnum, comiug true from seed; flowers in large trusses some yell..w, some purple, on same plant. Like the follow ing will stand severe frost.

LABURNUM VULGARE PARKSII, garden hybrid..................... An improved variety with much larger bunches of flowers than common laburnum.

Lagerstroemia indica, North India and China.

Deciduous, tall growing aud standing mauy degrees of frost; in this country knowu as "crape myrtle," beautiful for summer blooming; flowers crimson, purpie or white, according to variety.

*\%A GERSTPOEMIA FLOS REGIN Æ, India. Nuch larger growing and more gorgeous blooming, but very tender.

*Lagunaria Patersoni, Norfolk Island .... ... Evergreen, pyramidal growing; large, Hibiscus-like, pinkish white flowers.

*LANTANA PURPUREA, Paraguay .... .... Erect growing, not prostrate; flowers purple, very pretty.

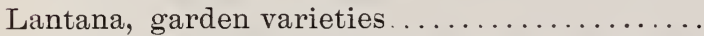
Quite common, but very useful for dry places, hedges and slopes; colors exceeding varied.

Laurus nobilis, Southern Europe $\ldots . . \ldots$. . . The classical "laurel" or "sweet bay," a beautiful evergreen, standing drought and many degrees of frost.

Lavandula dentata, Southern Europe ......... Quite distinct and pretty foliage; flowers deep purple.

LAVANDULA STECHAS, Southern Europe. . Low growing and aromatic like the following; dark purple flowers in terminal heads.

Lavandula vera, Southern Europe ........... Common lavender, one of the most popular plants, excellent for borders and dry places, and standing cold well. 
LAVATERA ASSURGENTIFLORA, Southern California ..................\$

Very fast grower; dark green foliage; flowers red; one of the best plants to stand saline winds.

*Leonotis leonurus, South Africa .......... .

The "lion's tail," very showy for its orange flowers in whorls, here produced all the year round.

*LEPTOSPERMUM FLAVESCENS, Australia

*Leptospermum scoparium, Australia .........

Middie sized shrubs, with pretty flowers all along the stems, first and second white, third lilac; this last being the one known as "Australian tea"; all stand dronght well.

LEPTOSYNE GIGANTEA, Santa Cruz Island.

Stout whitish trük. crowned with feathery leaves; bright yellow, sweet scented flowers in lateral umbels; a striking plaut for lawns, as also for pot culture.

"Leucaena glauca, Southern Texas, West Indies,

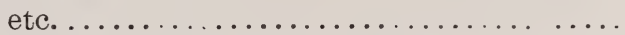

In Florida known as white popinac; a very rapid grower; elegant acacia-like foliage, and whitish flowers.

*Libonia floribunda, Brazil ................

A very pretty dwarf sirub well adapted for pot growing, but here doing finelv in the open; during winter covered with tubular, scarlet and yellow flowers.

Lippia citriodora, Peru and Chile . ........... The most popular "lemon verbena," on this coast growing to very large size; known also as "Aloysia citriodora"; will stand some frost.

*Lobelia laxiflora, Mexico...... ........ .

The correct name for Siphocampylus bicolor; a pretty low bush with red tubular flowers.

Lonicera Alberti, Turkestan..............

A small shrub, not climbing; fine sea green leaves; flowers of a very pretty rose color.

*Lopezia coronata, Mexico . . ............

A pretty, small, half sinrubby plant, with curious flowers, purplish or white; in Europe very much used for light bouquets and table decoration. 
*LOTUS AUSTRALIS, Australia ........... .

A small dense shrub; flowers pink.

*Lotus Jacobaeus, Cape Verde Islands.

A pretty, half shrubby plant, here covered all the year with its curious velvety, almost black, pea shaped flowers.

* Mackaya bella, Natal .................. . Leaves glnssy; flowers large, funnel shaped, lavender color.

MALLOTUS JAPONICUS, Japan...........

A small tree with pretty foliage: flowers pule yellow.

Magnolia fuscata, China. ..............

Tall shrub or small tree, compact growing; pretty foliage; flowers rather small, not shows, but exquisitely fragrant; by some in this country called "banaua shrub."

MARGYRICARPUS SETOSUS, Peru and Chile

Low growing, pretty heather-like foliage, and small white berries; very good for rock work.

MEDICAGO ARBOREA, Southern Europe ...

"Moon trefoil" and "iree alfaifa"; stems woody, center as black and hard as ebony; foliage bright green, flowers orange yellow, produced nearly all the year round.

Melaleuca decussata, Australia............. Lilac flowers.

Melaleuca leucadendron, Australia ..........

Larger growing; trunk and branches with white bark peeling off; flowers white.

Melaleuca hypericifolia, Australia ... . . . . . . .

Leaves broader than in the preceding; flowers bright scarlet.

MELALEUCA MICROMERA, Australia .....

Leaves very minute, embracing the branchlets, curiuusly looking like some juniper; flowers sulphur sellow. All Melalencas or "bottle brush trees," as they are sometimes called from the arrangement of their flowers in a sort of cylindrical brush, are great blnomers and precious indeed for standing winds a ud drought; will also endure some frosts.

**IELASTOMA CANDIDUM, India.........

Both having pretty foliage; showy flowers, white in the first. red in the second. 
Melia semperflorens, Asia ... . ........\$

Dwarf growing species similar to the so-called "pride of India"; flowers lilac, fragrunt, all the year round.

Melianthus major, South Africa

Melianthus minor, South Africa .... ... ... .

Both with very ornamental foliage and strange looking flowers, brow dish in the first, dark brown in the second; each of them secreting a large quantity of honey-like liquid, from which their name is derised.

*MIMOSA ACANTHOCARPA, South America

All spiny and with acacia-like finely cut leaves, exreediug:y sensitive iu the second; flowers light purple in globular heads.

Muhlembeckia platyclada, Solomon Islands.... . A remarkable plaut with flattened stems and leaves looking like varnished; small waxy whitish flowers on the edges of the leaves; excellent for shady places and one of the most enduring house plauts.

**Murraya exotica, India $\ldots \ldots \ldots \ldots \ldots$. Quite pretty and refined looking; foliage dark green, finely cut; flowers white in panicles, similar in shape and smelling like orange blossoms.

MYOPORUM ACUMINATUM, Australia.... .

Myoporum laetum, New Zealand .......... Myoporum verrucosum, Australia? . .........

Quick growing, with shining leaves as if perforated with translucid dots; pretty white flowers and purple berries.

All ilyoporums are suitable to plant along the seashure, and will do well without irrigation.

Myrtus communis, Southern Europe..........

The classic "myrtle" onee sacred to Venus; its pretty white flowers being produced here all the sear round.

Myrtus Luma, Chile .............. ....

Known also as Eugenia apiculata; flowers larger than the above, very pretty.

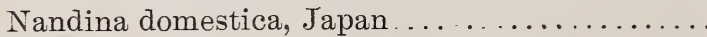

A small shrub with pretty, feathery foliage, the new growth tinted with red; small white flowers in large panicles, and red berries. 
Nerium oleander, Souchern Europe..........

The well known Oleander, thriving best in moist ground; can be supplied in several varieties.

*OLEA CHRYSOPHYLLA, India ?......... Leaves golden color underneath.

*Oncoba Kraussiana, Natal ...............

Glossy leaves and white flowers; seeds used as ornaments by the natives.

Osmanthus aquifolium, Japan ............. Very pretty evergreen; coriaceous spiny leaves like holly: fluwers larger than the following, pure white, smelling like Gardenia.

Osmanthus fragrans, Japan and China.... ....

Leaves less coriaceous and not spiny; flowers small. yellowish, not showy, but exhaling a most powerful and yet deiscate perfume.

*OSTEOMELES ANTHYLLIDIFOLIA, Malesia and Hawaii ................... Very interesting and pretty; having the silvery pinuate foliage of Anthyllis barba-Jovis, while belonging to the Rose family.

*OXYLOBIUM CALLISTACHYS, Australia...

A very pretty shrub; leaves light green; flowers in well furnished spikes, bright yellow.

*PELARGONIUM ECHINATUM, South Africa A spiny shrub with pretty flowers changiog color at different hours of the day.

*Pelargonium, garden varieties............. 
PHLOMIS RUSSELLIANA, Asia Minor ... \$

Foliage and flowers larger, and more spreading over the ground; a ennstant bloomer.

*Pimelea decussata, Australia..............

*PIMELEA LIGUSTRINA, Australia.... ... .

Exquisitely pretty shrubs, of eompact growth, first with pink, secund with white flowers, doing very weli on this coast.

*Pittosporum crassifolium, New Zealand.... . . .

Pyramidal growing; leaves glaucescent; flowers chocolate purple.

*PITTOSPORUM PHYLLIRAEOIDES, Aus-

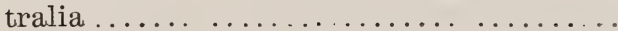

Habit of weeplug willow; flowers solitary, yellow; berries oval, compressed, yellow; a striking plant, that will do well in the driest places, being a native oi the deserts in the interior of Australia.

*Pittosporum tenuifolium, Australia ..... ....

Leaves sea green, shining; hranchlets blackish as well as the flowers; cumpact and symmetricalgrowing.

*PITTOSPORUM TETRASPERMUM, India..

Very rich foliage, silky white in the new growth; flowers yellowish, fragrant.

Pittosporum tobira, China and Japan.........

Rather dwarf and compact, leaves coriaceous, deep green; flowers pure white, very fragrant. will stand some frost, and is also suitable for pot culture.

*PITTOSPORUM VIRIDIFLORUM, S o u t h

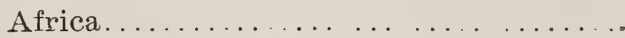

Flowers greenish, exquisitely fragrant.

For other Pittosporums of larger size see under Trees.

*PLECTRONIA SPINOSA, South Africa.....

Spiny; leaves shining - flowers white.

Pleroma macranthum, Brazil. .............

Slender growing, the large deep violet flowers appearing mostiy on top of shoots; a beautiful plant, doing very well on this coast as far north as San Francisco,

*PLUMIERIA ACUMINATA, tropical America

*PLUMIERIA HYPOLEUCA, tropical Amer-

ica.........................

Both with fleshy stems, dark green leaves and large white flowers in umbels, exquisitely fragrant; known also as "frangipani"; will thrive in the hottest places; to be kept dry in winter. 
*POD.1LYRId SERICEA, South Africa ......\$

Leaves silky when young; large, pea shaped, rose colored flowers in spring.

**Poinciana regia, Madagascar

In West Indies known as "flamboyant"; very elegant foliage; flowers bright and scarlet in large panicles; will succeed only in very warm places and will stanc? no frost.

*Poinsettia-see above under Euphorbia.......

*POLYGALA APOPETALA, Lower California One of the best of our introductions: grows tall and bushy; every branch ending in a spike of large fragrant haif yellowish and half purple flowers that change to uniform purple the secoud cay; the winged seed pods are also very interesting. This plant may also have some economic value for the large amount of oil contained in the seeds quite abundantly produced.

*Polygala myrtifolia, South Africa........... A very pretty shrub with elegant foliage and showy, purple flowers, here everblooming.

*POLYGALA SPECIOSA, South Africa ....

Flowers large, purple, showy.

*POLYGALA VIRGATA, South Africa ... ...

Leave's narrow; long racemes of light purple flowers.

*POLYGONUM ELEGANS, Southern Italy... .

Dwarf; wiry stems covered with myriads of small

white tlowers; very effective for rockeries, as also for b ouquets.

Polygonum lanigerum, India and Australia....

Very remarkable for its white woolly foliage and copper colored inflorescences.

*POTERIUM SPINOSUM, Greece...........

Peculiar looking little shrub with minute leaves, flowers and berries, all tinted of different shades of green and red.

*PROSTANTHERA NIVEA, Australia........

A small shrub, with minute leaves and snow white flowers.

Raphiolepis japonica, Japan..............

Dwarf, compact growing; leaves coriaceous dark green; pretty, white fragrant flowers in umbels; berries black, shining. 
*Reinwardtia tetragyna, India... ......... \$

*Reinwardtia trigyna, India................

The correct names for Linum tetragynum and L. trigynum, both much admired pretty little plants, covered all the year round with golùen yellow flowers, similarin shape to the common flax, but larger.

*PHODORHIZA FLORIDA, Teneriffe....... slender growing; gracefully beuding stems bearing long panicies of pinkish white convolvulus like ilowers; wood and roots being highly rose scented.

RIBES FASCICULATUM SINENSE, China...

Ribes speciosum, California..............

Stems covered with dense reddish prickles; elegant foliage; flowers blood red, fuchsia like, hanging down all along the stems; one of the prettiest among winter flowering shrubs.

Robinia hispida, Eastern United States........

Stems and branches bristly; flowers large in long racemes similar to those of the common "locust tree" but of deep rose color.

*Rogiera cordata. Mexico ..................

Foliage dark green; pretty rose flowers, in terminal heads.

Rosmarinus officinalis, Southern Europe .......

Common "Rosemary"; a popular favorite for its aromatic leaves, pretty light blue fluwers, much sought for by bees; well suited for hedges, will thrive in rocky and dry places, endure some cold and salt winds from the sea.

"ROYENA LUCIDA, south Africa...........

Tall yrowing, with handsome shining foliage; flow ers white.

*RUBIACEA, species, Southern Mexico ... . .

Vigorous and comp:tet growing, with shining round coriaceous leaves; flower pure white. sweet scented. said to be very showy.

*RULINGIA PANNOSA, Australia ..........

Very pretty and curious with the fleecy coating of its leaves.

Salvia coccinea, Mexico ................ flowess, blooming literally all the year round. 
*Salvia farinacea, Mexico ................\$

Stems meals white; very pretty, blue flowers in long spikes.

*Salvia Heerii, Mexico

Tall growing; flowers scarlet, very showy, almost all the year.

*Salvia leucantha, Mexico

Stem and leaves glaucous; calyx of flowers covered with dense violet wool.

*SALVIA SESSEI, South Mexico and Guate-

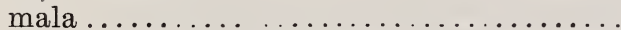

Arborescent; with aromatic bright green foliage and very conspicuous vermilion orange flowers, in large terminal spikes; late bloomer; a most remarkable plant.

*Salvia splendens, Mexico............... One of the most popular garden plants, everblooming in Southern California.

*SCHOTIA LATIFOLIA, South Africa....... Rich ornamental foliage, of reddish color when young; flesh colored flowers in large panicles.

*SCHOTIA SPECIOSA, South Africa. . . . . . .

Leaves more finely cut; flowers crimson.

*SECURINEGA LEUCOPYRA, India .......

A spiny shrub, with sweet white berries, suitable for hedges.

SEDUM SPATHULATUM, California.......

A giant among Sedums or "stonecrops," growing several feet high; leaves fleshy, cylindrical, bright green; tall panicles of golden yellow star-like flowers: one of the most striking plants in our gardens during the winter time.

Solanum aviculare, New Zealand.

Leaves large, deeply cut; flowers blue; berries oval, orange red.

*Solanum indicum, India

Arborescent; leaves acanthus shaped; flowers white;

50

berries round, yellow.

Solanum marginatum, Abyssinia ............

Prickly, covered all over with white tomentum; flowers purple and white; bcrry large, apple shaped. yellow. 
*SOLANUM PIERREANUM, South America..\$

Very interesting and pretty for its fruits striped different colors.

*Solanum pyracanthum, Madagascar ..... ...

Stems and leaves armed with fiery spines; flowers blıish. All above Solanums are quick growers. most suitable for immediate and picturesque effect, and not very particular about soil.

*Sparmannia africana, South Africa... .....

Making a handsome foliage plant; but not less valuable for its pretty white flowers produced in winter.

*SPARMANNIA PALMATA, South Africa... Smaller, finely cut leaves; flowers white.

Spartium junceum, South Ėurope............. The so-called "Spanish broom"; quite at home on this coast, where its bright yellow, fragrant blossoms can be picked every day in the year. Stands drought well and many degrees of cold.

Spiræa prunifolia flore pleno, China and Japan. .

Spiræa cantoniensis, China..............

Both well known and popular shrubs; first with double flowers; second bearing the name of "bridal wreath"; here almost evergreen and everblooming.

*Streptosolen Jamesoni, Ecuador . . . . . . . . . . . .

Known also as Browallia Jamesoni; to be sure one of the handsomest and most striking blooming shrubs, attaining quite a large size, with myriads of yellow and orange flowers, produced for many months ic the year. Will do best in open suuny places, and with liberal treatment.

* Swainsona galegaefolia, Australia .. . . . . .

*Swainsona galegaefolia alba, Australia...

First with purple. second with pure white, pea shaped flowers in bunches: this last having become very popular of late as a florist flower

*TAGETES LACERA, Lower California...... shrubby "marigold" with metallic green, finely cut foliage, and a profusion of pretty yellow flowers.

TAMARIX KASHGARICA, Turkestan.......

Fine bluish foliage; flowers in long panicles colored intense pink; blooming in the fall; a most desirable novelty, also, for the Eastern States, being sure to stand a great deal of cold. 
Tamarix plumosa, Japan $\ldots \ldots \ldots \$$

Foliage not less feathery than the preceding, but of a deeper green color; all covered in spring with spikes of very pretty rose color.

*Tecoma capensis, South Africa.............

Very popular here and mostly grown as a standard, although its long, flexible branches may well classify it among climbers. Evergreen here, bearing its orange scarlet flowers almost without interruption

*Tecoma Smithii, garden hybrid............ Obtained a few years ago in Adelaide, South Australia, by crossing the precediug with $T$. velutina, considered to be a mere variety of the following.

*Tecoma stans, Southern Texas and Northern Mexico ....................... "Palo de arco," shrubby, not a climber, a magnificent bloomer; flowers golden yellow, trumpet shaped, delightfully fragrant.

*TEMPLETONIA RETUSA, Australia

A tall shrub or small tree; pretty, dark green foliage; showy, brick colored, pea shaped flowers.

*Thevetia neriifolia, West Indies............ Compact growing; leaves shining as if varnished; Howers of a beautiful canary yellow; very fragrant, called by some "the yellow Oleander."

*Thevetia nitida, West Indies.............. Similar to the above; leaves darker green; flowers buff yellow.

TEUCRIUM BICOLOR, Chile .... . . . ..

Dwarf growing; flowers white and blue; very pretty.

Teucrium fruticans, Southern Europe .

More vigorous and taller growing; leaves silvery white underneath; flowers light biue, nearly all the year; a capital plant for dry places.

*TRICHOSTEMA LANATUM, Southern California................ .. Called "Romero" by the natives, who think very highly of its aromatic aud medicinal properties. In habit looking somewhat like the classical Rosemary; Howers red and blue; very showy.

*TURPINIA ARGUTA, Southern China......

Leaves large, glossy; flowers purplish white. 
Ulex europaeus, Europe $\ldots . . \ldots \ldots \ldots \ldots \$$

The well known "gorse" or "furze," doing very well on this coast, its yellow flowers appearing in almost every month of the rear

Umbellularia Californica, California.... ......

In favorable conditions attaining size of a tree; foliage strongly aromatic; "bay" and "laurel" of the natires.

Veronica, garden varieties, of which we can supply the best.................... All doing aximirably well along our cosst, and everblooming; nothing better for planting in exposeả places by the sea.

Viburnum opulus sterilis, Europe........... The old fashioned "snow ball," doing very well here.

Viburnum tinus, Southern Europe .......... The well known "laurus tiuus," quite a favorite here and everblooming.

*VIGUIERA TOMENTOSA, Lower California. Tall and bushr; leaves silvery woolly; flowers yellow, in ample corymbs, similar to small single sunflowers; here blooming winter and summer. A striking plant altogether.

*VIMINARIA DENUDATA, Australia.......

Quite remarkable, long wiry branches, with leaves reduced to very long petioles, and crange jellow flowers in terminal racemes.

*VISNEA MOCANERA, Teneriffe .......... Glossy camellia-like foliage; small waxy fragrant flowers; berries edible.

*WESTRINGIA ROSMARINIFORMIS, Australia $\ldots \ldots \ldots \ldots \ldots \ldots \ldots \ldots \ldots \ldots$

Low growing and blooming quite small; pretty, pure white flowers.

*Wigandia imperialis, Mexico.............

*Wigandia macrophylla, Caracas............

Both highly decorative and striking plants, with very large leaves and showy panicles of bluish flowers.

Xanthoceras sorbifolia, Manchuria...........

Pretty divided foliage; flowers large, white with crim son blotches, in early spring. 


\section{TABLE A.}

TREES AND SHRUBS that will stand severe drought, practically without irrigation, even where the annual rainfall will not exceed 8 or 10 inches, most of them standing, however, only a few degrees of frost.

Acacia ............ 33, 49

Atriplex Brewerii...... 50

Casuarina ........... 36

Callistemon, all species .. 53

Cedrus atlantica Calycotome villosa...... 54

Cupressus Guadalupensis. 37 Cassia artemisioides .... 54

Cupressus sempervirens.. 38 Cassia tomentosa:....... 54

Eucalyptus Globulus..... t0 Chilopsis saligna........

Eucalyptus Rameliana... 40 Cistus, all species.... ... うう

Eucalyptus rudis.......40 Euphorbia splendens..... 60

Grevillea robusta ... . . 42 Genista monosperma .... 61

Parkinsonia aculeata... 44 Hakea, all species ..... 62

Parkinsonia Torreyana.. 44 Halimodendron argenteum 62

Pinus Halepensis...... t5 Lantana, all species ... . 65

Pinus Pinea.... ...... t5 Lavandula, all species.... 65

Schinus molle ........ 47 Leptospermum, all species 66

Schinus terebinthifolius.. 47 Medicago arborea $\cdots . \ldots 67$

Melaleuca, all species. ... 67

Melianthus, all species.... 68

Myoporum, all species....6 68

Phlomis fruticosa ....... 69

Pittosporum phylliraeoides 70

Tamarix, all species... $74-75$

Viminaria denudata... . . 76 


\section{TABLE B.}

Trees Best Suitable For Avenue and Street Planting

\section{First Size.}

PAGE PAGE

Acacia dealbata........33 Fraxinus velutina ...... 42

Acacia decurrens....... 33 Grevillea robusta ...... 42

Acacia elata......... 33 Juglans nigra. ........ 4.

Acacia melanoxylon .... 33 Juniperus phoenicea. . . 42

Aleurites moluccana.. ... 35 Libocedrus decurrens.... 43

Araucaria excelsa ....... 35 Liriodendron tulipifera. . 43

Araucaria Bidwillii .... 33 Machaerium tipa .. $\ldots 44$

Arbutus Menziesii...... 35 Magnolia grandiflora ... 44

Catalpa speciosa ....... 36 Maytenus boaria. ...... 44

Cedrela serrata. ....... 36 Melia azederach $\ldots \ldots . .44$

Cedrela sinensis ....... 36 Paulownia imperialis .... t5

Celtis sinensis ....... . 37 Persea indica. ......... to

Chamaecyparis Lawsoni. . 37 Phoenix Canariensis .. . j

Cupressus, all species ... 37 Phoenix dactylifera $\ldots . .6$

Enterolobium cyclocarpum 39 Pinus, all species...... 45

Eucalyptus botryoides ... 39 Piptadenia cebil........ 45

Eucalyptus citriodora.... 39 Pircunia dioica ..... 46

Eucalyptus corynocalix... 38 Populus pyramidalis .... 46

Eucalyptus robusta...... 40 Populus Caroliniana..... 46

Eugenia myrtifolia..... 25 Salisburia adiantifolia ... 47

Ficus Bengalensis...... 40 Salix babylonica. ......47

Ficus Cunninghamii ... 41 Schinus molle... ..... 47

Ficus glomerata........41 Schinus terebinthifolius.. 47

Ficus infectoria.......41 Sequoia gigantea.......4 4

Ficus macrophylla...... 41 Sequoia sempervirens.... 47

Ficus religiosa ....... 41 Sterculia, all species...47-48

Ficus retusa.........4 41 Tristania conferta......48

Ficus rubiginosa........ 41 Washingtonia filifera... $z$ 


\section{Second Size.}

PAGE

PAGE

Callistemon speciosus. ... 53 Hymenosporum flavum... 64

Calodendron capense .... 35 Ilex latifolia. . . . ..... 42

Carumbium populifolium. 3i Jacaranda mimosaefolia. . 42

Chamaerops humilis .... 3 Lagerstruemia indica ... 65

Cinnamomum camphora.. 37 Lagunaria Patersoni .... 65

. glanduliferum 37 Laurus nobilis......... 65

" pedunculatum 37 Livistona australis ......

Cocos datil .... ..... 3 Lyonothamnus floribundus 43

Cocos flexuosa ........ 3 Nerium oleander ... ... 69

Cocos plumosa.... $\quad \ldots .63$ Phoenix reclinata ... . . 6

$\begin{array}{llllll}\text { Corynocarpus laevigata. . } & 3 i & \text { Phoenix rupicola... } & \ldots & \ldots & 6\end{array}$

Eucalyptus calophylla.... 39 Pittosporum rhombifolium 46

Eucalyptus ficifolia ... . 39 Pittosporum undulatum. . 46

Eucalyptus rudis ...... t0 Serenoa arborescens .... 7

Erythea armata....... + Tecoma stans. ..... . 75

Erythea edulis . ...... + Trachycarpus excelsus... $i$

Genista æthnensis .....61 Washingtonia Sonoræ ... †

Hibiscus rosa sinensis.... 63

N. B. Summary description, degree of hardiness and size of each of the above are given at the pages named.

\section{CLIMBING and TAILING PLANTS}

These are general favorites in our country, on account of their beauty being constantly under our eyes, and also because we cannot refrain from considering them as an integral part of our homes. Of many it is quite true that man can enjoy them better under such domesticated conditions, than in their native habitats, where impelling struggle for life pushes them up to the top of the loftiest trees, there offering gorgeous displays of coloring, enjoyable only by creatures provided with wings. No wonder. therefore. that 
the number of such plants gathered in our gardens from every country, is already large, and we feel bound to pay special attention to increase it more and more with valuable additions. Climbers or "Vines," as they are commonly called, are generally fast growers, and with few exceptions, will need plenty of nourishment and water. Among them some will be more suited to adorn verandahs and houses, while others will show better if let to run at random on large trees; some will be the right thing for covering walls and fences, or for concealing unsightly buildings; some will find best employment among rocks or on sloping ground. In every case a judicious selection is recommendable in order to attain a succession of bloom and to avoid offensive association of colors. In the list that follows, the predominant color of each kind is carefully given, and season of blooming when possible.

*Abrus precatorius. India $\ldots \ldots \ldots \ldots \ldots \ldots \ldots$

Flowers small, yellowish, pea shaped; seeds scarlet, shining with black eye, used for necklaces, rosaries, ete.

*Adhatoda cydoniaefolia, Brazil ............

Leaves ovate, deep green; flowers rich purple and white.

*Agdestis clematidea, Mexico...............

Light green roundish leaves; white star-shaped flowers, looking like some clematis.

Akebia quinata, Japan.................

Leaves in fives; flowers dark purple. fragrant; quite a free grower,

Akebia quinata, fl. roseo, Japan............ .

A pretty variety of the ahove with rose colored flow. ers.

**Allamanda cathartica, Guiana............

Flowers funnel shaped, large, bright yeilow.

*ALOE CILIARIS, South Africa ...........

Stems slender; leaves gay greeu, ciliated at their base; flowers very profuse, bright scarlet, keeping long when cut. Grown on the Riviera for export of rut flowers during winter. 
Ampelopsis quinquefolia, Southern Atlantic Staces ....................\$

The well known Virginia creeper; fast grower and admirable for the rich red color assumed by the leaves before they fall down.

Ampelopsis tricuspidata, Japan. . ............

curiously known in this country as "Boston ivy"; a great grower: here displaying the richest hues of copper and bronze color during summer; deciduous from November to March.

*Antigonon leptopus, Mexico...... .........

Called "Rosa de Montana" and "San Miguelito"; with deciduous stems, one of the prettiest climbers known, for the mass of bright pink flowers it displays during the summer. Prefers sunny and very hot places.

*ARGYREIA CUNEATA, India...........

Foliage shiny, silky underneath; flowers large, shape of Ipomaea. deep bright purple.

* Aristolochia elegans, Brazil ..............

A truly elegant plant, for its pretty foliage and curiously mottled flowers, free from any bad smell that make other Aristolochias rather objectionable.

*ARISTOLOCHIA GIBERTI, Paraguay...... There called "patito," that is, small cove, from the strange appearance of its flowers.

**ARISTOLOCHIA TAGALA, Philippine Is-

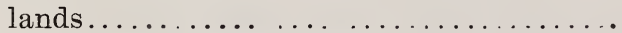

*Artabotrys odoratissima, Java.............

Leaves glossy, dark green; flowers reddish brown, powerfully scented, the celebrated "ylang-ylang" being extracted from them.

*Asparagus comorensis, Comore Islands....... Darker green and more vigorous growing than A. plumosus nanus, to which it is very near.

*ASPARAgUS DECUMBENS. South Africa. .

Very fine, and drooping down in long festoons of a light bluish color. Capital for hauging baskets.

*Asparagus plumosus, South Africa.

So much grown under glass and for florists' üse; here doing splendidly out of doors.

*ASPARAGUS SCANDENS DEFLEXUS, South Africa.....

Somewhat resembling the following, but much finer 50 to 100 and more graceful. 
*Asparagus Sprengeri, South Africa....... \$ 25 to 100 Very pretty, shining foliage and minute white flowers; invaluable for hanging baskets.

*BAUHINIA VAHLI, India.............. .

An immense vine with very large bilobed leaves. beautifully colored when young; flowers dark purple, not showy.

**Beaumontia grandiflora, India

Foliage large, glossy; flowers white, larger than Mandevilla, very fragrant.

*BIGNONIA AEQUINOCTIALIS, Brazil..... Very vignrous; flowers light yellow, in bunches.

*Bignonia argyreo violascens, South America... Young leaves beautifully veined with white, bright violet underneath; flowers purple.

*Bignonia Chamberlayni, Brazil. ............ Shining foliage; flowers creamy white.

*BIGNONIA LINDLEYI, Mexico........... Long panicles of purple flowers, blooming quite young.

*Bignonia magnifica, Columbia . ...........

Rich foliage; panicles of very jarge flowers, mauve to crimson, with yellow throat; a truly magnificent species.

Bignonia speciosa, River Plate............

Leaves ovate, shining; flowers large, delicate mauve. finely reined deep purple.

Bignonia Tweediana, River Plate..... . . . . .

A great grower, clinging to rocks and walls; leaves minute, light green; covered with large goldeu flowels in spring. This and the preceding will stand some frost.

*Bignonia venusta, Brazil

One of the most desirable climbers we have in our gardens; covering roufs, ar.bors, etc., with a sheet of the richest orange from September to Anril. Other kinds see under Pithecoctenium and Tecoma.

*BIGNONIA Species, Paraguay............

Very distinct palmate glossy foliage; very long bunches of yellow flowers.

*Bougainvillea glabra, Brazil ........... 25 to 100

*Bougainvillea lateritia, Brazil........... 50 to 200 
*Bougainvillea Sanderiana, Brazil. . ....... . 50 to 100 *Bougainvillea spectabilis, Brazil ............ 25 to 100

Deservedy considered among the showiest blooming climbers, Bougainvilleas will ihrive better in sunny, warm places, with plenty of room for roots and for the shoots to run over; second named has flowers of a dull brick color, very pleasant, the others of differeut shades of mageuta color, being a mass of bioum almost all the year rousd.

Boussingaultia baselloides, Peru............. The popular "iIadeira vine"; tuberous rooted stems, deciduous; leaves fleshy; bunches of minute, whitish scented flowers in the fall.

*BUdDLEyA MADAGaSCARIENSIS, Mada-

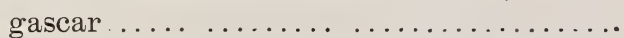
Most vigorous grower, large leaves, shining above, white underneath; long trusses of yellow flowers produced all through the winter.

*CANARINA CAMPANULA, Canary Islands. . Mentioned already at page 22 ; pretty, red and orange flowers.

*Capparis spinosa, Southern Europe.... ...... Mentioned under economic plants; well worth growiug ouly for its flowers.

*CARDIOSPERMUM HIRSUTUM, India . ... Finely cut fuliage; feathery white flowers.

*Cereus Macdonaldiae, Honduras .........

A cactus with sleuder, loug, trailıug stems and immense flowers, while aud yellow buff color, vanilla scented, aud opening at night duriug summer.

* Chlorocodon Whitei, South Africa.... ....... Leaves large cordate; flowers very curiously shaped, white and maroon color.

**Cissus discolor, India ................. To be sure oue of the most beautiful variegated plants, rivalling with the choicest Rex Begonias. Will need the warmest locations. but partial shade.

*Cissus incisa, Southern Texas and Mexico.... . A rank grower with fleshy leaves, suitable for rockeries.

*Cissus rhombifolius, Trinidad .............

V1gorous growing; rich, glossy, trifoliate foliage. 
CLEMATIS CAMPANIFLORA, Portugal......\$

Pretty, bell-shaped, light blue flowers in spring.

*CLEMATIS CRASSIFOLIA, Hong Kong.... .

Remarkable elegant foliage, generally variegated grẹish white; flowers white, in summer.

Clematis coccinea, Texas. . .............

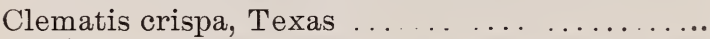

Both very fine growers and almost everblooming; flowers fleshy, nearly globular, scarlet in the first, violet in the second; will stand much frost.

CLEMATIS DRUMMONDI, Southern $\mathrm{T}$ e $\mathrm{x}$ a $\mathrm{s}$

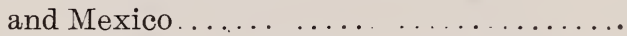

A vigorous grower too, with white flowers; seeds with plumose tails four inches long.

*CLEMATIS MEYENIANA, Hong Kong. . . . . . Very vigorous; flowers white.

CLEMATIS MONTANA GRANDIFLORA, Himalaya . . . . . . . . . . . .

Unrivaled for its gorgeous display of white, starshaped flowers in early spring; very hardy.

Clematis paniculata, Japan..............

A great grower and a great bloomer: white flowers in long panicles; will stand many degrees oi frost.

Clematis, garden varieties. . . . . . . . . . . .

All leading varieties supplied on short notice. Clematis as a rule do well if in deep soil; grafted plants ought to be preferably worked on our vigorous native kinds.

**Clerodendron Balfouri, tropical Africa ......

Flowers white and scarlet; one of the most admired climbers, suitable also for pot culture.

**CLERODENDRON KEMPFERII, China.... Flowers of the brightest scarlet.

Cobaea scandens, Mexico................

Fast grower and well known, recommendable wherever immediate effect is desired.

CONVOLVULUS CANTABRICUS, Southern

Europe......................

Trailing, white silvery foliage; beautiful bright rose flowers opening well in the sun.

*CONVOLVULUS HERMANNIAE, Peru..... . Quite distinct, with narrow leaves; small, pretty rose flowers. 
CONVOLVULUS MACROSTEGIUS, S o $\mathrm{ut} \mathrm{h}$

California Islands................\$

An exceedingly vigorous trailing plant. with woody stems; leaves dark green; flowers large, cream white, sometimes flashed with pink, five of them on each peduncle in succession; an admirable plant for large rockeries.

Convolvulus mauritanicus, North Africa.......

Compact growing; pretty blue flowers produced in the greatest profusion, suitable also for hanging baskets.

CONVOLVULUS TENUISSIMUS, Southern

Europe....................... .

Spreading over the ground, silvery white foliage; flowers large, of the brightest rose color.

CONVOLVULUS VILLOSUS, California ....

Hardly trailing; stems and leaves appearing whitish from the iur they are covered with; flowers cream color; a very pretty border plant.

*CORYNOSTYLIS AUBLETII, Guiana. ....

Very vigorous; flowers white, in shape like a magnified violet.

*CRYPTOSTEGIA GRANDIFLORA, Mada-

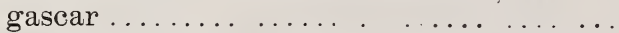

Very vigorous, with large ovate fleshy leaves, and showy trumpet-shaped pink flowers. Yields also rubber of good quality.

*DIOCLEA GLYCINOIDES. River Plate... .

100

An exquisite climber of moderate growth; leaves trifoliate, shining; large pea-shaped flower's in bunches like the common Wistaria, of beautiful scarlet color.

*Dioscorea sativa, India . . . . . . . . . . .

One of the cultivated "yams" or "sweet potatoes," producing small tubers in the axil of the leaves. Very pretty foliage.

*DISEMMA COCCINEA, Australia .......... Allied to the Passion Vines. Finely cut, elegant foliage; flowers brick red.

*Dolichos lignosus, India................

Wrongly known in this country as "Australian pea"; a very rapid grower, bearing an immense number of pretty, pea-shaped, purple flowers, mostly in winter.

*Eccremocarpus scaber, Chile..............

Pretty, light green foliage; orange tubular flowers in panicles; will show best trailing over shrubs. 
*FAGELIA BITUMinOSA, South Africa.....\$

Fast grower, but of muderate size; leaves covered with clammy hairs; fluwers pea-shaped. yellow, tipped with violet.

Ficus stipulata, China and Japan ............

Quite remarkable, attaching itself to walls, rocks, hoards, and even glass; haviug smaller leaves on its barren stems, much larger on those bearing fruits, which are woody aud not eatable.

Fragaria indica, India....... ..........

A strawberry, with golden yellow flowers and red, showy, but tasteiess fruits, excellent for hauging baskets.

Fuchsia procumbens, New Zealand . . ......... small ruundish leaves; curious red and yellow flowers, followed by purple berries; very pretty for hanging baskets.

Gelsemium sempervirens, from Virginia south-

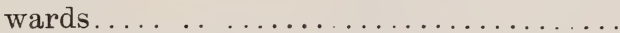

Gelsemium sempervirens flore pleno..........

The "Virginia" or "Caroliue Jessamine," single and double flowers, bright yeliow, deiliciously fragraut.

*GLORIOSA VIRESCENS, Natal...........

rerenuial trom a bulbous root; llowers very pretty red and yellow.

Hedera helix chrysophylla, Southern Europe... A variety of the common ivy, with golden berries.

HOLBOELLIA LATIFOLIA, China ......... Beautiful coriaceous foliage; fluwers purple, very fragrant; iruit large, edible.

*Hoya carnosa, South China and Queensland.... 'The old fashioned "wax plant"; flowers light pink deliciously scented, everblouming here.

*IPOMAEA AUREA, Lower California....... Root tuberous; woody, slender stems; small trifoliate leaves tinged intense red when young; flowers bright lemon yellow, over two inches across, opening flat; a splendid species.

* IPOMAEA CHRYSANTHA, West Africa... Rich glossy foliage; golden yellow flowers, said to be very large and very fragrant.

* IPOMAEA DISSECTA, India............

Very fine, pretty foliage; flowers purple. 
*Ipomaea grandiflora, India..............\$

Flowers very large, with long tube, white, opening at night.

**Ipomaea Horsfalliae, West Indies

To be sure one of the finest; flowers in large bunches, beautiful rose color; a favorite in European hot houses

*Ipomaea Learii, Ceylon. … . . . . . . .

Flnwers intense blue when opening, ehanging to purple; day bloomer; one of the most popular kinds.

*Ipomaea Mexicana, Mexico.... . . .......

Flowers purple with crimson center, deciduous.

Ipomaea pandurata, Southern Atlantic States...

Root tuberous, attaining very large size; an immense grower, and profuse blonmer; flowers in clusters, pinkish purple.

*Ipomaea purpurea flore pleno, Mexico... . . . . . A very pretty and curious morning glory, with semidouble flowers, white. striped purplish blue.

*IPOMAEA SELLOWII, Brazil

Woody; leaves cordate, woolly; flowers large, of a very pleasant rosy shade.

*IPOMAEA species, Cuba

Exceedingly vigorous; foliage coriaceous and shiny. laking in winter very pretty bronzy hues; has not yet bloomed here.

*Jasminum azoricum, Madeira

*Jasminum gracillimum, Borneo ...... . . . . .

25

*Jasminum grandiflorum, India .... . . . . . .

JASMINUM HUMILE, India................................

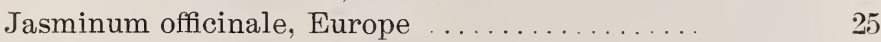

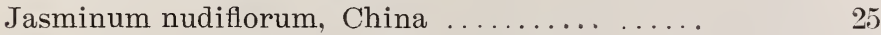

Jasminum revolutum, Himalaya. . . . . . . . . . . . . . 25

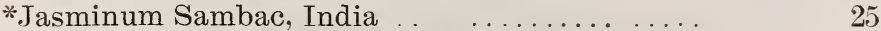

*JASMINUM SIMPLICIFOLIUM, Australia... 25

*Jasminum undulatum, China.............

The weil known and popular Jasmines, to be sure among the best climbers; all white flowered, except J. humile, J. nudiflorum and J. revolutum, which have rellow flowers.

*KENNEDYA NIGRICANS, Australia.

Exceedingly vigorous; flowers deep violet and yellow. 
*KENNEDYA RUBICUNDA, Australia........\$

Flowers large, deep scariet.

Lapageria rosea, Chile .................

One of the noblest and choicest climbers, belouging to the same order as the lily; flowers bright crimson; doeswell right on the corst, but will prefer shady places where the atmosphere will never become too dry.

Lapageria rosea var. alba, Chile....$\ldots \ldots \ldots$

$A$ white flowered variety of the preceding; very choice.

LARDIZABALA BITERNATA, Chile........

Large, dark green, glossy leaves; flowers purple and white, in bunches.

Lathyrus splendens, Southern California ..... Well named the "pride of California"; lnoking somewhat like a sweet-pea, but perenuial; flowers large, of the brightest crimson, produced all winter; will look at its best if allowed to run on large bushes.

Linaria cymbalaria, Europe ............. The so-called "Kenilworth Ivy"; foliage minute, bright green; rery pretty white and lilac flowers. Capital for hanging baskets.

LONICERA CAPRIFOLIUM, Europe.... .....

The typical "honeysickle." having large white and yellow flowers, the most fragrast among its congeners: deciduous.

Lonicera fuchsioides, garden origin? ........

Almost everblooming; flowers bright red, scentless.

LONICERA IMPLEXA, Italy . . . . . . . . . . .

Compact growing, evergreen and everblooming, flowers rosy white; will thrive on cliffs overhanging the sea.

*LONICERA LONGIFLORA, Southern China. . Finwers white changing to yellow, several inches long.

*LOTUS CANARIENSIS FLORIBUNDUS, Canary Islands.

*Lotus peliorynchus. Canary Islands

Both of them trailing, and well adapted for rockeries. and belter still for hanging baskets; first having yellow, second scarlet flowers.

LYCIUM CHILENSE. Chile . . . . . . . . . .

Leaves looking like frosted; small purplish flowers. 
*LYCIUM HORRIDUM, South Africa .......\$

Larger in all its parts than other species mentiored, like them standing well drought and rough treatment.

* LYCIUM RICHI, Lower California..... . . . .

An extensive trailer with minute bright green leaves, purple flowers, and shining scarlet berries.

* Mahernia glabrata, Cape of Good Hope.......

Trailing, covered with myriads of bell shaped, bright yellow flowers, exhaling exquisite perfume; very desirable also as a pot plant.

Mandevilla suaveolens, Chile .............. Deciduous, beautiful foliage; large, white, funnelshaped flowers; very fragrant.

* Manettia bicolor, Brazil................

* Manettia cordifolia, Brazil ..............

Both very elegant climbers, of moderate growth; flowers tubular, scarlet and yellow in the first, pure scarlet in the second.

Maurandia erubescens, Mexico............. Known also as Lophospermum; woolly all over; flowers large, rosy purple.

Maurandia semperflorens, Mexico ........... More slender; flowers smaller, lavender colur, or white.

*MORRENIA ODORATA, Paraguay........ A noble vine; foliage very distinct; flowers white, very fragrant.

Muhlembeckia complexa, New Zealand .......

A very curious looking plant. forming a dense matting of black wiry stems with small round, fleshy leaves, and minute, waxy, white flowers, much a fa. vorite with bees.

Myrsiphyllum asparagoides, South Africa .....

The correct uame for the so-called "smilax," so extensively used for florists' use, here doing finely in the open.

*OXERA PULChELLA, New Caledonia . ... .

A handsome climber; flowers large, yellowish white.

*P ASSIFLORA ALBA, Brazil............

Light green foliage; flowers pure white.

Passiflora coerulea, South America........... Flowers white, purple and blue; fruit small, orange color. 
Passiflora edulis, Brazil.................\$

Flowers white and purple; fruit egg-shaped, deep violet, full of pleasant acid pulp.

**PASSIFLORA LAURIFOLIA, West Indies. .

Flowers red and violet, fragrant; fruit large, brownish yellow. much prized.

*Passiflora Pfordii, garden origin ?..........

Growing not so thick; leaves leathery, not attacked by caterpillars; flowers large, mauve and white, very fragrant.

*Passiflora manicata, Peru ...............

Flowers vermilion scarlet, exceedingly showy.

**Passiflora quadrangularis, tropical America. .

Leaves large, broadly ovate; flowers very large, blue, crimson and purple, very fragrast; fruit edible, several pounds in.weight.

*Passiflora racemosa, Brazil...

Flowers deep red in terminal racemes, quite distinct.

*Passiflora violacea, Brazil................

Almost everblooming here; flowers large, of different shares of violet color.

All above "Passion flowers" rank among the most free growing climbers, their vigour, as seen here, being really wonderful, and the beauty of their flowers being unsurpassed.

Pelargonium peltatum, South Africa.... . . ...

The so-called "ivy-leaved Geraniums," so much improved of late years; flowers single and double, ranging from pure white, through different shades of pink and red, to bright scarlet. To be sure one of the most useful plants for southern gardens. For large quantities prices quoted on application.

PENSTEMON CORDIFOLIUS, Southern California ........................

Woudy, scrambling over bushes; flowers of a beautiful scarlet.

*Pereskia aculeata, West Indies...........

Commonly called "Barbadoes gooseberry," from the fruit being edible; a sort of cactus with trailing stems, true dark green leaves, and small whitish flowers; excellent for rockeries. 
Periploca graeca, Southern Europe. .........\$

*Phaseolus caracolla, Peru...............

"Caracol" and "suail vine" from the curious yppearance of its fleshy, light purple and sellowish flowers, exceedingly fragrant.

*PHASEOLUS TRUXILLENSIS ? S o u t h e r $\mathrm{n}$

Mexico.

Very vigorous and floriferous; fuliage similar to the preceding; flowers very large. light blue, shading to bronze color, delicately fragrant.

Physianthus albens, South Brazil ...........

This has been ealled the "cruel vine" for its whitish flowers entrapping moths and butterflies; a very vig. orous grower.

*Physianthus graveolens, Brazil............

Known also as Schubertia grandiflora; stems and leaves pubesceut; flowers large, white, fragrant.

*Pilogyne suavis, Cape of Good Hope..........

An exceedingly quick grower; pretty, minute foliage; numberless tiny, greenish white flowers, very frag. rant. Capital for covering fences, etc.

*PITHECOCTENIUM BUCCINATORIUM, Mexico......................

The correct name for Bignonia cherere; very vigorous and clinging like Bignonia Tweediana; foliage ample, shining; flowers red orange with yellow throat, very showy.

PITHECOCTENIUM CLEMATIDEUM, River

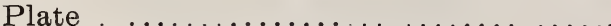

PITHECOCTENIUM MURICATUM, Mexico. .

Both vigorous growing. Bignonialike climbers; flowers large, somewhat woolly, pure white and fragrant in firs:, yellow and white in the second.

PIPER FUTOKADSURA, Japan............ Closely related to the true black pepper of commerce, hut much hardier; fleshy, roundish leaves; berries bright red.

*Plumbago capensis, South Africa...........

*Plumbago capensis alba, South Africa. ...... 
*Plumbago rosea, India ................ \$

First well kuown and one of the most prominent climbers, much prized for its profuse sky blue flowers; second being a pure white variety of the same; third has splendid rose-colored flowers, and will require more heat than the above.

Polygonum multiflorum, China............

Rank growing; flowers minute white, in large bunches, ver: fragrant.

Pueraria Thunbergiana, Japan .... ........

An immense grower with exceedingly large trifoliolate leares; flowers pea-shaped. dark violet.

*Rhoeo discolor, South America ... . . . . . . . .

More generally known as Tradescantia discolor; also by the strauge and popular name of "Wandering Jew"; invaluable for hanging baskets; also for growing in odd corners, thriving even in the dark.

*RHYNCHOSIA MINIMA, West Indies....... Very dense and fast growing, rapidly covering a great surface: flowers small, yellow streaked red.

ROSA BANKSIAE, single white, China....... Exquisite small white flowers in early spring, exhaling a most delicate perfume.

ROSA BANKSIAE SEMPERFLORENS, double yellow, China .... ..........

A sport originated in Santa Barbara, blooming pro. fusely all the year round, and very fragrant.

*Rosa gigantea, Burmah ...............

Truly a giant among Roses; exceedingly vigorous; flowers large, white.

Rosa moschata, Himalaya... .............

Quite vigorous; single white flowers in long panicles; one of the kinds used for distilling "attar" of roses.

Rosa sinica, China, nacuralized in Florida.......

The so-ralled cherokee Rose, so popularin (Yalifornia. where it blonms most of the year.

*RULINGIA PARVIFLORA, Australia ......

Trailing over the grouud; very peculiar and pretty foliage; myriads of small pink fluwers in spring.

*Russelia juncea, Mexico

Stems rush-like, bright green, covered all through the year with searlet tubular flowers; first rate plant for rock work and for hanging baskets. 
*SALPICHROMA RHOMBOIDEA, Paraguay..\$

Mentioned already under economic plants; worth growing also for its pretty, bell-shaped, white flowers and transparent white berries.

*SEMELE ANDROGYNA, Teneriffe

Looking like a gigautic "smilax" will climb 50 or 60 feet, displaying dark green tropical foliage, likely to be mistaken for some of the Indian climbing Palms.

*Senecio macroglossus, South Africa... . . . . . .

Similar to the following in the leaves, which are of darker green; flowers star-shaped, yellowish.

*Senecio mikanioides, Southern Africa . .....

Curiously known as German Ivy; leaves fleshy, shaped like ivy; literally covered with tassels of yellow flowers during winter.

Smilax aspera, Southern Europe .... . . . . . .

Very vigorous and very prickly; leathery foliage, generally spotted white; small fragrant white flowers in long bunches, followed by shining red berries.

**SOLANDRA GRANDIFLORA, Jamaica......

Large white, trumpet-shaped flowers, resembling Daturas; a truly striking plant.

* Solandra laevis, South America .... . . . . . .

Not less vigorous than the preceding; flowers with a long narrow tube, light yellow.

Solanum jasminoides grandiflorum, South Amer-

ica $\ldots \ldots \ldots \ldots \ldots \ldots \ldots \ldots . \ldots \ldots \ldots$

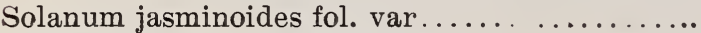

Both rapid growers and very free bloomers: flowers white in umbels; at some distance looking like Jasmines.

*Solanum Seaforthianum, West Indies.... ....

Somewhat similar in habit to the above, but having blue flowers and red berries.

*Solanum Wendlandi, Guatemala. ...........

To be sure one of the most gorgeous and striking climbers known, covered ail summer and autumn with huge trusses of large lilac blue flowers. Being deciduous in winter, it ought to be associated with other evergreen climbers, as would be Bignonia venusta. whose orange flowers will beautifully harmonize together.

Sollya heterophylla, Tasmania.............

A graceful climber, with willow-like foliage and pretty, tubular blue flowers. 
Stauntonia hexaphylla, China..............

Eiegant foliage; spikes of white fragrant flowers in spring.

**Stephanotis floribunda, Madagascar .........

Truly a noble plant, with glossy leaves and pure white flowers exquisitely fragrant.

*Stigmaphyllon ciliatum, Brazil.... ........

slender growing; leaves fringed; pretty yellow flowers shaped like some orchids.

*Tacsonia exoniensis, garden hybrid ...... Flowers large, crimson.

*TACSONIA IGNEA, South America......... Flowers fiery red.

*Tacsonia Jamesoni, Ecuador................ Flowers cherry red.

*Tacsonia mixta, South America............ Flowers light pink.

*Tacsonia mollissima, Ecuador .. .......... Flowers rosy pink.

*Tacsonia tubiflora, Chile................ Similar to preceding, but of deeper shade.

*Tacsonia Van Volxemi, New Grenada........ Flowers bright crimson, hanging from a very long wiry pedicel.

Nearly related to Passifloras, Tacsonias are among the most desirable climbers, for their freedom of gruwth aud profusion of their showy blossoms.

*TECOMA AUSTRALIS, Australia ........

Oue of the most vigorous climbers we have, foliage glossy, very variable, in young plauts resembling a finely cut fern; gradually increasing in size, so as to appear in time quite a different plant; flowers smali, creamy color dusted with red, in very thick bunches. Blooms here in early spring, and occasionally in other seasous. This is the same that goes under the name of Bignonia Manglesii in Southern Europe, and of Campsidium flicifolium and c. Valdivianum in California.

Tecoma grandiflora, China. . . . . . . . . .....

Tecoma grandiflora atrosanguinea...........

Both deciduous; first with orange, secoud with blood red flowers. 
*Tecoma jasminoides, Australia............\$

*Tecoma jasminoides alba magna . . . . . . . . . .

Evergrees, with glossy leaves and almost everblooming; first having white flowers with crimson throat; second pure white of larger size.

*Tecoma Mackenni, South Africa ...........

Exceedingly vigorous; làrge, pinkish flowers, in huge bunches.

**TELFAIRIA PEDATA, Zanzibar

Figures already under economic plants; sure to prove a first rate vine, tor its vigour and the beauty of its foliage and flowers.

*THUNBERGIA ELEGANS, garden origin ?. .

*Thunbergia fragrans, India . . . . . . . . . . .

l.arge, pure white; very fragrant.

*Thunbergia grandiflora, India

A great grower; flowers larger than the preceding, of beautiful blue color.

*Thunbergia Mysorensis, India.............

Known also as Hexacentris Mysorensis; a most vig. orous climber with rich glossy foliage; flowers scarlet and yellow in very long bunches; very showy and sure to become a general favorite for winter bloom. ing.

Trachelospermum jasminoides, Southern China.

Dark green foliage, literally covered with white fragrant flowers in spring; will stand several degrees of frost.

Tropaeolum, garden varieties............. .

Although strictly herbaceous, the common Nasturtium deserves registering here, having become half woody and run wild in Southern California, a splendid and inexpensive decoration of waste places and rubbish heaps. A variety witl double sweet-scented flowers is very remarkable and pretty.

Vinca major, Southern Europe.............

Vinca major fol. $\operatorname{var} \ldots \ldots \ldots \ldots \ldots \ldots \ldots \ldots$

The large periwinkle; trailing, with large blue flowers, most adapted for borders, rockeries and hanging baskets, more particularly the second with variegated leaves; standing well drought and frost.

*VITIS BAUDINIANA, Australia...........

Going also under the name of Cissus antarctica, evergreen, very vigorous, suitable to cover rocks, walls, ete. 
Vitis Coignetiae, Japan .............. .\$

An immense climber, reaching the tops of the loftiest trees; leaves roundish, very large; assuming the richest hues in the fall.

*VITIS GONGYLODES, Brazil .... .... ....

Very remarkable and strange looking, the tall, climbing stems, furnished with membranous wings, and bearing at the end of each shoot a long quadrangular woody tuber, that falls to the ground when ripe.

*VITIS HYPOGLAUCA, Australia. ........

Very elegant persistent foliage, dark green above, glaucous underneath.

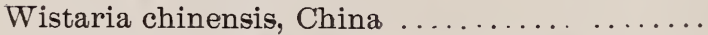

The common Wistaria or Glycine, familiar to everybody; doing very well on this coast.

Wistaria chinensis alba, China.

A pure white variety of the preceding, very choice.

WISTARIA FRUTESCENS, S o u t h e a s t e r $\mathrm{n}$

States

The American Wistaria, blooming later, but not less worthy to be grown in gardens.

Wistaria multijuga, Japan

...............

Similar iu habit $t_{1}$ ) W. (ehivensis; flowers of two shades of lilac, in bunches often over two feet loug.

Wistaria multijuga alba, Japan $\ldots \ldots \ldots \ldots \ldots$.... 50 to 100 Like the type, but flowers pure white.

\section{BULBOUS, TUBEROUS PERENIAL PLANTS.}

Bulbs differ from Tubers in having one central shoot with fleshy or leathery envelopes, while Tubers are of more irregular shape, often presenting several eyes, each originating a separate plant. The Onion is a good exemplification of a Bulb; the Potato of a Tuber. Both bulb and tuber are provisions for storing material necessary to the ensuing growth of the plant: and the colder or the more arid the 
country will be, the deeper they will be buried under the ground; a circumstance not to be forgotten when submitting them to artificial culture. Perennials do not possess a bulb nor a tuber, but are provided with more or less fleshy or woody roots, bunched together or running under ground, sometimes at considerable distance; the familiar alfalfa representing them well. As a general rule these three classes of plants, once established in suitable ground, will take care of themselves, needing only occasional fertilizing and thinning if too much overcrowded. Among them are.to be found the brightest ornaments of our gardens and the easiest plants to grow and to propagate. A condensed list of the most desirable is given below, without attempting a full enumeration of varieties, their number running into the thousands.

Acanthus mollis latifolius, Portugal.........\$

Broader foliage of a brighter $x$ reen than the following Acanthus spinosus, Southern Europe ... . . .

The classic Acanthus, remarkable for its bold foliage and huge spikes oî purple and white striped flowers.

Agapanthus umbellatus, South Africa.... ... .

The "African Lily"; large umbels of bright blue flow ers ou tall stems, during summer, in this country, attainiug very large size if in rich ground and liber ally watered.

Agathaea coelestis, South Africa . ........

Daisy-like flowers of the most exquisite sky blıe.

Allium neapolitanum, Southern Europe . .....

Large umbels of pure white, st:r-shaped flowers; one of the prettiest among winter flowering bulbs.

* Alonsoa incisifolia, Peru and Chile .... . . . . .

Pretty, cut foliage; hood-shaped flowers, ranging from scarlet to pure white.

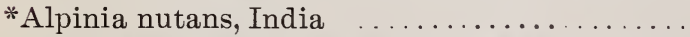

Foliage similar to a Canna; flowers large, in drooping bunches, pink and white, very pretty. Needs plenty of water.

Althaea ficifolia, South Europe ............

Large lemon yellow flowers, very show y. 
Amaryllis belladona, Cape of Good Hope .......\$

Flowers bright rose, in summer.

Anemone, garden varieties .

To be sure the most charming and showy flowers of early spring, every hue except yellow being folnd among them.

Anemone japonica. Japan

Anemone japonica alba, Japan..... .......

The first with rose colored, second with pure white flowers, standing well over the foliage; fall blooming, will prefer partial shade.

Anemopsis Californica, "yerba mansa" ......

Medicinal; flowers acrompanied by showy, white bructs; grows only in wet places

Aquilegia, garden varieties................

The popular "Columbine," of which so many varieties are grown at present, the prettiest being the result of crossings between species from colorado and from California

Armeria maritima, Southern Europe.

In this country called "thrift" and "sea pink"; quite dwarf and all covered with very pretty and long lasting, pink flowers.

Aster coeruleus, Michigan ................

Only about three feet high and very compact, in late summer appearing a feathery mass of sky blue flowers

*Begonia, garden varieties ...............

All the best supplied of the tuberous, ever blooming. and other types; doing admirably well on this coast, preferably with partial shade.

Bellis perennis, Europe .................

The humble and common daisy, single and double, of different shades, so much admired, and doing very well on nur coast.

*BOCCONIA FRUTESCENS, West Indies.... One of the handsomest and most impressive foliage plants; flowers inconspicuous, greenish, in very large terminal panicles.

Brodiaea, different Californian species ......... Ranging in color from pure white to sky blue and to orange scarlet, these native bulbs are well worth growing in gardens, and not at all difficult in hloom. 
Canna, garden varieties ................ 25 to 50

The very best supplied, of the tall growing, of the Crozy and other ypes; great favorites here where they are literally everblooming.

Celsia arcturus, Southern Europe........ . . .

Pretty. yellow flowers in spikes.

Centranthus ruber, Southern Europe ..... . .

Known also as Valerian; this and its white flowered form make large everblooming masses, growing in any soil and without irrigation.

Cerastium tomentosum, Southern Europe...... Carpeting the ground with a dense mass of greyish foliage, covered with pretfy, white flowers, in spring.

Chlorogalum pomeridianum, "Amole" .... ... Very large bulb; leaves loug, frilled; tali, branching pauicles of star-like, white fowers, opening only in the afternoon.

*Chrysanthemum frutescens, Canary Islands... The popular "Paris daisy," white and yellow, making splendid masses of bloom all the year round; one of the easiest plants to grow.

Chrysanthemum, garden varieties........... The very best supplied of the different sections of this most popular flower. Reduced rates for quantities.

Cineraria maritima, Southern Europe......... Feathery, silvery white leaves, and large trusses of yellow flowers, here produced all the year round.

Commelina coelestis, West Indies.... . . . . . . Another "Wandering Jew"; this bearing flowers of the most exquisite sky blue.

Cotyledon lanceolata, California............ Cotyledon laxa, California . . . ......... .

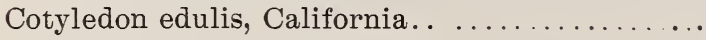

Cotyledon pulverulenta, California........... All eminently suited for rock and house plants, the last attaining over one foot in diameter.

*Crinum giganteum, West Africa .......... Growing over six feet high, with a stout trunk; flowers very freely produced, white, fragrant.

*Crinum Moorei, South Africa..... . ....... Not ${ }_{4}$ tall; flowers larger, of a beautiful shell pink 50 to 100 colo. 
*CRINUM YEMENSE, Arabia ... ... ...\$ 50 to 100 rlowers very large pure white, fragrant.

Crithmum maritimum, Europe.............

The curious looking "samphire"; bluish flechy foliage; flowers greenish; one of the very few plants not affected by salt water.

*Cyclamen, garden varieties ... .........

The very best supplied in different colors; will prefer partial shade.

*Cyrtanthus Mckenii, Natal...............

Bulbous and dwarf; very pretty, white flowers in winter.

*Dahlia arborea, Mexico................

*Dahlia imperialis, Mexico

Both of them building half woody stems several feet high, but dying to the ground out of our coast region; both much admired aud striking plants, with bold foliage and large, lily-shaped flowers, bright mauve in the first, pure white with crimson eye in the sec. ond; blooming in tie fall and early winter.

Dahlia, garden varieties ..............

Best varieties supplied of the different strains, Cac tus, Pompons, etc.

Datura meteloides, California ... ... .......

"Tolguacha" of the natives, growing prostrate on the ground; large, fragrant flowers, white tiuged bluish.

Delphinium cardinale, Southern California.....

No doubt the most striking and ornamental among Larkspurs, for its long spikes of fiery scarlet flowers, lasting in bluom several months; will show better if planted among low shrubs where its slender stems may find some support, such being its native habit of growth.

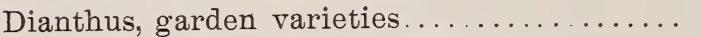

The very best carnations in separate colors.

*Dierama pulcherrimum, South Africa........

More known as Sparaxis pulcherrima; leaves erect, grass-like; flowers large, drooping, of a rich violet color, on tall, wiry stems.

*ECHIUM CANDICANS, Madeira............

*ECHIUM FASTUOSUM, Canary Islands..... 
*ECHIUM SIMPLEX, Canary Islands........ \$

All of them very decorative plants, with picturesque, more or less silvery foliage; bearing huge cylindrical spikes of flowers, blue in the first, reddish in secoud, pure white in third, on this last attaining several feet in length. Echiums are eminently suited for dry places, and need good drainage at their roots.

ELYMUS CONDENSATUS ............

A tall and strong growing grass; leaves broad, durk green: flower spikes quite conspicuous; highly decorative; will stand drought and cold.

*Erpetion reniforme, Australia..... .... . . "Australian violet," with pretty, purple and white violet looking flowers, standing well over the foliage.

*Freesia refracta alba, South Africa.... . ....

To be sure the most popular among winter blooming bulbs, for its exquisite perfume and chaste beauty.

Funkia grandiflora, Japan $\ldots . . \ldots \ldots \ldots$.. $2 \tilde{3}$

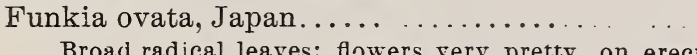
Broad radical leaves: flowers very pretty, on erect stems, white and fragrant in the first, bluish white in the second. Will prefer partial shade.

Galtonia candicans, South Africa ...........

Looking like a giant Hyacinth, tall spikes of bellshapec. pendulous, white flowers in summer.

Gaura Lindheimeri, Texas . .............

Tall, wiry stems bearing a succession of pretty, white flowers having the appearance of butterflies; excellent for bouquets; will thrive in any soil.

Gazania splendens, South Africa.... -....

Unsurpassed for bordering and carpeting slopes, etc., on account of the dazzlingness of its orange flowers.

Geum coccineum, Chile? ................. Elegant foliage; scarlet flowers; almost everblooming.

Gladiolus tristis, South Africa.............. Slender, grass-like leaves; tall spikes of pale lemon white flowers, not so showy as other kinds, but exqui sitely fragrant at night.

Gladiolus, garden varieties

Best varieties supplied of every strain of this most popular flower; which truly appears to have found a second hume in California. 
*Hedychium coronarium, India. . . . . . . \$ \$ 25

*HEDYCHIUM FLA VOSUM, India . ........ 25

*Hedychium Garderianum, India... ......... 20

Called by some people "Ginger plants," for a slight gingerly taste of their roots; tropical looking foliage, first having pure white, fragrant flowers, second light yellow, very fragrant, third orange red, scentless Howers.

Hemerocallis flava, Europe.............. . .

"Day lily," very hardy and free growing, large, lemon yellow flowers, sweetly fragrant, most of the year.

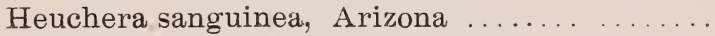

Leaves in a rosette. spreading, mottled whitish;graceful, erect spikes of the prettiest piuk flowers; in bloom for several months.

Hibiscus coccineus, Eastern Atlantic States..... Very finely cut foliage of reddish tinge; flowers large, scarlet, rivaling il: dazzlingness the tropical kinds.

*Hippeastrum aulicum, Brazil .............

*Hippeastrum Johnsoni, garden hybrid.......

*Hippeastrum vittatum, best garden varieties. . Popularly known as A maryllis; here bearing magnificent flowers at different seasons without requiring much care.

"Hunnemannia fumariaefolia, Mexico ........ . Going here under the name of Mexican Poppy, to'differentiate it from our California Poppy, Eschscholtzia, taller growing and more shrubby; flowers of very pleasant lemon yellow color, lasting several days in water.

*Imantophyllum miniatum, South Africa....... Leaves dark green, similar to the Amaryllis, flowers bright orange in large heads; winter blooming.

Iris alata, Portugal and Spain ............

Dwarf, winter blooming, blue, delicately fragrant; makes nice pot piants to have in bloom for Christmas.

IRIS AUREA, Himalaya... . . . . . . . . . . .

Tall; rich yellow flowers; very distinct.

IRIS CRETENSIS ALBA, Crete and Greece... 
IRIS CRETENSIS, Crete and Greece....... \$

Known also as I. stylosa; leares narrow, grass-like in deuse tufts; flowers pure white in the first, bluish purple in the second, appearing in the greatest profusion from October all through the winter. Very valuable for cut flowers; will not stand much frost, and will prefer partial shade.

Iris Florentina. Italy . . . . . . . . . . . .

Flowers large, pure white, fragrant, in early spring.

Iris foetidissima variegata, Europe... . . . . . .

Leaves beautifully striped white; flowers incon. spicuous; a very good house plant.

Iris germanica, South Europe .... . . . . . .

Size of preceding, but with wide range of colors, from white to deep purple, yellow and bronze. Both kinds are great bloomers, very showy, and will stand well intense cold and hears drought.

Iris laevigata, Japan.................

Flowers very large, almost flat wheu open, in endless variety, where all hues of blue, purple, slate, yellow and white are blended together. These are summer blooming, and will do better with liberal supply of water.

IRIS MADONNA, Arabia..... . . . . . . . .

Very vigorous and early bloomer; flowers large, of a heautiful blue color.

IRIS NOTHA, Caucasus to Kashmir. . . . . . . . The giant among true Irises; leaves broad, glaucous; flowers white and yellow on stalks several feet high, lasting very long in bloom; stands well drought; a striking plant altogether.

Iris pseudoacorus, Europe . . . . . . . . . . . .

Iris pseudoacorus variegata, . . . . . . . . .

Growing in wet places, even submerged in water;

flowers very large, bright yellow; almost everblooming; the variegated form is very graceful too.

Iris xiphium, Spain.................

Leaves few; flowers with narrowed and channelled segments, offering the prettiest combinations of bright blue and golden yellow; hlooming late in spring.

Dwarf, excellent for borders: flowers bright orange. in early spring. 
*Ixia, garden varieties . . . ... . . . ....\$

Taller growing; flowers iu erecl, taller spiki's, of the most brignt aud gay appearauce, almost every possible color beiug represented among them; will thrive in any kind of soil.

Kniphofia aloides, South Africa ..... ......

Best lite garden varieties.

KNIPHOFIA WOODII. Natal . . ...........

Kuown also as Tritomas, and bearing the commou name of "red poker plants," of very striking appearance; first haviug taller spikes of different shrdes of orange, second having pretty, lemon yellow flı.w. ers.

Lapeyrousia cruenta, South Africa ... . . . . .

Also called Anomatheca, and by some "scarlet Freesia"; flowers resembling the latter, but deprived of fragrance; fine for borders; also for growing in pots.

LEPTOSYNE MARITIMA, California........ Dwarf growing; flowers very large, of the brightest yellow, literally everblooming.

\section{Lilium}

The true Lily; all kinds supplied at proper season; detailed lists with prices mailed on anplication.

Linum perenne, Europe........... . .....

Only two feet high; numberless sky blue flowers, all the year round.

LIPPIA REPENS, Corsica and Western coast of

Italy

One of our own most valuable introductions. being the best substitute for lawn grass. Thrives in any soil, no matter how poor. Rapidly covers the ground with a very dense matting. The more trodden upon, the better it grows. Adopted in Southern Europe for lawn tennis grounds. Takes ten times less water than any lawn. Needs no mowing. Covered in summer with tiny pale lilac flowers. Can easily be taken out if needed.

Lobelia erinus, South Africa...............

Dwarf and compact, making the prettiest borders of different shades of blue; also white and pink. Con. tinuously in bloom here.

* Lycoris aurea, China..................

Blooming in the style of Amaryllis belladona; flow ers golden yellow in summer. 
*Mesembrianthemum acinaciforme, South Africa $\$ 500$ per 100 Extensive trailer; flowers large, magenta color.

* Mesembrianthemum aequilaterale, Cape; also

coasts of Australia, Chile and California. . 5 00 per 100 Similar in habit to the above; flowers yellow.

*MESEMBRIANTHEMUM AURANTIACUM,

Cape........................ 500 per 100 Dwarf and bushy; completely covered with large, dazzliug, sulphur yellow flowers.

*MESEMBRIANTHEMUM AUREUM, Cape. . 500 per 100 Like the precediug; flowers bright orange color.

*MESEMBRIANTHEMUM BLANDUM, Cape. 500 per 100 Similar in habit; fluwers white, shading to rose.

*Mesembrianthemum floribundum, Cape...... 5 00 per 100 Very low, and carpeting the ground; myriads of tiny, light lilac flowers.

*MESEMBRIANTHEMUM MUTABILE, Cape jo 00 per 100 A hout six iuches high, very compact, making dense masses of rich copper color of differant shades.

* Mesembrianthemum spectabile, Cape .... ... j00 per 100 Same habit as M. aurantiacuin, Howers of the bright est magenta color.

All above are really invaluable plants for bordering. covering slopes, and waste grounds; will need no water, but will stand only few degrees of cold. Many more species we have on trial; list furuished on application.

Mimulus moschatus, North California......... The popular "musk," mostly grown as pot and window plaut; pretty for borders in moist places.

Montbretia crocosmiaeflora, South Africa .....

Very popular here and very useful for summer blooming; numberless spikes of orange yel low flowers.

Moraea fimbriata, China................

The "fringed Iris": flowers light blue, with yellow blotches; an exquisite thing: early bloomer, will prefer some shade.

Moraea Robinsoniana, Lord Howe's Island......

The "wedäing Iris,"” a giant among its congeners, growing several feet high; flowers large, pure white, in summer; to be allowed plenty of water. 
**MUSA COCCINEA, Cochinchina .......\$

A dwarf Banana only a few feet high; bracts accom panying tine flowers of the brightest scarlet. Exceedingly showy.

* Musa rosacea, Mascarene Islands . ........

Dwarf also; growing in large clumps; bracts rosy purple.

Myosotis palustris, Europe . ..... ........

The very popular "forget me-not," of which we can furnish the finest garden varieties, in blue, white and pink. Doing admirably on this coast, and everblooming.

Narcissus, different species and varieties .....

The popular Daffodils, Jonquils, etc. Best choice supplied, at proper seasolis.

Nasturtium officinale, Europe ............ .

Water cress, valuable not only in the kitchen, but also for carpeting wet places, being constantly in bloom.

*Nierembergia rivularis, River Plate.........

Very pretty and low growing; covered all the year with salver shaped flowers, white, tinged bluish and yellow.

OENOTHERA CHEIRANTHIFOLIA, sea coast of Southern California ................

Thriving on shifting sands; very pretty, yellow flowers, keeping well in water.

OENOTHERA OVATA, California ........

Bearing the pretty name of "golden eggs," quite appropriate, appearing among the grass like a nest full of golden eggs; in early spring; will make very pretty borders.

Oenothera rosea, Mexico..............

The so called "Mexican Primrose," of different shades of pink, dwarf, everblooming.

Ornithogalum arabicum, Mediterranean basin. . Tall spikes of star-shaped, white flowers, quite showy.

*Othonna crassifolia, South Africa......... 500 per 100 Succulent and trailing, with minute rellow flowers; pretty for borders and for carpeting; also for hanging haskuts. 
Oxalis cernua, North Africa .............\$

Oxalis Deppei, Mexico ...................

Oxalis purpurea, South Africa. . ..........

First taller growing. with canary yellow flowers; second being $d$ warfer with purple pink flowers; the last not over three inches high, with large. rosy pink flowers, well set out by the admirable emerald green of its leaves; all of then excellent for borders, and thriving everywhere.

Paeonia, garden varieties..............

Select varieties of the herbacenus and ni the so. called "tree" Paeouies.

Pancratium maritimum, Southern Europe ..... Bulbous; leares bluish; flowers pure white, sweet scented, lastıng a long time in water. Will thrive right on the sea sand.

Penstemon, garden varieties................

Very showy and everblooming here; a good selection of an improved strain.

Petunia, garden varieties. ............... Single, double, friuged, giant; the best of this popular flower, so much improved by California growers.

*Phaius grandifolius, China ............. A noble looking terrestrial Orchid; quite easy to grow; tall, broad leaves; showy flowers, brownish and white, on tall spikes.

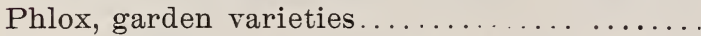

The very bestsupplied of this popular flower, so much improved of late years.

PLUMBAGO COERULEA; Chile............ Somewhat taller than the following; flowers deep blue.

Plumbago Larpentae, China .............

Dwarf; cobalt blue flowers, very pretty; prefers shade.

Polianthes tuberosa, Mexico...............

Well known "tuberose" so popular here, where it can be had in bloom in any month of the year.

Primula, garden varieties................

Best strains supplied of the different types; some of them doing well outaoors on this coast.

Pyrethrum partheniifolium aureum, garden origin...................... 500 per 100 The so-called "golden feather," so much used for bordering and carpeting. 
Ranunculus, garden varieties $\ldots . . . . \ldots . . \$$

All the best supplied in varied assortment. Can be had in bloom as early as Christmas.

*Richardia africana, South Africa .........

The "Calla Lily," attaining larger size here than in its native country. Quite an important item of export from (alifornia. For large quantities price on applicution.

*Richardia albo maculata, South Africa.......

The spotted Calla, very popular here; also a good house piant.

*RICHARDIA NELSONI, Natal ...........

Newly introduced; perhaps the best among yellow Callas that are coming to the front now.

ROMNEYA COULTERI, Southern California.

The much admired "Matilija Poppy"; half woody, but better treated as a perennial. Rather difficult to propagate and to establish, but after, growing and blooming quite freely, its large, frilled, pure white, fragrant flowers being one of the handsomest ornaments of gardens.

Ruellia formosa, Louisiana...............

Low growing and spreading; bright scarlet flowers in spikes, here produced all the year.

Rudbeckia laciniata, "golden glow," garden origin ...... . . . . ........

A striking plant altogether, growing here up to twelve feet, crowned with very large and double flowers of the most brilliant golden yellow color. Invaluable also for decorating.

Santolina chamaecyparissus, Southern Europe.. Dwarf and compact; greyish silvery all over; flowers smali, yellow; capital for borders, cemeteries, etc.

* Schizostylis coccinea, South Africa......... Bulbous; very showy scarlet flowers, in spikes, produced here from November through the winter.

Scilla campanulata, Southern Europe......... Spikes of charming, bell-shaped, light blue flowers, winter and early spring.

Scilla Clusii, Mediterranean region........... Dwarf, with broad leaves and dense spikes of azure blue flowers; early bloomer, very showy. 
*SEDUM FORMIOSANUM, Formosa ........

Newly introduced; low growing, and very distinct.

Sedum Sieboldii fol var., Japan..............

Very pretty, roundish glaucous leaves, with yellow blotch; flowers pink, in terminal panicles.

Sedum spectabile, Japan................. .

Growing about two feet; fleshy glaucous leaves; flowers pink in large heads; will grow in any soil, and make also beautiful house plants; much used for this purpose in Paris.

Sisyrinchium bellum .................

Sisyrinchium Californicum.... . .........

Iris looking dwarf plants, first having blue flowers, called "blue eyed"grass" second yellow flowers.

Sparaxis, garden varieties ...... .........

Closely related to Ixias, and like them native of South Africa. Best selection supplied in due season.

*Statice Halfordi, Teneriffe $\ldots . \ldots \ldots \ldots . . .$.

A beautiful plant, suffrutescent; very large, undulated leaves; enormous heads of everlasting blue flowers.

*STENOGLOTTIS LONGIFOLIA, Natal......

A dwarf terrestrial Orchid, upparently growing quite freely; very pretty, purple and white flowers in spikes.

Stenotaphrum americanum fol. var., Southern

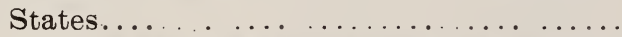

A very remarkable variegated grass, doing well in the shade of trees where little else would do; fine also for hanging baskets.

Sternbergia lutea, Southern Europe.........

Bulbous, large yellow flowers, appearing before the leaves in September.

*Strelitzia Reginae, South Africa.......... 100 to 250

The "bird of paradise flower," from its resemblance to a bird hrightly colored orange and blue. Growing very freely here, and literally blooming all the time.

TANACETUM BALSAMITA, Asia Minor .....

Rapidly making large clumps of broad, light green leaves highly aromatic. Common name in England "Costmary."

*TEEDIA LUCIDA, South Africa ..... . . . . .

Pink flowers in terminal heads all the rear. 
*Tigridia pavonia, Mexico ..............

One of the most showy bulbuus plants known; flowers several inches across, varying from snow white. through different shades of yellow, to the brightest scarlet. Easily grown, and a great bloomer, during summer.

Vallota purpurea, South Africa .... ........

Large Amaryllis-like flowers of blood red color, here blooming at different times of the year.

Verbena, garden varieties . .............

A good selection in separate colors. Reduced rates for quantities.

Viola, garden varieties ... .............

All the leading varieties supplied, at reduced rates for quantities.

VITTADINIA AUSTRALIS, Australia and

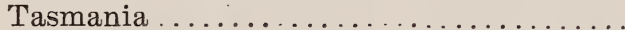

A charming dwarf piant; well suited for rockeries, borders and hanging baskets; covered with myriads of daisr-like, white flowers.

Watsonia angusta, South Africa ............

Watsonia Ardernei, South Africa. ... ........

Both magnificent bulbous plants, sure to become very popular when better known, first bearing tall spikes of fiery red, secoud snow white flowers, in spring: lasting a very loug time in water.

Zauschneria Californica, California...........

"California Fuchsia" as itis popularly called, its scarlet flowers being the brightest ornament of waysides and driest places, from July to the end of the year.

Zephyranthes candida, River Plate $\quad . . \ldots \ldots$.

Zephyrantes rosea, Cuba.................

Dwarf; pretty, Amaryllis-like flowers, snow white in the first, bright rose in the second; both charming for borders, aud also as por plants.

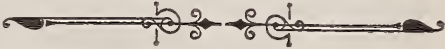




\section{Calífornía Natíve} Plants and Seeds

LARGE number of the most H remarkable and desirable Californian Plants will be found offered in the different sections of this Catalogue. We are in the best position to furnish any other that may be called for. Seeds also col. lected and furnished to order.

\section{Agrícultura1,}

forest and Garden

\section{Seeds th}

E have the very best facilities for supplying Seeds of every description, either raised in California or from other parts of the world, through reliable correspondents that we have procured in foreign countries. Prices quoted on application. 
Roses, Cactí,

rater Plants,

ferns, Orchíds

I AVING made arrangements

1 with the most reliable collectors and special growers, we are able to supply any of the above plants at the best rates.

Detailed lists and prices mailed free on application.

\section{Books and}

Periodicals

W are Agents for the leading publishing firms and in a general line can furnish at CATALOGUE PRICE every horticultural, agricultural and botanical Book and Periodical published anywhere.

Price quoted for any work wanted.

Please address all correspondence,

$$
\text { P. O. BOX 1500, }
$$

SANTA BARBara, Gal., U. S. A. 


\section{Cyclopedia of American Horticulture}

$T$ his great work comprises directions for the cultivation of horticultural crops. and original descriptions of all the species of Fruits, Vegetables, Flowers, and ornamental plants known to be in the market in the United States and Canada. .. $\quad . . \quad$..

By L. H. BAILEY, of Cornell University, assisted by WILHELM MILLER and many expert cultivators and Botanists.

In Four Quarto Volumes. Illustrated with orer 2000 Original Engravings.

THE MOST COMPREHENSIVE AND MOST UP-TO-DATE WORK EVER PUBLISHED ON HORTICULTURE. *

The Cyclopedia is to be completed in four handsome quarto rolumes, embracing about 2000 pages,

with more than that number of original

illustrations. It is carefully printed on specially made paper of a permanent character, and the work will

be completed within the year 1900 . $\therefore \quad \therefore$

Sold only by Subscription. Cost of each volume, clothbound, FIVE DOLLARS, free by mail.

Subscriptions received at the original cost, also by SOUTHERN CALIFORNIA ACCLIMATIZING ASSOCIATION, SANTA BARBARA, CAL., U. S. A. 


\section{DR. F. FRANCESCHI}

\section{Santa Barbara Eæotic flora}

\section{Being a Complete Review of Plants from Foreign \\ Countries Introduced in Southern \\ California up to 1894.}

CONTENTS

Clinıatic Peculiarities of

Santa Barbara

The Palms

The Bamboos

Decorative Plants

Fruit Bearing Trees

The Conifers

Evergreen Shade Trees
Deciduous Trees

Flowering Shrubs

Climbers

The Roses

Bulbous and Tuberous Rooted Plants.

Herbaceous Perennials

Orchids and Ferns

88 Pages, with Index, comprising over 600 Genera of Plants.

PIRTOE 35 CHNTE

FREF, BY MAIL FROM THE AU'THOR,

\section{DR. F. FRANCESCHI, Santa Barbara, Cal.}

".... There is no doubt of its value, and I presume the botanists and horticulturists of the country will fully appreciate it, and that there will be a great demand for it in the semitropical regious of the Uniter states."

J. STERLING MORTON, U. S. Secretary of Agriculture.

"....The work contains much useful information not to be found elsewhere, and wili be suggestive to those who wish to experiment with new plants."

THE EXAMINER, San Francisco.

".... It describes several hundred plants and is carefully indexed, so that it becomes in reality a manual of our most important exotics. Its cost-35 cents-is hardly an inta of its value to the plant iover."

PACIFIC RURAL PRESS, San Francisco.

“....This cleverly written work is dedicated to the ladies of Santa Barbara, and deserves, and no doubt will receire, the liberal support of all professionists, as well as of those that take an interest in botany."

THE SOUTHERN GARDEN, New Orlearis.

"....Iu the great scarcity of books we have on such matters, it ought to prove useful generally in the south."

THE AMERICAN GARDENING, New York.

"....The author being well qualified by reason of long training and experience gained during years of travel and observation in this class of work, the nomenclature is reliable, while his deductions and suggestions are practical and to the point.",

THE RURAL CALIFORNIAN, Los Angeles.

"....This careful handbook should serve both now and in the future to prove what has been doue, and what may yet be accomplished in acclimatizing plants in California."

THE GARDENER'S CHRONICLE, London. 